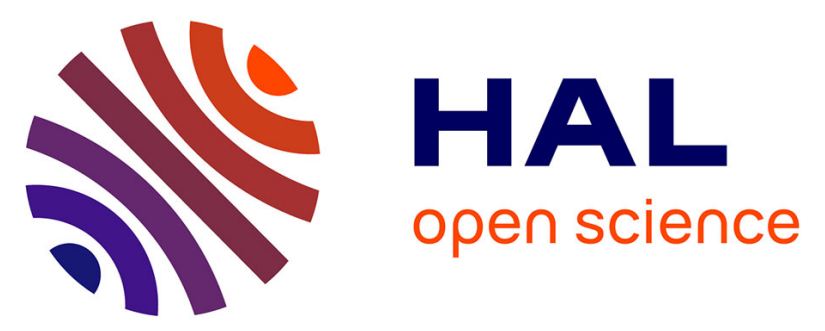

\title{
Evolution of K-rich magmas derived from a net veined lithospheric mantle in an ongoing extensional setting: Geochronology and geochemistry of Eocene and Miocene volcanic rocks from Eastern Pontides (Turkey)
}

Cem Yücel, Mehmet Arslan, Irfan Temizel, Emel Abdioğlu, Gilles Ruffet

\section{To cite this version:}

Cem Yücel, Mehmet Arslan, Irfan Temizel, Emel Abdioğlu, Gilles Ruffet. Evolution of K-rich magmas derived from a net veined lithospheric mantle in an ongoing extensional setting: Geochronology and geochemistry of Eocene and Miocene volcanic rocks from Eastern Pontides (Turkey). Gondwana Research, 2017, 45, pp.65-86. 10.1016/j.gr.2016.12.016 . insu-01462865

\section{HAL Id: insu-01462865 \\ https://hal-insu.archives-ouvertes.fr/insu-01462865}

Submitted on 9 Feb 2017

HAL is a multi-disciplinary open access archive for the deposit and dissemination of scientific research documents, whether they are published or not. The documents may come from teaching and research institutions in France or abroad, or from public or private research centers.
L'archive ouverte pluridisciplinaire HAL, est destinée au dépôt et à la diffusion de documents scientifiques de niveau recherche, publiés ou non, émanant des établissements d'enseignement et de recherche français ou étrangers, des laboratoires publics ou privés. 


\section{Accepted Manuscript}

Evolution of K-rich magmas derived from a net veined lithospheric mantle in an ongoing extensional setting: Geochronology and geochemistry of Eocene and Miocene volcanic rocks from Eastern Pontides (Turkey)

Cem Yücel, Mehmet Arslan, İrfan Temizel, Emel Abdioğlu, Gilles Ruffet

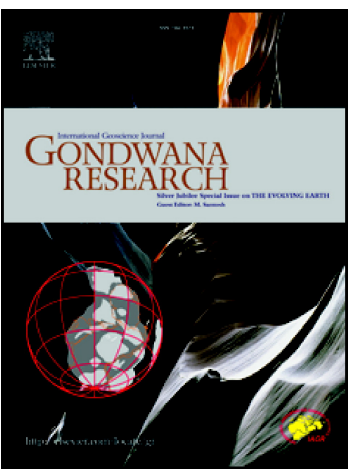

PII: S1342-937X(17)30060-6

DOI: doi: $10.1016 /$ j.gr.2016.12.016

Reference: GR 1739

To appear in:

Received date: 3 December 2015

Revised date: $\quad 27$ December 2016

Accepted date: $\quad 27$ December 2016

Please cite this article as: Cem Yücel, Mehmet Arslan, İrfan Temizel, Emel Abdioğlu, Gilles Ruffet, Evolution of K-rich magmas derived from a net veined lithospheric mantle in an ongoing extensional setting: Geochronology and geochemistry of Eocene and Miocene volcanic rocks from Eastern Pontides (Turkey). The address for the corresponding author was captured as affiliation for all authors. Please check if appropriate. $\operatorname{Gr}(2016)$, doi: 10.1016/j.gr.2016.12.016

This is a PDF file of an unedited manuscript that has been accepted for publication. As a service to our customers we are providing this early version of the manuscript. The manuscript will undergo copyediting, typesetting, and review of the resulting proof before it is published in its final form. Please note that during the production process errors may be discovered which could affect the content, and all legal disclaimers that apply to the journal pertain. 


\title{
Evolution of K-rich magmas derived from a net veined lithospheric mantle in an ongoing extensional setting: Geochronology and geochemistry of Eocene and Miocene volcanic rocks from Eastern Pontides (Turkey)
}

\author{
Cem Yücel ${ }^{*, 1}$, Mehmet Arslan², İrfan Temizel², Emel Abdioğlu ${ }^{2}$, Gilles Ruffet ${ }^{3,4}$ \\ ${ }^{1}$ Department of Mining Engineering, Gümüşhane University, TR-29000, Gümüşhane, Turkey \\ ${ }^{2}$ Department of Geological Engineering, Karadeniz Technical University, TR-61080, Trabzon, Turkey \\ ${ }^{3}$ CNRS (CNRS/INSU) UMR 6118, Géosciences Rennes, F-35042 Rennes Cedex, France \\ ${ }^{4}$ Université de Rennes 1, Géosciences Rennes, F-35042 Rennes Cedex, France
}

\begin{abstract}
The Eocene and Miocene volcanic rocks between the cities of Trabzon and Giresun in the Eastern Pontides (NE Turkey) erupted as mildly and moderately alkaline magmas ranging from silica-saturated to silica-undersaturated types. ${ }^{40} \mathrm{Ar}-{ }^{39} \mathrm{Ar}$ dating and petrochemical data reveal that the studied volcanic rocks are discriminated in two: Lutetian (Middle Eocene) mildly alkaline, (basaltic rocks: $45.31 \pm 0.18$ to $43.86 \pm 0.19$ Ma; trachytic rocks: $44.87 \pm 0.22$ to $41.32 \pm 0.12 \mathrm{Ma}$ ), and Messinian (Late Miocene) moderately alkaline volcanic rocks (tephrytic rocks: $6.05 \pm 0.06$ and $5.65 \pm 0.06 \mathrm{Ma}$ ). The trace and the rare earth element systematic, characterised by moderate light earth element (LREE)/heavy rare earth element (HREE) ratios in the Eocene basaltic and trachytic rocks, high LREE/HREE ratios in the Miocene tephrytic rocks, and different degrees of depletion in $\mathrm{Nb}$, Ta, Ti coupled with high $\mathrm{Th} / \mathrm{Yb}$ ratios, show that the parental magmas of the volcanic rocks were derived from mantle sources previously enriched by slab-derived fluids and subducted sediments. The $\mathrm{Sr}, \mathrm{Nd}$ and $\mathrm{Pb}$ isotopic composition of the Eocene and Miocene volcanic rocks support the presence of subduction-modified subcontinental lithospheric mantle. During the magma ascent in the crust, parental magmas of both the Eocene and Miocene volcanic rocks were mostly affected by fractional crystallisation rather than assimilation coupled with fractional crystallisation and mixing. The silica-undersaturated character of the Miocene tephrytic rocks could be attributed to assimilation of carbonate rocks within shallow-level magma chambers. The parental magmas of the Eocene volcanic rocks resulted from a relatively high melting degree of a net veined mantle and surrounding peridotites in the spinel stability field due to an increase in temperature, resulting from asthenospheric upwelling related to the extension of lithosphere subsequent to delamination. The parental magmas for the Miocene volcanic rocks resulted from a relatively low melting degree of a net veined mantle domain previously modified by metasomatic melts derived from a garnet peridotite source after decompression due to extensional tectonics, combined with strike-slip movement at a regional scale related to ongoing delamination.
\end{abstract}

Key words: alkaline volcanic rocks, ${ }^{40} \mathrm{Ar}-{ }^{39} \mathrm{Ar}$ dating, mantle metasomatism, carbonate assimilation, Eastern Pontides 


\section{Introduction}

Alkaline rocks constitute less than 1\% of all igneous rocks of the Earth's crust (Gill, 2010) and can be observed in various geodynamic environments, such as active plate margins (e.g. Indonesia; Varne, 1985; Stolz et al., 1990), intra-plate (e.g. East African rift; Rosenthal et al., 2009) and syn- to post-collisional settings (e.g. Italy, Conticelli et al., 2002, 2009a, 2009b; Gasperini et al., 2002). Besides, alkaline rocks are generally taken into consideration with their unusual mineralogy and distinct trace and rare earth element contents, generally explained by low-degree partial melting of a peridotitic source. They are also notable for their silica-undersaturated features leading to crystallisation of feldspathoid minerals instead of feldspars. These distinct features make interpretation of the origin and evolution of alkaline rocks very difficult, especially for those in subduction zones. Although the deeper part of the mantle is often believed to be a viable source for silica-undersaturated volcanic rocks based on geochemical (Hawkesworth and Vollmer, 1979; McKenzie and Bickle, 1988; Hawkesworth et al., 1990; Bradshaw et al., 1993) and thermal considerations (e.g. McKenzie 1989), the origin and processes leading to the formation of leucite and/or analcime-bearing potassic rocks in intra-plate and plate-margin tectonic settings, remain controversial (Conticelli and Peccerillo, 1992; Shaw, 1996; Edgar and Mitchell, 1997). Metasomatised oceanic or continental lithospheric mantle can be accepted as the alternative source for alkaline magmas (Sun and McDonough, 1989; Halliday et al., 1992, 1995; Niu and O'Hara, 2003; Workman et al., 2004; Pilet et al., 2005, 2008; Panter et al., 2006). The source enrichment can be explained via the addition of melts or fluids from altered oceanic crust and sediments through subduction (Chase, 1981; Hofman and White; 1982; Palacz and Saunders; 1986; Hart, 1988; Nakamura and Tatsumoto; 1988; Barling and Goldstein; 1990; Weaver, 1991; Chauvel et al., 1992). Experimental studies indicate that mantle peridotite including hydrous, incompatible element-rich net veins derived from subducted sediments is an alternative source for alkaline magmas (e.g. Foley, 1992; Mitchel, 1995). Kamafugitic magmas as an ultrapotassic variant of melilitic magmas are considered to be generated by mantle melting under high $X_{\mathrm{CO} 2}$ conditions even at low pressure (e.g. Edgar et al., 1980; Wendlandt and Egler, 1980a, 1980b; Arima and Edgar, 1983; Lloyd et al., 1985; Edgar, 1987; Stoppa and Schiazza., 2013, Conticelli et al., 2015). Supporting this idea, the capability of producing K-rich granitic or phonolitic melts from carbonated pelites at temperatures of $950-1070^{\circ} \mathrm{C}$ and high $P(2.4 \mathrm{GPa})$ was recently suggested by Thomsen and Schmidt (2008). Furthermore, the source of the most sodic alkaline rocks is generally viewed as convecting asthenosphere modified by enriched lithospheric mantle and crustal material (White and Hofmann, 1982; McKenzie and O’Nions, 1983; Hart, 1988).

Although there have been different scenarios proposed for the geodynamic evolution of the Eastern Pontides, a well preserved magmatic arc in NE Turkey (e.g. Şengör and Yilmaz 1981; Chorowicz et al., 1998; Bektaş et al., 1999, Eyüboğlu et al., 2011), most workers have reached a consensus on the northward subduction of the northern branch of Neo-Tethys beneath the Eurasian 
Plate along the İzmir-Ankara-Erzincan suture zone (IAES) (e.g. Ustaömer and Robertson, 1996; Rice et al., 2009; Dilek et al., 2010). Tertiary volcanics are observed on both sides of the IAES, implying that Eocene volcanism was post-collisional. Tertiary volcanic rocks occur both in the northern and southern parts of the Eastern Pontides (e.g., Arslan et al., 1997; Arslan and Aliyazıcıŏlu, 2001; Temizel and Arslan, 2009; Kaygusuz et al., 2011; Temizel et al., 2012; Arslan et al., 2013; Aslan et al., 2014). Post-collisional Middle Eocene volcanism that covers extensive areas from the Western to the Eastern Pontides was revealed by recent detailed studies (Robinson et al., 1995; Y1lmaz et al., 1997; Okay and Şahintürk ,1997; Arslan et al., 1997; Şen et al., 1998; Arslan and Aliyazıcıŏlu, 2001; Altherr et al., 2008; Keskin et al., 2008; Temizel and Arslan, 2009; Aslan, 2010; Kaygusuz et al., 2011; Temizel et al., 2012; Aydınçakır, 2012; Aydınçakır and Şen, 2013; Arslan et al., 2013; Aydınçakır, 2014; Temizal et al., 2016). Besides, narrowly extending Early Eocene (Karslı et al., 2010; Eyüboğlu et al., 2011) and Miocene volcanism were also identified in this area (Arslan et al., 2001; Aydın et al., 2008; Temizel et al., 2012; Yücel et al., 2012). Alkaline volcanic rocks in the Trabzon area derived from upper mantle and/or lower crust were first described by Arslan et al. (1997). Aydin et al. (2008) reported that enriched subcontinental lithospheric mantle can be the source of the Miocene alkaline volcanic rocks.

Although the aforomentioned studies on Tertiary volcanic rocks throughout the Eastern Pontides are mainly about geochemical and isotopic compositions, absolute age relationships, and the petrogenesis of these rocks, the processes responsible for generation of Middle Eocene and Late Miocene alkaline volcanism are still poorly explained. This study concerns the Eocene and Miocene volcanic rocks in the area between Trabzon and Giresun in the northern part of the Eastern Pontides (NE Turkey). Here, we present new ${ }^{40} \mathrm{Ar}-{ }^{39} \mathrm{Ar}$ ages, whole-rock major and trace element analyses, as well as $\mathrm{Sr}-\mathrm{Nd}-\mathrm{Pb}$ isotope data to understand the genesis of K-rich volcanism through an assessment of petrogenetic processes and their possible geodynamic significance.

\section{Geological outline and local stratigraphy}

The Eastern Pontides, in the central part of the Alpine-Himalayan orogenic belt, is of key importance to understand the tectono-magmatic evolution of the Pontides and Eastern Mediterranean. This orogenic belt lies along the İzmir-Ankara-Erzincan suture zone in NE Turkey (Fig. 1a). During the course of the Alpine orogeny (Laramian phase), the region was affected by the collision of the Tauride-Anatolide platform with the Pontides, which resulted in well-documented igneous records in the active margin of the Neo-Tethyan convergence system in Turkey (Şengör and Y1lmaz, 1981; Bozkurt and Mittwede, 2001). These tectono-magmatic episodes are discrete pulses with different geochemical compositions, as suggested by temporal and spatial records of the magmatic activity. Although there have been different interperations in the literature (e.g. Bektaş et al., 1995; Eyüboğlu et 
al., 2006), the Eastern Pontides are generally subdivided into northern and southern sub-domains with regards to their structural and lithological features (Özsayar et al., 1981; Okay and Şahintürk, 1997).

The northern part of the Eastern Pontides comprises Late Cretaceous, Middle Eocene, and Miocene units, whereas the southern part is widely dominated by pre-Late Cretaceous units (Arslan et al., 1997; Şen, 2007). The Hercynian basement of the Eastern Pontides consists of metamorphic rocks and granitic intrusions (Yılmaz, 1972; Çoğulu, 1975; Topuz et al., 2010; Ustaömer and Robertson, 2010; Kaygusuz et al., 2012; Kaygusuz et al., 2016). Jurassic volcanic and volcano-sedimentary rocks lie unconformably on the basement and mostly crop out in the southern part. Volcanic rocks, which are mainly tholeiitic in character, comprise basaltic, minor andesitic, and trachyandesitic lavas and their pyroclastic equivalents. Jurassic-Cretaceous neritic and pelagic carbonates conformably overlie Jurassic volcanic and volcano-sedimentary rocks. These carbonates are locally overlain unconformably by a Late Cretaceous series comprising sedimentary rocks in the southern part and volcanic rocks in the northern part. The Late Cretaceous volcanic rocks consist of tholeiitic to calcalkaline dacite, rhyolite, and less andesite, basalt, their pyroclastics and alkaline volcanic rocks (e.g., Aydınçakır, 2016). These units are intruded by Late Cretaceous granitoids (e.g., Kaygusuz et al., 2010). Eocene volcanic and volcaniclastic rocks overlie this Late Cretaceous series (Güven, 1993; Arslan and Aliyazıoğlu, 2001; Kaygusuz et al., 2011; Temizel et al., 2012; Arslan et al., 2013; Aslan et al., 2014; Temizel et al., 2016). During Paleocene-Early Eocene time, the Eastern Pontides were above sea level probably because of collision (Okay and Şahintürk, 1997; Boztuğ et al., 2004). Eocene volcanic and volcaniclastic rocks in the region are intruded by calc-alkaline granitoids of similar age (Arslan and Aslan, 2006; Karsl1 et al., 2012; Kaygusuz and Öztürk, 2015). Post-Eocene uplift and erosion brought clastic input into locally developed basins in the north (Korkmaz et al., 1995). From the end of Middle Eocene times, the region remained largely above sea level and has been affected by minor volcanism and terrigeneous sedimentation until the present (Okay and Şahintürk, 1997). Miocene magmatism of the Eastern Pontides was characterised by calc-alkaline to mildly alkaline volcanism (Şen et al., 1998; Aydın et al., 2008; Temizel et al., 2012; Aslan et al., 2014; Yücel et al., 2014a).

The studied Eocene and Miocene volcanic rocks from the Trabzon and Giresun areas in the northern part of the Eastern Pontides (Fig. 1b, c) have been previously considered as Eocene in aged ("Kabaköy Formation"; Güven, 1993). The volcanic rocks were separated into Trabzon and Tonya groups by Arslan et al. (1997). The volcanic rocks around the Trabzon area were attributed to Miocene times (Arslan et al., 2001; Aydın et al., 2008; Yücel et al., 2012) whereas those between Tonya and Giresun areas were ascribed to Eocene times (Yücel et al., 2012). The two temporal Tertiary volcanic groups, Eocene (e.g., Güven, 1993; Yücel et al., 2012) and Miocene (e.g., Arslan et al., 2001; Aydın et al., 2008; Yücel et al., 2012), are characterised by shallow subaqueous to subaerial-volcanic facies, respectively. The Eocene volcanic rocks are represented by volcaniclastics (breccias and tuffs), lavas (pillow lavas and basaltic lavas), and dike-sill-domes (basaltic dikes-sills, andesitic dikes-domes, and 
trachytic dikes). The Miocene volcanic rocks are represented by tuffs and breccias, brecciated lavas, and dikes and sills. The characteristics of these volcanic facies are given in detail by Yücel et al. (2014a). The studied Tertiary volcanic rocks are overlain unconformably by Miocene-Pliocene sedimentary rocks, saprolitic clay occurrences (Arslan et al., 2006), and Quaternary marine alluvium (Keskin et al., 2011; Fig. 1c).

\section{Petrography and mineralogy}

The studied Eocene and Miocene volcanic rocks are generally observed as volcaniclastics, lava flows, rarely dikes and domes. According to their volcanostratigraphy and facies features, Yücel et al (2014a) discriminated three suites as (1) Eocene basalt, trachybasalt, and basaltic trachyandesite (BTB) suite, which contains basaltic breccia and tuff, pillow lava, basaltic lava, and basaltic dike-sills; (2) Eocene trachyte and trachyandesite (TT) suite, which contains andesitic dikes, domes, and trachytic dikes; (3) Miocene basanite and tephrite (BT) suite, which contains foid-bearing breccia, foid-bearing brecciated lava, and foid-bearing dikes and sills. These discriminations and suite names are kept as Eocene basaltic and trachytic, and Miocene tephrytic rocks here, in order to reveal parental magma(s) and differentiative members in relation to their absolute ages. Petrographically, the common textural features of the Eocene basaltic rocks are microlitic porphyritic, hyalo-microlitic porphyritic, intersertal, glomeroporphyritic and fluidal. The main mineralogical composition of the volcanic rocks is clinopyroxene + plagioclase \pm olivine \pm brown mica \pm hornblende $\pm \mathrm{Fe}-\mathrm{Ti}$ oxide. The Eocene trachytic rocks contain phenocrysts of plagioclase \pm sanidine \pm brown mica \pm hornblende \pm clinopyroxene $+\mathrm{Fe}-\mathrm{Ti}$ oxide \pm quartz $(<5 \%)$, and show generally microgranular porphyritic, and rare trachytic, hypocrystalline, poikilitic, glomeroporphyritic and sieve textures. General textures of the Miocene tephrytic rocks are microgranular-porphyritic, hyalomicroporphyritic, glomeroporphyritic, microgranular, vesicular, and amygdaloidal. The main mineralogical composition is reflected by clinopyroxene \pm olivine \pm brown mica \pm hornblende \pm plagioclase \pm sanidine + analcime $+\mathrm{Fe}-\mathrm{Ti}$ oxide + apatite mineral assemblage. Beside the volcanic facies characteristics, the studied volcanic rocks have been reported in detail with the aspect of petrography and mineral chemistry by Yücel et al. (2014a).

\section{Analytical techniques}

The samples were collected from between Trabzon and Giresun in the Eastern Pontides (NE Turkey). They comprise mafic and intermediate volcanic rocks from the remnants of the Eocene and Miocene volcanic rocks composed mainly of volcaniclastics, lava flows, rarely dikes and domes. The most representative and freshest samples were selected for ${ }^{40} \mathrm{Ar}-{ }^{39} \mathrm{Ar}$ dating, whole-rock major oxides, trace and rare earth element (REE) and $\mathrm{Sr}-\mathrm{Nd}-\mathrm{Pb}$ isotope analyses. 


\subsection{Whole-rock major, trace and REEs}

The selected samples were first crushed using a jaw crusher $(0.1-1 \mathrm{~cm}$ in diameter), and then ground in a mild-steel mill to obtain rock powder to the grain size of $<200$ mesh. The whole-rock petrochemical analyses of 101 rock powders were undertaken at ACME analytical laboratories Ltd., Vancouver, Canada. Major and trace element compositions were determined via inductively coupled plasma atomic emission spectroscopy (ICP-AES) from pulp after $0.2 \mathrm{~g}$ samples of rock powder were fused with $1.5 \mathrm{~g} \mathrm{LiBO}_{2}$ and then dissolved in $100 \mathrm{ml}$ of $5 \% \mathrm{HNO}_{3}$. The REEs were analysed by inductively coupled mass spectrometry (ICP-MS) from pulp after $0.25 \mathrm{~g}$ samples of rock powder were dissolved using four acid digestions. Loss on ignition (LOI) was determined according to weight difference at $1000^{\circ} \mathrm{C}$. Detection limits range from $0.002-0.04 \mathrm{wt} \%$ for major oxides, $0.1-8 \mathrm{ppm}$ for trace elements and 0.01-0.3 ppm for REEs.

\section{2. ${ }^{40} \mathrm{Ar}-{ }^{39} \mathrm{Ar}$ dating}

Seventeen single groundmass fragments, five phlogopite and one sanidine crystal were analysed by the continuous laser probe $\left(\mathrm{CO}_{2}\right.$ Synrad $\left.{ }^{\circledR}\right)$ stepwise heating ${ }^{39} \mathrm{Ar}-{ }^{40} \mathrm{Ar}$ technique at Géosciences Rennes (France).

The samples were wrapped in $\mathrm{Al}$ foil to form small packets $(11 \times 11 \mathrm{~mm})$ that were stacked up to form columns within which packets of fluence monitors were inserted every 10 samples. Irradiation was performed at the McMaster reactor (Hamilton, Canada) and used 5C high flux location without Cd-shielding. It lasted $13.42 \mathrm{hr}\left(\mathrm{J} / \mathrm{h} \approx 3.71 \times 10^{-4} \mathrm{~h}^{-1}\right)$. The irradiation standard was sanidine TCRs (28.608 $\pm 0.033 \mathrm{Ma}$; according to Renne et al., 1998, 2010 and 2011). The sample arrangement in the irradiation allowed us to monitor the flux gradient with a precision of $\pm 0.2 \%$.

Heating steps were performed with a $\mathrm{CO}_{2}$ laser probe. All experiments concerned single grains. The experimental procedure was described by Ruffet et al. (1991, 1995). The five argon isotopes and the background baselines were measured in 11 cycles, in peak-jumping mode. Blanks were performed routinely every first or third/fourth run, and subtracted from subsequent sample gas fractions. All isotopic measurements are corrected for $\mathrm{K}, \mathrm{Ca}$ and $\mathrm{Cl}$ isotopic interferences, mass discrimination and atmospheric argon contamination.

Apparent age errors are plotted at the $2 \sigma$ level and do not include the errors on the ${ }^{40} \mathrm{Ar}^{*}{ }^{39} \mathrm{Ar}_{\mathrm{K}}$ ratio and age of the monitor and decay constant. The errors on the ${ }^{40} \mathrm{Ar}^{*} /{ }^{39} \mathrm{Ar}_{\mathrm{K}}$ ratio and age of the monitor and decay constant are included in the final calculation of the (pseudo-)plateau age error margins or for apparent ages individually cited. The analyses were performed on a Map $215^{\circledR}$ mass spectrometer. 
It is commonly considered that a plateau is obtained when calculated ${ }^{40} \mathrm{Ar}^{*} /{ }^{39} \mathrm{Ar}_{\mathrm{K}}$ ratios of at least three consecutive steps, comprising a minimum of $70 \%$ of the ${ }^{39} \mathrm{Ar}$ released, agree within 1 or $2 \sigma$ error bars with the weighted mean calculated ${ }^{40} \mathrm{Ar}^{*} /{ }^{39} \mathrm{Ar}_{\mathrm{K}}$ ratio of the plateau segment. Pseudo-plateau ages (PPA) can be defined with less than $70 \%$ of the ${ }^{39} \mathrm{Ar}$ released. All ages are displayed at the $1 \sigma$ level.

Analytical data and parameters used for calculations (isotopic ratios measured on $\mathrm{K}, \mathrm{Ca}$ and $\mathrm{Cl}$ pure salts; mass discrimination; atmospheric argon ratios; J parameter; decay constants) and reference sources are available in Supplementary Table 1.

\section{3. $\mathrm{Sr}-\mathrm{Nd}-\mathrm{Pb}$ isotopes}

$\mathrm{Sr}, \mathrm{Nd}$ and $\mathrm{Pb}$ isotope composition were determined for 19 samples. $\mathrm{Sr}$ and $\mathrm{Nd}$ isotopes were conducted at Géosciences Rennes (France) using thermal ionisation mass spectrometry (TIMS) on a Finnigan MAT-262 mass spectrometer. For $\mathrm{Sr}$ and $\mathrm{Nd}$ isotope analyses, approximately $50 \mathrm{mg}$ of whole-rock powder was first dissolved in $52 \% \mathrm{HF}$ for four days at $140^{\circ} \mathrm{C}$ on a hot plate, then dried, dissolved in $6 \mathrm{~N} \mathrm{HCl}$, dried again and finally dissolved in $2.5 \mathrm{~N} \mathrm{HCl}$. Sr and Nd were separated using conventional ion exchange techniques. Isotopic compositions were measured on a double Re filament configuration. Total blanks were Sr-Nd-Sm $<0.05 \mathrm{ng}$; uncertainties were $2 \%$ for ${ }^{87} \mathrm{Rb} /{ }^{86} \mathrm{Sr}$ ratio and $0.2 \%$ for ${ }^{147} \mathrm{Sm} /{ }^{144} \mathrm{Nd}$ ratio. $\mathrm{Sr}$ and $\mathrm{Nd}$ isotope ratios were normalised to NBS987 $\left({ }^{87} \mathrm{Sr} /{ }^{86} \mathrm{Sr}=0.710179 \pm 0.00001\right)$ and $\mathrm{JNd}_{\mathrm{i}}\left({ }^{143} \mathrm{Nd} /{ }^{144} \mathrm{Nd}=0.511958 \pm 0.000006\right.$, after Tanaka et al. $(2000)$ standard. The values measured for this standard were $0.710246 \pm 0.000010$ and $0.512076 \pm 0.000006$, respectively. $\mathrm{Pb}$ isotope analysis was carried out at Activation Laboratories Ltd. (Actlabs) at Ancaster, Ontario, Canada. $\mathrm{Pb}$ was separated using the ion-exchange technique with Bio- $\mathrm{Rad} 1 \mathrm{x} 8 . \mathrm{Pb}$ isotope compositions were analysed on a Finnigan MAT-261 multicollector mass spectrometer. The measured $\mathrm{Pb}$ isotope ratios were corrected for mass fractionation calculated from replicate measurements of $\mathrm{Pb}$ isotope composition in NBS SRM-982 standards. The external reproducibility of lead isotope ratios ${ }^{206} \mathrm{~Pb} /{ }^{204} \mathrm{~Pb}=0.1 \%,{ }^{207} \mathrm{~Pb} /{ }^{204} \mathrm{~Pb}=0.1 \%,{ }^{208} \mathrm{~Pb} /{ }^{204} \mathrm{~Pb}=0.2 \%$ on the $2 \sigma$ level was demonstrated through multiple analyses of standard BCR-1.

\section{Results}

5.1. ${ }^{40} \mathrm{Ar}-{ }^{39} \mathrm{Ar}$ dating

${ }^{40} \mathrm{Ar}-{ }^{39} \mathrm{Ar}$ laser probe analyses were performed both on mineral phases (phlogopite, sanidine) and on groundmass fragments. Basaltic rock experiments were exclusively performed on groundmass grains, while trachytic and tephrytic rock experiments concerned phologopite, sanidine and/or groundmass grains. The age spectra of samples from basaltic, trachytic and tephrytic rocks and the 
results of their inverse isochron calculations $\left({ }^{36} \mathrm{Ar} /{ }^{40} \mathrm{Ar}\right.$ versus ${ }^{39} \mathrm{Ar}_{\mathrm{K}} /{ }^{40} \mathrm{Ar}$; Turner, 1971; Roddick et al., 1980; Hanes et al., 1985) are presented in Supplementary Fig. 1. A summary of age determinations is given in Table 1. The great majority of the obtained age spectras have a flat pattern over more than $80 \%$ of the degassed ${ }^{39} \mathrm{Ar}_{\mathrm{K}}$. Few show low apparent ages in the low temperature steps, probably related to degassing of some weathering phases (e.g. 511 whole rock). Rarely higher but decreasing apparent ages (e.g. 777 whole rock) are probably related to some limited ${ }^{39} \mathrm{Ar}_{\mathrm{K}}$ recoil, occurring during irradiation, on phases degassing in the low-temperature domain. All these age spectra allow plateau age calculations that are, on the whole, validated by isochron calculations. Nevertheless, some wholerock experiments from basaltic rocks yield age spectra with slightly decreasing apparent ages from the low- to the intermediate- temperature steps with pseudo-plateau ages (PPA) in the high- temperature steps (e.g. whole rocks 301, 363 and 642). Such a pattern characterises ${ }^{39} \operatorname{Ar}_{\mathrm{K}}$ recoil with a broader extent than e.g. 777 whole rock. This is easy to recognise with isochron diagrams, as this recoil effect leads to a concave trajectory of successive degassing steps in the place of a simple straight line (e.g. 363 wholerock). Nevertheless, the high-temperature PPA provides rather good estimates of the true age of the analysed material, as suggested by their good agreement with results from isochron calculations. Eocene basaltic rock samples yielded ages between $44.21 \pm 0.18$ and $43.97 \pm 0.18 \mathrm{Ma}$ for pillow lavas, between $44.75 \pm 0.18$ and $44.15 \pm 0.17 \mathrm{Ma}$ for basaltic lavas and between $45.31 \pm 0.18$ and $43.86 \pm 0.19$ Ma for basaltic dikes and sills. Eocene trachytic rock samples yielded ages between $43.90 \pm 0.17 \mathrm{Ma}$ and $42.95 \pm 0.17 \mathrm{Ma}$ for andesitic dike and domes, and between $44.87 \pm 0.22 \mathrm{Ma}$ and $41.32 \pm 0.12$ Ma for trachytic dike. Some phlogopite/whole rock pairs from samples of trachytic rocks (e.g. 188, 318, 625) show slight age discrepancies that are within the range of analytical error. As phlogopite ages are systematically slightly older than whole rock ones, it could be seen that these minerals were disturbed by argon in excess (excess/inherited). Isochron calculations do not favour the excess argon hypothesis (cf calculated $\left({ }^{40} \mathrm{Ar} /{ }^{36} \mathrm{Ar}\right)_{\mathrm{i}}$ ratios, Supplementary Fig. 1) but cannot exclude the contention that phlogopites trapped some inherited argon, as these minerals are prone to such a process (e.g. Ruffet et al., 1997). Nevertheless, excess argon is more common in metamorphic rocks than in volcanic ones, since outgassing to the atmosphere is easier. It would probably be more sensible viewing a weathering effect disturbing analysed groundmass grains (and K-feldspars, cf. sanidine 188), as suggested by the low calculated $\left({ }^{40} \mathrm{Ar} /{ }^{36} \mathrm{Ar}\right)_{\mathrm{i}}$ ratios (inverse isochron calculations for whole rock grains $188,318,625)$, lower than the atmospheric ratio (298.56 \pm 0.31 ; Lee et al., 2006).

It is worth noting that the frequency diagrams of apparent ages and plateau or pseudo-plateau ages of samples from Eocene basaltic and trachytic rocks display two slightly distinct frequency peaks, at $\sim 44.7 \mathrm{Ma}$ and $\sim 43.8 \mathrm{Ma}$, suggesting that basaltic rocks could precede trachytic rocks for $\sim 1$ Ma (Fig. 2).

The youngest ages were obtained from samples of Miocene tephrytic rocks with plateau ages in the range of $6.05 \pm 0.06 \mathrm{Ma}$ for foid-bearing brecciated lava, $5.87 \pm 0.06 \mathrm{Ma}$ for foid-bearing dike and sill, and $5.65 \pm 0.06 \mathrm{Ma}$ for cognate inclusion. 


\subsection{Major and trace element geochemistry}

The major and trace element compositions of the studied Eocene and Miocene volcanic rocks are presented in Supplementary Table 2. The TAS (total alkali versus silica) diagram of Le Bas et al. (1986) was used to classify the studied rocks and to determine magma series (Fig. 3a). While Eocene basaltic rocks have a mafic composition, the trachytic rocks present an intermediate character with a higher $\mathrm{SiO}_{2}(55.6-63.8$ wt. \%) content. The Eocene volcanic rocks display predominantly mildly alkaline affinities, whereas the Miocene teprytic rocks show moderately alkaline affinity (Yücel et al, 2014a). The studied rocks were also checked through the classification diagram of Hastie et al. (2007) using less mobile elements such as Th and Co, because the LOI (0.7-5.7 wt. \% for basaltic, 1.1-5.5 wt. $\%$ for trachytic and 5.2-9.9 wt. \% for tephrytic rocks) values of several samples were rather high (Supplementary Table 2). The relatively high LOI contents of the Miocene tephrytic rocks are mostly related to alteration to low-temperature phases (e.g., analcime from leucite; Yücel et al., 2014b), the presence of hydrous phases such as phlogopite, and the minor amount of secondary minerals such as zeolites. In this diagram, while the Eocene basaltic rocks lie mainly in the field of calc-alkaline, high$\mathrm{K}$ and shoshonitic transitional basalts, basaltic andesites and andesites, the trachytic rocks plot in high$\mathrm{K}$ and shoshonitic basaltic andesite/andesite and dacite/rhyolite fields, except for one sample. The Miocene tephrytic rocks with a high-K and shoshonitic character plot into the basalt, basaltic andesite and andesite fields (Fig. 3b). The Eocene volcanic rocks are potassic $\left(\mathrm{K}_{2} \mathrm{O} / \mathrm{Na}_{2} \mathrm{O}=0.7-1.5\right.$ for basaltic rocks and 1.1-2.4 for trachytic rocks) and silica-saturated $\left(\mathrm{SiO}_{2}=44.9-56.8 \mathrm{wt}\right.$. \% for basaltic rocks and 55.6-63.8 wt. \% for trachytic rocks), whereas the Miocene tephrytic rocks are sodic-potassic $\left(\mathrm{K}_{2} \mathrm{O} / \mathrm{Na}_{2} \mathrm{O}=0.2-0.7\right)$ and silica-undersaturated $\left(\mathrm{SiO}_{2}=42.0-48.5\right.$ wt. \%), as indicated by $\Delta \mathrm{Q}$ versus $\mathrm{K}_{2} \mathrm{O} / \mathrm{Na}_{2} \mathrm{O}$ diagram (Fig. 3c) of Peccerillo (2002, 2003). In the AFM diagram (Fig. 4d), both Eocene and Miocene volcanic rocks generally follow the calc-alkaline and shoshonitic trajectories determined by Wimmenauer (1985) with their low $\mathrm{FeO}^{*}$. Using the $\mathrm{CaO}$ versus $\mathrm{Al}_{2} \mathrm{O}_{3}$ and $\mathrm{MgO}$ diagrams of Foley (1987) prepared for classification of alkaline rocks, most of the samples lie within the Roman province (plagioleucitite) field, except for some samples from Eocene trachytic rocks, reflecting an intermediate character and some samples with high $\mathrm{MgO}$ and low $\mathrm{Al}_{2} \mathrm{O}_{3}$ contents from Eocene basaltic rocks (Fig. $3 e, f)$.

In the Harker diagrams (Fig. 4, Supplementary Fig. 2), both the Eocene basaltic and trachytic rocks and the Miocene tephrytic rocks present similar variations. For the Eocene volcanic rocks, $\mathrm{TiO}_{2}$, $\mathrm{Fe}_{2} \mathrm{O}_{3}{ }^{*}, \mathrm{CaO}, \mathrm{MgO}, \mathrm{Ni}, \mathrm{Sr}$ and $\mathrm{Co}$ are negatively correlated; whereas $\mathrm{K}_{2} \mathrm{O}, \mathrm{Na}_{2} \mathrm{O}$, Th and $\mathrm{Rb}$ are positively correlated with $\mathrm{SiO}_{2}$ when $\mathrm{P}_{2} \mathrm{O}_{5}, \mathrm{Al}_{2} \mathrm{O}_{3}, \mathrm{Hf}, \mathrm{Zr}, \mathrm{Nb}$ and Ta show curvilinear behaviours. The Miocene tephrytic rocks do not exhibit as smooth a correlation as the Eocene volcanic rocks. $\mathrm{P}_{2} \mathrm{O}_{5}$, $\mathrm{MnO}, \mathrm{Fe}_{2} \mathrm{O}_{3}{ }^{*}, \mathrm{CaO}, \mathrm{MgO}, \mathrm{Sr}$, Ni and Co decrease while $\mathrm{TiO}_{2}, \mathrm{Na}_{2} \mathrm{O}, \mathrm{K}_{2} \mathrm{O}, \mathrm{Ba}, \mathrm{Hf}, \mathrm{Rb}, \mathrm{Zr}, \mathrm{Nb}$ and $\mathrm{Ta}$ show positive curvilinear and scattered behaviour with increasing $\mathrm{SiO}_{2}$. 
In primitive mantle-normalised (Sun and McDonough, 1989) multi-element diagrams (Fig. 5), the Eocene basaltic and trachytic rocks display broadly similar patterns characterised by enrichment in large-ion lithophile elements (LILEs; $\mathrm{Sr}, \mathrm{K}_{2} \mathrm{O}, \mathrm{Ba}, \mathrm{Rb}$ ), and $\mathrm{Th}$ and $\mathrm{Ce}$ and depletion in some high field strength elements (HFSEs; $\mathrm{Zr}, \mathrm{TiO}_{2}, \mathrm{Y}, \mathrm{Nb}, \mathrm{Ta}$ ). The Miocene tephrytic rocks have geochemical characteristics similar to those of the Eocene volcanic rocks. Although all volcanic rocks display typical subduction zone signatures (viz. depletions of $\mathrm{Nb}$, $\mathrm{Ta}$ and $\mathrm{TiO}_{2}$ ) the differences in subduction signature between Eocene and Miocene volcanic rocks draw attention. Enrichment in $\mathrm{Sr}, \mathrm{Ba}, \mathrm{Th}, \mathrm{Ce}$ and $\mathrm{P}_{2} \mathrm{O}_{5}$ for the Miocene tephrytic rocks is more sizeable than that of the Eocene volcanic rocks. Depletion of $\mathrm{P}_{2} \mathrm{O}_{5}$ and $\mathrm{TiO}_{2}$ in some trachyte samples from the Eocene trachytic rocks is more significant than for other volcanic rocks. The studied volcanic rocks present fractionated rare earth element (REE) patterns in chondrite-normalised REE plots. The Miocene tephrytic rocks are characterised by steep light rare earth element (LREE) patterns relative to heavy rare earth elements (HREEs). Despite similar REE patterns, Eocene basaltic and trachytic rocks exhibit less pronounced LREE enrichment than Miocene tephrytic rocks. The enrichment in LREE (La=21-91, 35-113, 220452) and HREE ( $\mathrm{Yb}=3-10,7-14,5-9)$ for Eocene basaltic and and Miocene tephrytic rocks resulted in $\mathrm{La}_{N} / \mathrm{Lu}_{\mathrm{N}}$ ratios ranging from 5.55-10.76, 4.65-11.64 and 36-69, respectively.

\section{3. $\mathrm{Sr}, \mathrm{Nd}$ and $\mathrm{Pb}$ isotope geochemistry}

$\mathrm{Sr}-, \mathrm{Nd}-$ and $\mathrm{Pb}-$ isotope ratios of the studied volcanic rocks are presented in Tables 2 and 3. The initial ratio of $\mathrm{Sr}$ and $\mathrm{Nd}$ isotopes was calculated using ${ }^{40} \mathrm{Ar}-{ }^{39} \mathrm{Ar}$ ages. Less evolved samples from the Eocene basaltic and trachytic rocks are characterised by initial ${ }^{87} \mathrm{Sr} /{ }^{86} \mathrm{Sr}$ ratios ranging between 0.70389-0.70448 and between 0.70408-0.70425, respectively. The Miocene tephrytic rocks display more radiogenic initial ${ }^{87} \mathrm{Sr} /{ }^{86} \mathrm{Sr}$ ratios, between $0.70518-0.70536$. On the other hand, scattering of radiogenic ${ }^{143} \mathrm{Nd} /{ }^{144} \mathrm{Nd}$ ratios of Eocene and Miocene volcanic rocks is limited, varying from 0.51268 $0.51279\left(\varepsilon \mathrm{Nd}_{\mathrm{i}}:+1.61\right.$ to +3.75$)$ for basaltic rocks, $0.51270-0.51275\left(\varepsilon \mathrm{Nd}_{\mathrm{i}}:+1.84\right.$ to +2.81$)$ for trachytic rocks and $0.51267-0.51269\left(\varepsilon \mathrm{Nd}_{\mathrm{i}}:+0.61\right.$ to +1.08$)$ for the tephrytic rocks. Within the $\left({ }^{87} \mathrm{Sr} /{ }^{86} \mathrm{Sr}\right)_{\mathrm{i}}$ versus $\left({ }^{143} \mathrm{Nd} /{ }^{144} \mathrm{Nd}\right)_{\mathrm{i}}$ correlation diagram, basaltic and trachytic rocks show less radiogenic Sr isotopic ratios compared to BSE, while the tephrytic rocks plot in partly Sr-enriched quadrant close to mantle array (Fig. 6a). Thus, the basaltic and trachytic rocks have isotopic similarities with the Ulubey (Ordu; Temizel et al., 2012) and Borçka (Artvin; Aydınçakır and Şen, 2013) volcanic rocks when tephrytic rocks exhibit similarities with Torul (Gümüşhane; Kaygusuz et al., 2011) and the Eastern Pontides Southern Part Eocene volcanic rocks (Arslan et al., 2013).

The lead isotope ratios exhibit narrow ranges e.g., ${ }^{206} \mathrm{~Pb} /{ }^{204} \mathrm{~Pb}=18.72-18.79$, ${ }^{207} \mathrm{~Pb} /{ }^{204} \mathrm{~Pb}=15.63-15.67,{ }^{208} \mathrm{~Pb} /{ }^{204} \mathrm{~Pb}=38.79-38.92$ for the basaltic rocks, ${ }^{206} \mathrm{~Pb} /{ }^{204} \mathrm{~Pb}=18.78-18.80$, ${ }^{207} \mathrm{~Pb} /{ }^{204} \mathrm{~Pb}=15.64-15.67,{ }^{208} \mathrm{~Pb} /{ }^{204} \mathrm{~Pb}=38.87-38.97$ for the trachytic rocks and ${ }^{206} \mathrm{~Pb} /{ }^{204} \mathrm{~Pb}=18.89$ $18.95,{ }^{207} \mathrm{~Pb} /{ }^{204} \mathrm{~Pb}=15.66-15.68,{ }^{208} \mathrm{~Pb} /{ }^{204} \mathrm{~Pb}=38.94-39.06$ for the tephrytic rocks. The Miocene 
tephrytic rocks have higher radiogenic lead isotope compositions than those of the Eocene volcanic rocks; all plot above the Northern Hemisphere Reference Line (NHRL; Hart, 1984) with relatively enriched ${ }^{207} \mathrm{~Pb} /{ }^{204} \mathrm{~Pb}$ ratios. The isotopic budget of the Eocene basaltic and trachytic rocks presents a close relationship with the Eastern Pontides Southern part Eocene volcanic rocks, whereas the Miocene tephrytic rocks exhibite similarities with the Late Cretaceous Everek Hanları volcanic rocks (Fig. 6b, c). Furthermore, $\Delta 7 / 4 \mathrm{~Pb}$ of the studied volcanic rocks ranges between 52.41-3.30 for basaltic rocks, 52.53-62.14 for trachytic rocks, $46.94-52.53$ for tephrytic rocks, when $\Delta 8 / 4 \mathrm{~Pb}$ ranges between $10.68-14.69,11.04-14.45,11.81-13.53$, respectively.

\section{Discussion}

The narrow range of isotopic composition and the large geochemical variations makes the interpretation of the origin and evolution of the volcanic rocks complicated, especially in collisional and post-collisional tectonic settings. The Tertiary volcanic units of the Eastern Pontides orogenic belt have been examined in terms of geochemical and isotopic characteristics by various studies (e.g., Arslan et al., 1997; Arslan and Aliyazıcıoğlu, 2001; Arslan et al., 2002; Temizel and Arslan, 2008; Temizel and Arslan, 2009; Kaygusuz et al., 2011; Temizel et al., 2012; Arslan et al., 2013; Temizel et al., 2016). Nevertheless, petrological and geodynamical investigations of the K-rich magmatism maintain their importance, and remain unsolved. In this section, the nature of mantle source and mineralogy and the degree of partial melting will be first discussed; then, we will turn to magma chamber processes such as fractional crystallisation (FC), assimilation coupled with fractional crystallisation (AFC) and magma mixing actualised at crustal magma chambers. This will allow for a discussion of the geodynamic evolution of K-rich Tertiary magmatism at a regional scale.

\subsection{Fractional crystallisation}

Low $\mathrm{SiO}_{2}(<52 \%$ wt.) and high $\mathrm{MgO}(>6 \%$ wt.) contents as well as an $\mathrm{Mg}$ number $(\mathrm{Mg \# )}>$ 65 with high $\mathrm{Ni}$ and $\mathrm{Cr}$ contents (generally above $100 \mathrm{ppm}$ ) characterise near-primitive volcanic rocks (e.g., Frey et al., 1978). The studied Eocene and Miocene volcanic rocks are quite different, with low Mg\# (16.6-55.9 for basaltic rocks, 5.4-37 for trachytic rocks and 23.4-44.6 for tephrytic rocks), generally low $\mathrm{Ni}$ (0.7-143 ppm for basaltic rocks, 0.2-16.2 ppm for trachytic rocks and 3.7-31.3 ppm for tephrytic rocks) and $\mathrm{Cr}$ (1.3-72.2 ppm for basaltic rocks, 1.4-4.2 ppm for trachytic rocks and 1.4$13.2 \mathrm{ppm}$ for tephrytic rocks) contents. The Eocene basaltic and trachytic rocks form consecutive trends, but the basaltic rocks, within discrimination diagrams (Figs. 3, 4 and Supplementary Fig. 2), appear to be more primitive compared to the trachytic rocks. Moreover, the overlap between basaltic and trachytic rocks ranging from $46.75-58.54 \mathrm{SiO}_{2}$ wt. $\%$ and observed consecutive trends mentioned 
above may indicate fractionation from a common magma composition. The more silica-rich trachytic rocks were evolved from magmas of more primitive basaltic rocks.

Valuable information about magmatic processes such as fractional crystallisation, assimilation and contamination that control the magma differentiation and its evolution from a primitive nature can be obtained through analyses of the trends of major and trace elements. The observed correlations in the Harker diagrams for Eocene and Miocene volcanic rocks probably reflect the significant role of fractional crystallisation processes during their evolution. The decrease in $\mathrm{MgO}, \mathrm{Fe}_{2} \mathrm{O}_{3}{ }^{*}, \mathrm{Co}$ and $\mathrm{Ni}$ with increasing $\mathrm{SiO}_{2}$ is probably related to olivine fractionation. The $\mathrm{CaO}$ and $\mathrm{MgO}$ decrease with increasing $\mathrm{SiO}_{2}$ reflects clinopyroxene fractionation. The negative trends in $\mathrm{Fe}_{2} \mathrm{O}_{3}{ }^{*}, \mathrm{TiO}_{2}$ and $\mathrm{MgO}$ may be related to fractionation of $\mathrm{Fe}-\mathrm{Ti}$ oxides, whereas negative $\mathrm{CaO}$ correlation parallel to $\mathrm{Sr}$ and negative $\mathrm{K}_{2} \mathrm{O}$ and $\mathrm{Na}_{2} \mathrm{O}$ trends with increasing $\mathrm{SiO}_{2}$ are probably linked to plagioclase, phologopite and K-feldspar joined fractionations. Negative $\mathrm{Nb}, \mathrm{Rb}, \mathrm{Ba}$ or negative $\mathrm{P}_{2} \mathrm{O}_{5}$ correlations with increasing $\mathrm{SiO}_{2}$ probably result from phlolopite and apatite fractionations, respectively.

The consequent enrichment in LREEs with respect to MREEs and HREEs of the Eocene and Miocene volcanic rocks results in upward concave patterns in the REE diagrams (Fig. 5). MREEs are strongly partitioned, especially in amphibole, which suggests that amphibole and clinopyroxene are part of the fractionated mafic phases (e.g. Gill, 1981; Thompson et al., 1984; Green and Pearson, 1985; Romick, 1987; Thirlwall et al., 1994). The lack of a sizeable Eu anomaly $\left(\mathrm{Eu}_{\mathrm{N}} / \mathrm{Eu}^{*}=0.81-1.01\right.$ for basaltic rocks, $0.81-1.00$ for trachytic rocks and $0.88-0.96$ for tephrytic rocks), except for three samples from the trachytic rocks $\left(\mathrm{Eu}_{N} / \mathrm{Eu}^{*}=0.47-0.54\right)$, shows that plagioclase is not a dominant silicate phase during fractional crystallisation.

To model fractional crystallisation processes (Fig. 7), $\mathrm{Sc}$ and $\mathrm{Rb}$ have been selected for Eocene basaltic rocks, $\mathrm{Sr}$ and Dy for Eocene trachytic rocks, and $\mathrm{Sc}$ and $\mathrm{Nb}$ for Miocene tephrytic rocks. $\mathrm{Rb}$ and $\mathrm{Nb}$ are strongly incompatible for mineral phases crystallising from magmas with basic compositions. Sc is highly partitioned into amphibole, clinopyroxene and biotite, but not into olivine and plagioclase. Sr, strongly partitioned in plagioclase, exhibits compatible behaviour during fractional crystallisation processes for magmas with intermediate compositions. Although Dy is strongly partitioned in hydrous mafic mineral phases such as amphibole, it generally comes into prominence with incompatible character for intermediate magma compositions. The $\mathrm{K}_{\mathrm{d}}$ values of $\mathrm{Rb}$, $\mathrm{Sc}, \mathrm{Sr}, \mathrm{Nb}, \mathrm{Dr}$ for amphibole, plagioclase, clinopyroxene, olivine, biotite and sanidine are given in Table 4.

The Rayleigh fractional crystallisation vectors of the Eocene basaltic and trachytic rocks and the Miocene tephrytic rocks have been modelled using Keskin (2002)'s FC modeller program. Data distributed on FC modelling diagrams suggest that the basaltic rocks follow vectors 2 and 3 (Fig. 7a). Acording to the modelled vectors of the fractionating mineral assemblage, clinopyroxene and plagioclase are the dominant phases $(\sim 40-50 \% \mathrm{cpx}$ and $\sim 50 \% \mathrm{pl})$; a minor amount of olivine $(\sim 10 \%$ ol) accompanies these assemblages. As can be seen in Fig. 7b, trachytic rocks, intermediate in 
character, follow predominantly vector 4 , which corresponds to plagioclase ( 55\%), amphibole $(\sim 30 \%)$ and minor amounts of clinopyroxene, biotite and sanidine ( $\sim 5 \%, \sim 5 \%$ and $\sim 5 \%$ respectively). Tephrytic rocks which may have evolved by fractional crystallisation from a basic magma, following vectors 2 and 3 (Fig. 7c), which correspond predominantly to clinopyroxene ( 70-80\%), but also to olivine and a minor amount of plagioclase ( $10-30 \%$ and $\sim 10 \%$ respectively). In light of the data obtained from geochemical variations and FC modelling, clinopyroxene is the dominant mineral as the fractionating phase for basaltic and tephrytic rocks, whereas plagioclase is the main one for the trachytic rocks. Other mineral phases accompanied them in minor amounts. These results are consistent with the detailed petrographic observations reported by Yücel et al. (2014a) for the studied volcanic rocks.

\subsection{Crustal assimilation}

The phenomenon of basaltic magma(s), passing through the thickened crust and staying in magma chambers located at different crustal levels, favours the possibility of crustal assimilation that has an impact upon isotopic and incompatible trace element compositions. The emplacement and stratigraphical features of the studied volcanic rocks reveal a paleoenvironment characterised by a long-term trend of decreasing shallow marine influence from the Middle Eocene to the Miocene periods (Yücel et al., 2014a). Thus, the potential effect of sea water alteration is another phenomenon that needs to be taken into consideration.

The $\mathrm{Zr} / \mathrm{Hf}$ ratios of primitive mantle and continental crust are $\sim 36.3$ and $\sim 11.0$, respectively. The basaltic $(\mathrm{Zr} / \mathrm{Hf}=26.5-41.9)$ and trachytic $(\mathrm{Zr} / \mathrm{Hf}=31.0-43.0)$ rocks have ratios similar to primitive mantle, whereas tephrytic rocks are characterised by a higher range $(\mathrm{Zr} / \mathrm{Hf}=39.5-57.9)$. The three groups are far beyond continental crust $\mathrm{Zr} / \mathrm{Hf}$ ratio. The Th/Ce $(0.05-0.24$ for basaltic, $0.13-0.34$ for trachytic and $0.06-0.17$ for tephrytic rocks), and $\mathrm{Th} / \mathrm{La}(0.12-0.46$, for basaltic $0.30-0.67$ for trachytic and $0.13-0.33$ for tephrytic rocks) ratios are, with a few exceptions, between primitive mantle and crustal ratios. These observed ratios suggest crustal assimilation coupled with fractional crystallisation. Supporting this idea, the Eocene and Miocene volcanic rocks include some evidence of disequilibrium crystallisation: (1) sieved and rounded, embayed plagioclases, normally and reversely zoned plagioclases and coexisting of these two types in the same samples from the basaltic and trachytic rocks; (2) zoning, resorbed cores and mantles, rounded crystals, and embayed rims in the clinopyroxene in the basaltic, trachytic and tephrytic rocks (Yücel et al., 2014a). The magma ascent through the crust increases the probability of crustal contamination and/or mixing that could produce some of their isotopic and incompatible trace element signatures.

The $\mathrm{Sr}$ and $\mathrm{Nd}$ isotopic budget of the studied volcanic rocks shows rather complex behaviours with differentiation index such as $\mathrm{SiO}_{2}$ and $\mathrm{MgO}$. The existence of positive or negative correlations on $\mathrm{Sr}-\mathrm{Nd}$ isotopes versus several elements or ratios can be used to evaluate the role of FC and AFC 
processes for the studied Eocene and Miocene volcanic rocks. All positive or negative trends in Fig. 8 reveal that not only the $\mathrm{FC}$ but also the AFC processes are effective in the evolution of the studied Eocene and Miocene volcanic rocks.

To examine crustal assimilation-crystallisation processes, modelling was performed according to equation of De Palolo (1981) using different crustal end-members such as a Palaeozoic- aged granite (T135, Kaygusuz et al., 2012) and a limestone (ERN57, Boari et al., 2009). Because of a lack of samples representing potential parental magma composition for the Eastern Pontides, sample K-9356 from western Anatolia (Kula volcanic rocks; Alıcı et al., 2002) was chosen as a reference for a parental magma composition with an OIB-like asthenospheric character. Different theoretical curves were produced for two different values of $r=0.2$ and $r=0.3$ (the ratio of the rate of assimilation to the rate of FC) to obtain an immediate estimation of the assimilation rate of crustal material by the ascending magmas. The initial ${ }^{87} \mathrm{Sr} /{ }^{86} \mathrm{Sr}$ and ${ }^{143} \mathrm{Nd} /{ }^{144} \mathrm{Nd}$ ratios of the assimilants (T135, ERN57) were re-evaluated for an age of $45 \mathrm{Ma}$ (Middle Eocene). The value of F represents the ratio of the final mass of magma to its initial mass, and has been marked on each curve decreasing from the parental magma to crustal end- members (Fig. 9a, b). The calculated curves indicate hypothetical trajectories, along which a particular parental magma composition will evolve for different values of $D_{\mathrm{Sr}}$ and $D_{\mathrm{Nd}}$ (bulk distribution coefficients, Table 5).

As previously mentioned, the composition of primary magmas may be evolved via crustal contamination and/or other magmatic processes. The basement of the studied and surrounding areas is generally composed of Carboniferous granites (Kaygusuz et al., 2012), Jurassic-Cretaceous neritic and pelagic carbonates, and thick Late Cretaceous carbonate-bearing formations. The results obtained from AFC modelling using Carboniferous granite and limestone as crustal end-members validate the assimilation of carbonates during evolution of the generally Si-undersaturated Miocene tephrytic rocks. Silica saturation of potassic rocks was controlled by $\mathrm{X}_{\mathrm{CO} 2}$ during partial melting of the metasomatised mantle source (Wendlandt and Eggler, 1980a, b). Another possibility to generate the silica-undersaturated magmas is carbonatitic metasomatism in the source region (e.g. Litasov et al., 2013; Ivanov and Litasov, 2014; Safonova et al 2015). Subducted oceanic crust consists of serpentinites, hydrated sediments, carbonates, and carbonatised basalts can supply water and carbon dioxide to the deep mantle, leading to carbonatitic metasomatism in the source (e.g. Safonova et al., 2015). However, the reason for the silica undersaturated character of the partial melts is the main question that this character can be generated under the effect of either carbonate assimilation in the crust or carbonatitic metasomatism in the source. Si-undersaturated contaminated magmas can be a consequence of carbonate rock assimilation (e.g. Peccerillo et al., 2010; Gozzi et al., 2014; Prelević et al., 2015; Lustrino et al., 2016). Experimental studies also show that crystallisation of Ca-rich clinopyroxene resulted in desilication of the melt, and an increase of Si-undersaturation was driven by carbonate syntexis (Prelević et al., 2015, and references therein). The clinopyroxenes from the Miocene tephrytic rocks were classified as salite with high $\mathrm{CaO}$ content by Yücel et al. (2014a). 
Besides, occurence of fluor apatite crystals in the Miocene tephrytic rocks (Yücel et al. 2014a) indicates fluorine-rich volatiles during the fractional crystallization associated with carbonate wallrock assimilation of silicate melt. Furthermore, Aydin et al. (2008) reported the presence of calcium rich cancrinite-vishnevite group minerals (generally cancrinite) in the tephrytic rocks. Therefore, crystallisation of such high $\mathrm{CaO}$ and/or fluorine and $\mathrm{CO}_{2}$ bearing minerals in Si-undersaturated rocks may result from the assimilation of carbonate rocks, in agreement with experimental results. Besides, the precence of thick Jurrasic-Cretaceous carbonate-bearing formations in the studied region, the source mineralogy indicating mostly the spinel stability field and the model proposed for crustal magma transport and pathway by Yücel et al. (2014a), may support the increasing possibility of carbonate rock assimilation in the crustal levels.

\subsection{Nature and characteristics of mantle sources of Eocene and Miocene volcanic rocks}

Experimental studies have revealed that K-rich magmas can be produced by partial melting of mantle peridotite including hydrous, incompatible-rich metasomatic veins (e.g. Foley, 1992; Mitchell, 1995; Kirchenbaur et al., 2012), although there are several hypotheses questioning the formation of these magmas. The metasomatic net veined mantle composition was characterised by a lower melting degree than wall-rock peridotite (e.g. Foley, 1992).

Upper mantle composition and mineralogy can be estimated using REEs due to the different REE partition coefficients of spinel and garnet (Thirwall et al., 1994; Shaw et al., 2003). Garnet tends to fractionate strongly HREEs in its crystal structure. The melts derived from the garnet stability field generally tend to have high $\mathrm{Dy} / \mathrm{Yb}$ ratios ( $>2.5$ ), whereas a spinel- bearing source has lower $\mathrm{Dy} / \mathrm{Yb}$ ratios ( $<1.5$; Yang et al., 2012). Melts with $\mathrm{Dy}_{\mathrm{N}} / \mathrm{Yb}_{\mathrm{N}}$ ratios lower than 1.06 generally refer to a spinelbearing source (Blundy et al., 1998).

To investigate the source composition of the Eocene and Miocene volcanic rocks established using the mafic samples from this study, with $\mathrm{SiO}_{2}$ content lower than wt. 52\%. The Miocene tephrytic rocks generally have intermediate $\mathrm{Dy}_{\mathrm{N}} / \mathrm{Yb}_{\mathrm{N}}$ ratios ranging from 1.44-1.97, whereas the Eocene basaltic rocks have lower $D y_{N} / Y_{N}$ ratios from 1.01-1.53. Thus, intermediate $D y_{N} / Y_{N}$ ratios in the tephrytic rocks imply that the melts were derived from garnet- and spinel-bearing peridotite facies, indicating a deeper source region. The lower $\mathrm{Dy}_{\mathrm{N}} / \mathrm{Yb}_{\mathrm{N}}$ ratios of the basaltic rocks suggest derivation from a spinel lherzolitic mantle composition. The batch melting equation calibrated by Shaw (1970) was used to determine source mineralogy and the degree of partial melting of the studied volcanic rocks. Two different mineral assemblages, a spinel-bearing lherzolite and a garnet-bearing lherzolite, are used to determine source mineralogy and compositions. The partition coefficients for partial melting modelling calculations are listed in Table 6. In an $\mathrm{Yb}$ versus $\mathrm{La} / \mathrm{Yb}$ diagram (Fig. 10a), the basaltic rocks $\left(\mathrm{SiO}_{2}<52\right.$ wt. \%) rocks plot on a line defined by mixing between $10 \%$ melted spinel lherzolite and $3 \%$ melted garnet lherzolite, whereas the tephrytic rocks plot on a line suggesting mixing between 
$1 \%$ melted spinel lherzolite and $0.1 \%$ melted garnet lherzolite. The budget of alkaline and alkaline earth elements as $\mathrm{K}, \mathrm{Rb}, \mathrm{Sr}$ and $\mathrm{Ba}$ is also useful to have an idea about the presence of $\mathrm{K}$-bearing hydrous phases, such as amphibole and phologopite in the mantle source (Furman and Graham, 1999). Fig. $10 \mathrm{~b}(\mathrm{Rb} / \mathrm{Sr}$ versus $\mathrm{Ba} / \mathrm{Rb}$ diagram; Duggen et al., 2005) can be used to test whether phologopite or amphibole was present or not in the source. The basaltic rocks, with low $\mathrm{Ba} / \mathrm{Rb}$ ratios, have the signature of phologopite as the hydrous phase in the source, while the precence of amphibole was inferred for the source of the tephrytic rocks from their high $\mathrm{Ba} / \mathrm{Rb}$ ratios. Therefore, these data suggest that the parental magma of the Eocene basaltic and trachytic rocks was derived from a phologopite-bearing spinel lherzolite source. On the other hand, the melting modelling using trace elements suggests that the parental magmas of the Miocene tephrytic rocks $\left(\mathrm{Dy}_{\mathrm{N}} / \mathrm{Yb}_{\mathrm{N}}=1.44-1.97\right)$ were derived from an amphibole-bearing net veined mantle in the spinel stability field, which was previously metasomatised by melts derived from the garnet stability field.

The origin of the strong depletion in Nb-Ta-Ti and significant enrichment in LILE and LREE contents of the studied volcanic rocks could also be derived from subduction-related metasomatism in the lithospheric mantle (e.g. Foley et al., 1987; Thirlwall et al., 1994; Pearce and Peate, 1995; Turner, 2005; Alther et al., 2008; Boari et al., 2009). HFSE depletion is attributed to the retention of these elements in the subducting slab during progressive dehydration, whereas the LILEs and LREEs were transported upward by slab-derived fluids, melts or recycled terrigeneous sediments to fertilise the overlying mantle wedge (Peccerillo, 1985; Conticelli and Peccerillo, 1992; Hawkesworth et al., 1993; Münker et al., 2004; Zhao et al., 2009). Therefore, significant LILE and LREE enrichment of Eocene and Miocene volcanic rocks seem to be consistent with the derivation from subduction-modified lithospheric mantle (Pearce and Peate, 1995). The systematic decrease of $\mathrm{Nb}-\mathrm{Ta}$ and $\mathrm{Ti}$ anomalies from the Eocene basaltic rocks to the Miocene tephrytic rocks may be caused by different degrees of enrichment in the source during subduction, or by the addition of more primitive melts to a previously metasomatised lithospheric mantle.

The positive $\varepsilon \mathrm{Nd}_{(\mathrm{i})}$ values of both Eocene and Miocene volcanic rocks suggest that a depleted mantle or mantle-derived end-member was involved in the petrogenesis, while the conjunction of relatively high $\left({ }^{87} \mathrm{Sr} /{ }^{86} \mathrm{Sr}\right)_{\mathrm{i}}$ values of the Miocene tephrytic rocks seems to imply an additional enriched crustal component (Faure and Mensing, 2005). Enrichment of a mantle source by subducted sediments can be detected using $\mathrm{Pb}$ isotopic ratios because of the low $\mathrm{Pb}$ content of the mantle $(<0.2$ ppm) and high $\mathrm{Pb}$ abundances in pelagic sediments ( 20 ppm; White and Dupré, 1986; Plank and Langmuir, 1998). The $\mathrm{Pb}$ isotope composition of the Eocene basaltic and trachytic rocks plots within the mantle array and overlaps in the field of pelagic sediments; while the Miocene tephrytic rocks plot around the N-African sediments field and Late Cretaceous Everek Hanları (Bayburt) alkaline volcanic rocks. The differences in $\mathrm{Pb}$ isotope ratios between the Eocene and Miocene volcanic rocks can be readily explained by the flushing of a depleted mantle source with a subduction component temporally 
and spatially enriched by sediments with high $\mathrm{Pb}$ isotope ratios, or from an isotopically more radiogenic asthenospheric mantle.

As previously discussed, subduction-related melt- and/or fluid- like metasomatism appears to be the dominant process in the petrogenesis of the studied rocks; but the characteristics of this efficient component are contentious (e.g. Hawkesworth et al., 1997; Woodhead et al., 2001; Plank, 2005; Kirchenbaur et al., 2012). The origin of the metasomatic component of subduction-related magmas can be effectively identified using incompatible trace element ratios (Hawkesworth et al., 1997). The modification of the source region by a melt- or fluid-like metasomatic component can be discussed using a $\mathrm{Ba} / \mathrm{Th}$ versus Th (ppm) diagram (Fig. 11a). The basic samples of the Eocene basaltic rocks $\left(\mathrm{SiO}_{2}<52\right.$ wt.\%) show relatively low Th contents and high $\mathrm{Ba} / \mathrm{Th}$ ratios, while the Miocene tephritic rocks exhibit relatively high $\mathrm{Th}$ contents and low $\mathrm{Ba} / \mathrm{Th}$ ratios. Although the predominance of subduction related fluid- and melt-like metasomatism in the source may explain such features, the low degree of partial melting of net veined lithospheric mantle source can be efficient for Th enrichment in Miocene tephrytic rocks. On the other hand, the basaltic rock characteristics suggest fluid-like metasomatism in the source region. The $\mathrm{Th} / \mathrm{Yb}$ versus $\mathrm{Ba} / \mathrm{La}$ diagram (Fig. 11b) shows that the tephrytic rocks were enriched in Th compared to the basaltic rocks. The enrichment in Th relative to $\mathrm{Yb}$ may be explained by complete consumption of phlogopite during melting of hydrous mafic mineral-bearing net veined mantle (e.g. Kirchenbaur et al., 2012). Furthermore, the basaltic rocks yield scattered $\mathrm{Sr} / \mathrm{La}$ ratios in contrast to stable $\mathrm{La} / \mathrm{Yb}$ ratios (Fig. 11c), suggesting that the source of the basaltic rocks was modified by fluid-like metasomatism, in contrast to the source of the tephrytic rocks derived from net veined mantle.

Illustrated in Figs. 12a and $12 \mathrm{~b}$ is a three-component mixing model using lower crust (LC), local upper crust (UC; T135, Kaygusuz et al., 2012) and upper mantle (UM) Sr-Nd-Pb isotopic ratios (Table 7). The Eocene basaltic and trachytic rocks plot on the mixing line between the upper mantle and local upper crust, but the Miocene tephrytic rock samples plot outside the mixing line with higher ${ }^{206} \mathrm{~Pb} /{ }^{204} \mathrm{~Pb}$ ratio. The data obtained from a three-component mixing model reveal that the sources of the Eocene and Miocene volcanic rocks were formed by adding a small amount of crustal material around $3 \mathrm{wt} \%$ to the mantle source, leading to the final $\mathrm{Sr}-\mathrm{Nd}-\mathrm{Pb}$ isotopic budget of the studied volcanic rocks. The drift in the mixing model to the outer side of the mixing line between upper mantle and upper crust for the Miocene tephrytic rocks needs the contribution of a more radiogenic (i.e. higher ${ }^{206} \mathrm{~Pb} /{ }^{204} \mathrm{~Pb}$ ratio) crustal component.

\subsection{Tectonomagmatic implications}

The Eastern Pontides were substantially built during the Alpine-Himalayan orogeny, resulting in a complex tectonic environment. Previous tectonic and geochemical studies (e.g., Şengör and Y1lmaz, 1981; Boztuğ et al., 2004; Eyüboğlu et al., 2011; Temizel et al., 2012; Arslan et al., 2013; Temizel et 
al., 2016), which have discussed the geodynamic model, can shed further light on the tectonomagmatic evolution of the Eastern Pontides as a palaeo-magmatic arc developed as a result of the subduction of the Neo-Tethyan oceanic crust beneath the EP (Y1lmaz et al., 1997; Okay and Şahintürk, 1997). Subduction initiated in Jurassic times, and ended in Paleocene times with the collision between the Pontides and the TAP, and caused the closure of the Neo-Tethyan Ocean. The timing and polarity of subduction and collision between the Pontides and the TAP is still a matter of debate. Accounting for the tectono-magmatic evolution of the region, no available final model reached concurrence due to the lack of detailed structural, geophysical (palaeomagnetic and seismic tomographic) studies, as well as the consecutive contribution of subduction versus mantle geodynamics. Despite contrasting interpretations, most workers (Şengör and Y1lmaz, 1981; Y1lmaz et al., 1997; Okay and Şahintürk, 1997; Boztuğ et al., 2004) believe that Tertiary volcanic rocks in the Eastern Pontides were generated as a result of crustal thickening and subsequent regional uplift related to a Paleocene ( 55 Ma) collision. Tokel (1977) and Robinson et al. (1995) suggest that the polarity of subduction was northward, and that the collision occurred during Oligocene time ( $\sim 30 \mathrm{Ma})$. Alternatively, Eyüboğlu et al. (2011) argued that Tertiary volcanic rocks developed by slab window-related processes during ridge subduction in a southward-dipping subduction zone. Besides, the Tertiary volcanism in Western, Eastern Anatolia and Pontides as part of Alp-Himalayan system in the Eastern Mediterranean region was ascribed to post-collisional tectonic settings (Yilmaz et al., 1997; Arslan and Aliyazicioglu, 2001; Keskin et al., 2008; Kürkcüoğlu et al., 2008; Temizel and Arslan, 2009; Topuz et al., 2011; Temizel et al., 2012; Arslan et al., 2013). To explain the relationship between post-collisional extension and magmatism in Turkey, different models have been proposed by many workers; (i) the slab break-off (e.g., Keskin, 2003; Köprübaşı and Aldanmaz, 2004; Altunkaynak and Dilek, 2006; Altunkaynak, 2007; Dilek and Altunkaynak, 2007) and slab tearing (e.g., Prelević et al., 2015); (ii) slab windowrelated processes (e.g., Eyüboğlu et al., 2011); and (iii) lithospheric delamination (e.g., Aldanmaz et al., 2000; Karslı et al., 2010; Temizel et al., 2012; Arslan et al., 2013; Aydınçakır and Şen, 2013; Aslan et al., 2014). In these models, magma generation is generally attributed to asthenospheric upwelling and decompressional melting due to partial convective removal of the subcontinental lithospheric mantle (e.g., Altunkaynak and Genç, 2008; Dilek and Altunkaynak, 2009; Dilek et al., 2009; Dilek and Sandvol, 2009; Dilek et al., 2010; Altunkaynak et al., 2012; Temizel et al., 2012; Arslan et al., 2013).

Although the slab breakoff model was suggested as viable model to explain the narrow Middle Eocene volcanism throughout the Central Pontides (e.g., Keskin et al., 2008), the feasibility of the lithospheric delamination model is suggested to explain the widespread Middle Eocene volcanism in the Eastern Pontides (e.g., Keskin et al., 2008; Temizel et al., 2012; Arslan et al., 2013; Aslan et al., 2014). Besides, the Eastern Pontides are also affected by post-collisional extensional collapse by delamination (Karslı et al., 2010; Temizel et al., 2012; Arslan et al., 2013; Aslan et al., 2014). The extensional collapse and ongoing extension resulted in widespread Middle Eocene and rare Miocene 
volcanism in the Eastern Pontides (Temizel et al., 2012; Arslan et al., 2013; Aslan et al., 2014; Yücel et al., 2014a).

Recent petrochemical and isotopic data obtained from Eocene and Miocene volcanic rocks in the Eastern Pontides suggest that the magmas evolved from an enriched mantle source initially metasomatised by fluids and/or melts coming from subducted oceanic lithosphere in a collisional and post-collisional extensional related tectonic setting (Arslan and Aliyazıcıoglu, 2001; Aydin et al., 2008; Kaygusuz et al., 2011; Temizet at al., 2012; Arslan et al., 2013; Aslan et al., 2014). The change in stress regime from compressional to extentional and/or heterogeneous composition of lithosperic mantle under the Eastern Pontides orogenic belt could be the cause of the evolution from calc-alkaline volcanism in the southern part to mildly alkaline or calc-alkaline-alkaline transitional volcanism in the northern part during Eocene times, and moderately alkaline volcanism during Miocene times. Therefore, the composition of lithospheric mantle of the Eastern Pontides may be interpreted as heterogeneous during Tertiary period based on petrochemical and isotopic data. Even if alkaline magmas have a limited volumetric distribution compare to others, they have key role to understand mantle metasomatism and evolution. While alkaline volcanic rocks such as lamproite and kamafugite rocks are generally found in intraplate settings, silica-undersaturated alkaline rocks such as leucitites observed in convergent plate margins are, generally associated with calc-alkaline magmatism (Conticelli et al., 2002). Melting of a heterogeneous mantle source characterised by the presence of net hydrous phases bearing veined metasomatic domains and surrounding peridotites under a postcollisional tectonic regime results in different melt types. Lamproitic melts are produced by melting of a vein-dominated source, while dilution of the vein melt by increased partial melting of surrounding peridotites produces shoshonitic, high-K and calc-alkaline melts (e.g., Foley, 1992; Prelević et al., 2005, 2008; Conticelli et al., 2007, 2009a, Prelević et al., 2012). Prelević et al. (2008) support the idea that such hydrous mafic phases bearing net veined mantle is probably present in the entire AlpHimalayan orogenic belt. The degree of melting also contributes to determining the affinity of the magmas. Alkaline magmas generally ensue from a higher melting degree of lithospheric mantle at a shallower depth, as a result of progressive lithospheric thinning and associated asthenospheric upwelling (Kolb et al., 2012). The melting processes of the mantle during Tertiary times could be one of the following models: (i) melting triggered by perturbation of the geotherm as a result of heat flow due to asthenospheric upwelling; (ii) decompressional melting of lithospheric mantle because of lithospheric thinning during extension (e.g. Wilson et al., 1997); and (iii) melting of lithospheric mantle resulting from heat flow facilitated by a mantle plume.

In order to generate parental melts in the Eastern Pontides during Middle Eocene times, the feasible mechanism of lithospheric mantle melting is a perturbation of the geotherm subsequent to an asthenospheric upwelling related to delamination (e.g. Karsl1 et al., 2010; Temizel et al., 2012; Arslan et al., 2013) and/or slab break-off (e.g. Keskin et al., 2008; Eyüboğlu et al., 2011) models. The mantle beneath the Eastern Pontides was metasomatised by fluids derived from a subducted slab during paleo- 
subduction from Jurassic to Paleocene time. This metasomatic event resulted in the development of hydrous phases bearing net veined mantle in the spinel stability field, as previously reported for the entire Alp-Himalayan orogenic belt (Prelević et al., 2008). The metasomatic mineral assemblage has a lower melting point than the surrounding peridotites (Foley, 1992).

After collision of TAP and Pontides in Paleocene time, the geodynamic evolution of the region was governed by post-collisional extension, probably caused by strike-slip tectonics. A change in stress regime from compression to extension related to lithospheric delamination controlled by the regional strike-slip movements led to an asthenospheric upwelling that induced an increase in temperature at the base of the lithosphere, resulting in lithospheric mantle and/or lower crustal melting. An increase in the melting degree of this heterogeneous lithospheric mantle source would lead to melting not only the net veined mantle, but also the surrounding peridotites. The hydrous phases bearing alkaline magmas were produced by melting of a metasomatic veined mantle whereas anhydrous mildly alkaline or alkaline-calcalkaline transitional magmas resulted from a higher melting degree of the surrounding peridotites together with net veined mantle. Tensional fracturing of the lithosphere creates a pathway for ascending magmas that pause at different crustal levels. Hydrous and anhydrous magmas derived from net veined and/or surrounding peridotite experienced mixing processes within deep, middle and shallow level crustal magma chambers (Fig. 13a-d). Nevertheless, $\mathrm{Sr}-\mathrm{Nd}-\mathrm{Pb}$ isotopic data suggest limited crustal assimilation by ascending magmas for Middle Eocene volcanic rocks.

There seems to be a magmatic silence from Middle Eocene (45-41Ma) to Late Miocene (6$5 \mathrm{Ma}$ ) time in the study area, since there is lack of geochronological data throughout the Eastern Pontides Tertiary magmatism, except for limited Early Oligocene (30Ma; Aslan et al., 2014) and Middle Miocene (16-17 Ma; Temizel et al., 2012; Aslan et al., 2014) volcanism. Therefore, continuing lithospheric delamination can also be a reliable model for the Miocene volcanism in the Eastern Pontides (Aydın et al., 2008; Temizel et al., 2012; Arslan et al., 2013; Aslan et al. 2014). However, the distinct geochemical characters and limited distribution and volume of Late Miocene volcanism in the region necessitate an extensional mechanism controlled via strike-slip tectonics to trigger the volcanism during delamination. The collisional and post-collisional events in the Eastern Pontides resulted in a complex crustal architecture during Paleocene-Miocene times. The strike-slip movements have played an important role in shaping the morphology of the region, since E-W-, NE-SW- and NW-SE trending lineaments and block faulted architecture are important extensional tectonic structures of the Pontides crust (Bektaş and Çapkınoğlu, 1997; Maden et al., 2009). Besides, Eyüboğlu et al. (2006) suggest that these structural trends, which coincide with gravity and magnetic lineament anomalies, control the neotectonic evolution of the Eastern Pontides magmatic arc. This tectonic system can create pathways for magma transport to the surface, and controls the magma residence time and the petrological processes (such as magma mixing and/or contamination) during ascent of magmas through the crust. In the region, some intrusive rocks cropping out along faults zones, similar 
to left-lateral NE-SW strike-slip faults (Kurt et al., 2006), can be regarded as pop-up or flowerstructures. Likewise, the studied Miocene volcanic rocks are limited by two such left-lateral NE-SW strike-slip faults (Maden et al. 2009; Fig. 14a). Such strike-slip faults can generate tensional fractures and extensional areas (Fig. 14b), able to facilitate rising pathways for Miocene volcanism. The extensional tectonics combined with strike-slip movement at the regional scale following collision and delamination led to decompression in an enriched lithospheric mantle characterised by the presence of a net veined metasomatic mineral assemblage, which resulted from metasomatism by melts derived from the garnet stability field. The low partial melting degree of this metasomatic component of the lithospheric mantle with a lower melting point than the surrounding peridotites allows the formation the incompatible element-enriched moderately alkaline melts in the spinel stability field. Tensional fracturing of the lithosphere beneath the Eastern Pontides orogenic belt assures tectonic control on the ascent of small volumes of magma for the Miocene tephritic rocks. The petrological data combined with petrographic and mineral chemistry data reported by Yücel et al. (2014a) indicate that crustal magma chamber processes such as mixing, in three different magma storage regions, are characterised by a polybaric evolutionary path similar to the Eocene ones. Even if $\mathrm{Sr}-\mathrm{Nd}-\mathrm{Pb}$ isotopic data and petrological modelling do not forcefully support assimilation processes, the silica-undersaturated Miocene tephrytic rocks and a petrographical composition characterised by the presence of Ca-rich clinopyroxenes and flourapatite and/or cancrinite-vishnevite group minerals suggest the assimilation of carbonate rocks in shallow-level crustal magma chambers.

\section{Conclusions}

${ }^{40} \mathrm{Ar}-{ }^{39} \mathrm{Ar}$ geochronology, whole-rock and $\mathrm{Sr}-\mathrm{Nd}-\mathrm{Pb}$ isotopic geochemical data from the Trabzon-Giresun area volcanic rocks in the northern part of the Eastern Pontides (NE Turkey) shed a new light on the origin and evolution of Middle Eocene and Miocene volcanic rocks, enabling us to reach the following conclusions:

(1) ${ }^{40} \mathrm{Ar}^{39} \mathrm{Ar}$ geochronology of the studied volcanic rocks reveals that the basaltic and trachytic rocks were emplaced in Middle Eocene (Lutetian) time, when tephrytic rocks erupted during Late Miocene (Messinian) time.

(2) The Eocene volcanic rocks are characterised by narrow initial ${ }^{87} \mathrm{Sr} /{ }^{86} \mathrm{Sr}$ ratios from 0.70389 0.70448 with an $\varepsilon \mathrm{Nd}_{(\mathrm{i})}$ range between +1.61 and +3.75 for the basaltic rocks and $0.70408-0.70425$ with an $\varepsilon \mathrm{Nd}_{(\mathrm{i})}$ range between +1.84 and +2.81 for the trachytic rocks. On the other hand, the tephrytic rocks yielded more radiogenic initial ${ }^{87} \mathrm{Sr} /{ }^{86} \mathrm{Sr}$ ratios, between $0.70518-0.70536$ with $\varepsilon \mathrm{Nd}_{(\mathrm{i})}$ between +0.61 and +1.08 .

(3) Trace element and isotopic AFC modelling revealed that the parental magmas of both the Eocene and Miocene volcanic rocks were mostly affected by fractional crystallisation, rather than assimilation coupled with fractional crystallisation and mixing. Based on petrographic, mineral 
chemistry and geochemical data, the silica-undersaturated character of the Miocene tephrytic rocks could be attributed to assimilation of carbonate rocks within shallow-level magma chambers, even if this hypothesis is not completely supported by isotopic AFC modelling data.

(4) The parental magmas of the Eocene volcanic rocks are the result of a relatively high melting degree of a net veined mantle and surrounding peridotite source in the spinel stability field, due to an increase in temperature resulting from an asthenospheric upwelling. The parental magmas of the Miocene volcanic rocks are formed by a relatively low melting degree of a net veined mantle domain, previously formed by metasomatic melts derived from a garnet peridotite source, resulting from decompression due to extensional tectonics combined with strike-slip movement at a regional scale, related to ongoing delamination.

\section{Acknowledgement}

This study is a part of the $\mathrm{PhD}$ thesis of the first author. The authors gratefully acknowledge the Turkish Scientific Research Council (TUBITAK-ÇAYDAG; Project no: 108Y204) and the Karadeniz Technical University (BAP Project no: 771). We would also like to thank to Dr. Nafiz Maden (Gümüşhane University, Turkey) for geophysical interpretations. We thank associate editor Inna Safonova and anonymous reviewers for their critical and constructive comments to improve our paper.

\section{References}

Aldanmaz, E., Pearce, J.A., Thirlwall, M.F., Mitchell, J.G., 2000. Petrogenetic evolution of late Cenozoic, post-collision volcanism in western Anatolia, Turkey. Journal of Volcanology and Geothermal Research 102, 67-95.

Alıc1, P., Temel, A., Gourgaud, A., 2002. Pb-Nd-Sr isotope and trace element geochemistry of Quaternary extension-related alkaline volcanism: a case study of Kula region (western Anatolia, Turkey). Journal of Volcanology and Geothermal Research 115, 487-510.

Altherr, R., Topuz, G., Siebel, W., Şen, C., Meyer, H.P., Satır, M., Lahaye, Y., 2008. Geochemical and $\mathrm{Sr}-\mathrm{Nd}-\mathrm{Pb}$ isotopic characteristics of Paleocene plagioleucitites from the eastern Pontides (NE Turkey). Lithos 105, 149-161.

Altunkaynak, Ş., 2007. Collision-driven slab breakoff magmatism in northwestern Anatolia, Turkey. Journal of Geology 115, 63-82.

Altunkaynak, Ş., Dilek, Y., 2006. Timing and nature of postcollisional volcanism in western Anatolia and geodynamic implications. In: Dilek Y, Pavlides S (eds) Postcollisional tectonics and magmatism in the Mediterranean region and Asia. Geological Society of America Special Paper 409, 321-351. 
Altunkaynak, Ş., Genç, Ş.C., 2008. Petrogenesis and time-progressive evolution of the Cenozoic continental volcanism in the Biga Peninsula, NWAnatolia (Turkey). Lithos 102, 316-340.

Altunkaynak, Ş., Dilek, Y., Genç, C.Ş., Sunal, G., Gertisser, R., Furnes, H., Foland, K.A., Yang, J., 2012. Spatial, temporal and geochemical evolution of Oligo-Miocene granitoid magmatism in western Anatolia, Turkey. Gondwana Research 21, 961-986.

Arima, M., Edgar, A.D., 1983. High pressure experimental studies on a katungite and their bearing on the genesis of some potassium rich magmas of the west branch of the African rift. Journal of Petrology 24, 166-187.

Arslan, M., Aliyazıcıŏglu, İ., 2001. Geochemical and petrochemical characteristics of the Kale (Gümüşhane) volcanic rocks: implications for the Eocene evolution of Eastern Pontide arc volcanism, Northeast Turkey. International Geology Review 43(7), 595-610.

Arslan, M., Aslan, Z., 2006. Mineralogy, petrography and whole-rock geochemistry of the Tertiary granitic intrusions in the Eastern Pontides, Turkey. Journal of Asian Earth Sciences 27, 177-193.

Arslan, M., Tüysüz, N., Korkmaz, S., Kurt, H., 1997. Geochemistry and petrogenesis of the eastern Pontide volcanic rocks, Northeast Turkey. Chemie der Erde - Geochemistry 57, 157-187.

Arslan, M., Kadir, S., Abdioğlu, E., Kolayl1, H., 2006. Origin and formation of kaolinite in saprolite of the Tertiary alkaline volcanic rocks, Eastern Pontides, NE Turkey. Clay Minerals 41, 599619.

Arslan, M., Temizel, İ., Abdioğlu, E., Kolaylı, H., Yücel, C., Boztuğ, D., Şen, C., 2013. ${ }^{40} \mathrm{Ar}-{ }^{39} \mathrm{Ar}$ dating, whole-rock and $\mathrm{Sr}-\mathrm{Nd}-\mathrm{Pb}$ isotope geochemistry of post-collisional Eocene volcanic rocks in the southern part of the Eastern Pontides (NE Turkey): Implications for magma evolution in extension-induced origin. Contributions to Mineralogy and Petrology 166, 113142.

Arslan, M., Hoskin, P.W.O., Aslan, Z., 2001. Continental crust formation and thermal consequences of Cenozoic thickening of the Eastern Pontides Tectonic unit: Preliminary temporal constraints and implications. Fourth international Turkish geology symposium, Adana-Turkey, Abstracts, $\mathrm{p}$ 121

Arslan, M., Temizel, İ., Abdioğlu, E., 2002. Subduction input versus source enrichment and role of crustal thickening in the generation of Tertiary magmatism in the Pontide paleo-arc setting, NE Turkey. In: De Vivo B, Bodgar RJ (eds) Workshop-Short Course on Volcanic Systems, Geochemical and Geophysical Monitoring, Melt Inclusions: Methods, Applications and Problems. Napoli Italy, pp 13-16.

Aslan, Z., 2010. U-Pb zircon SHRIMP age, geochemical and petrographical characteristics of tuffs within calc-alkaline Eocene volcanics around Gümüşhane (NE Turkey), Eastern Pontides. Neues Jahrbuch für Mineralogie, Abhandlungen 187(3), 329-346.

Aslan, Z., Arslan, M., Temizel, İ., Kaygusuz, A., 2014. K-Ar age, whole rock and Sr-Nd isotope geochemistry of calc-alkaline volcanics around the Gümüşhane area (NE Turkey): implications 
for postcollisional volcanism during Tertiary time in the eastern Pontides. Mineralogy and Petrology 108, 245-267.

Aydın, F., Karsl1, O., Chen, B., 2008. Petrogenesis of the Neogene alkaline volcanics with implications for post-collisional lithospheric thinning of the Eastern Pontides, NE Turkey. Lithos 104, 249-266.

Aydınçakır, E., 2012. Petrography, Geochemistry and Petrogenesis of the Borçka (Artvin, NE Turkey) Area Tertiary Volcanics. PhD thesis Karadeniz Technical University, Trabzon (241 pp.)

Aydınçakır, E., 2014. The petrogenesis of Early Eocene non-adakitic volcanism in NE Turkey: Constraints on the geodynamic implications, Lithos, 208, 361-377.

Aydınçakır, E., Şen, C., 2013. Petrogenesis of the postcollisional volcanic rocks from the Borçka (Artvin) area: Implications for the evolution of the Eocene magmatism in the Eastern Pontides (NE Turkey): Lithos, 172-173, 98-117.

Aydınçakır, E., 2016. Subduction-related Late Cretaceous high-K volcanism in the Central Pontides orogenic belt: Constraints on geodynamic implications, Geodinamica Acta, 28(4), 379-411

Barling, J., Goldstein, S.L., 1990. Extreme isotopic variations in Heard Island lavas and the nature of mantle reservoirs. Nature 348, 59-62.

Bektaş, O., Yılmaz, C., Taslı, K., Akdăg, K., Özgür, S., 1995. Cretaceous rifting of the eastern Pontide carbonate platform (NE Turkey): the formation of carbonates breccias and turbidites as evidences of a drowned platform. Geologia 57 (1-2), 233-244.

Bektaş, O., Çapkınoğlu, Ş., 1997. Doğu Pontid magmatik arkında (KD, Türkiye) neptünyen dayklar ve blok tektoniği. Geosound 30, 451-463.

Bektaş, O., Şen, C., Atıcı, Y., Köprübaşı, N., 1999. Migration of the Upper Cretaceous subductionrelated volcanism toward the back-arc basin of the eastern Pontide magmatic arc (NE Turkey). Geological Journal 34, 95-106.

Blundy, J., Robinson, J. and Wood, B., 1998. Heavy REE are compatible in clinopyroxene on the spinel lherzolite solidus. Earth and Planetary Science Letters 160, 493-504.

Boari, E., Tommasini, S., Laurenzi, M.A., Conticelli, S., 2009. Transition from ultrapotassic kamafugitic to sub-alkaline magmas: $\mathrm{Sr}, \mathrm{Nd}$, and $\mathrm{Pb}$ isotope, trace element and ${ }^{40} \mathrm{Ar}-{ }^{39} \mathrm{Ar}$ age data from the Middle Latin Valley volcanic field, Roman Magmatic Province, Central Italy. Journal of Petrology 50, 1327-1357.

Bozkurt, E., Mittwede, S.K., 2001. Introduction to the geology of Turkey-a synthesis. International Geology Review 43, 578-594.

Boztuğ, D., Jonckheere, R.C., Wagner, G.A., Yeğingil, Z., 2004. Slow Senonian and fast Paleoceneearly Eocene uplift of the granitoids in the Central Eastern Pontides, Turkey: apatite fission track results. Tectonophysics 382(3-4), 213-228.

Bradshaw, T.K., Hawkesworth, C.J., Gallagher, K., 1993. Basaltic volcanism in the southern Basin and Range: no role for a mantle plume. Earth and Planetary Science Letters 116, 45-62. 
Chase, C.G., 1981. Oceanic island Pb:Two-stage histories and mantle evolution. Earth and Planetary Science Letters 52, 277-284.

Chauvel, C., Hofmann, A.W., Vidal, P., 1992. HIMU-EM: The French Polynesian connection. Earth and Planetary Science Letters 110, 99-119.

Chorowicz, J., Dhont, D., Adıyaman, Ö., 1998. Black Sea-Pontid relationship: interpretation in terms of subduction. Third International Turkish Geology Symposium: Ankara, Turkey, p. 258 (Abstracts).

Conticelli, S., Peccerillo, A., 1992. Petrology and geochemistry of potassic and ultrapotassic volcanism in central Italy: petrogenesis and inferences on the evolution of the mantle sources. Lithos 28, 221-240.

Conticelli, S., D’Antonio, M., Pinarelli, L., Civetta, L., 2002. Source contamination and mantle heterogeneity in the genesis of Italian potassic and ultrapotassic volcanic rocks: $\mathrm{Sr}-\mathrm{Nd}-\mathrm{Pb}$ isotope data from Roman Province and Southern Tuscany. Mineralogy and Petrology 74, 189222.

Conticelli, S., Carlson, R.W., Widom, E., Serri, G., 2007. Chemical and isotopic composition (Os, Pb, $\mathrm{Nd}$, and $\mathrm{Sr}$ ) of Neogene to Quaternary calc-alkalic, shoshonitic and ultrapotassic mafic rocks from the Italian Peninsula: inferences on the nature of their mantle sources. In: Beccaluva, 1., Biachini, G. \& Wilson, M. (eds) Cenozoic Volcanism in the Mediterranean Area. Geological Society of America, Special Papers 418, 171-202.

Conticelli, S., Marchionni, S., Rosa, D., Giordano, G., Boari, E., Avanzinelli, R., 2009a. Shoshonite and sub-alkaline magmas from an ultrapotassic volcano: $\mathrm{Sr}-\mathrm{Nd}-\mathrm{Pb}$ isotope data on the Roccamonfina volcanic rocks, Roman Magmatic Province, Southern Italy. Contributions to Mineralogy and Petrology 157, 41-63.

Conticelli, S., Guarnieri, L., Farinelli, A., Mattei, M., Avanzinelli, R., Bianchini, G., Boari, E., Tommasini, S., Tiepolo, M., Prelevic, D., Venturelli, G., 2009b. Trace elements and Sr-Nd-Pb isotopes of K-rich, shoshonitic, and calc-alkaline magmatism of the Western Mediterranean Region: Genesis of ultrapotassic to calc-alkaline magmatic associations in a post-collisional geodynamic setting. Lithos 107, 68-92.

Conticelli, S., Avanzinelli, R., Ammannati, E., Casalini M., 2015. The role of carbon from recycled sediments in the origin of ultrapotassic igneous rocks in the Central Mediterranean, Lithos, 232, 174-196.

Çoğulu, E., 1975. Petrologic and Geochronologic Studies in the Gümüşhane-Rize region, İstanbul Technical University Publication 112p.

Davies, J.H., von Blanckenburg, F., 1995 Slab breakoff: a model of lithospheric detachment and its test in the magmatism and deformation of collisional orogens. Earth and Planetary Science Letters $129,85-102$. 
DePaolo, D.J., 1981. Trace element and isotopic effects of combined wallrock assimilation and fractional crystallization. Earth and Planetary Science Letters 53, 189-202.

Dilek, Y., Altunkaynak, Ş., 2007. Cenozoic crustal evolution and mantle dynamics of post-collisional magmatism in western Anatolia. International Geology Review 49(5), 431-453.

Dilek, Y., Altunkaynak, Ş., 2009. Geochemical and temporal evolution of Cenozoic magmatism in western Turkey: Mantle response to collision, slab break-off, and lithospheric tearing in an orogenic belt. In: Van Hinsbergen DJJ, Edwards MA, Govers R (eds) Geodynamics of collision and collapse at the Africa-Arabia- Eurasia Subduction Zone: Geological Society of London, Special Publications 311, 213-233.

Dilek, Y., Sandvol, E., 2009. Seismic structure, crustal architecture and tectonic evolution of the Anatolian-African Plate Boundary and the Cenozoic Orogenic Belts in the Eastern Mediterranean Region. In: Murphy JB, Keppie JD, Hynes AJ (eds) Ancient Orogens and Modern Analogues. Geological Society of London, Special Publications 327, 127-160.

Dilek, Y., Altunkaynak, S., Öner, Z., 2009. Syn-extensional Miocene granitoids in the Menderes core complex (Western Anatolia), and their role in the late Cenozoic extensional tectonics of the Aegean province. In: Ring U, Wernicke BB (eds) Continental Extensional Tectonics. Geological Society of London, Special Publications 321, 197-223.

Dilek, Y., Imamverdiyev, N., Altunkaynak, Ş., 2010. Geochemistry and tectonics of Cenozoic volcanism in the Lesser Caucasus (Azerbaijan) and the peri-Arabian region: collision induced mantle dynamics and itsmagmatic fingerprint. International Geology Review 52 (4-6), 536-578.

Duggen, S., Hoernle, K., Van Den Bogaard, P., Garbe-Schönberg, D., 2005. Post-collisional transition from subduction- to intraplatetype magmatism in the Westernmost Mediterranean: evidence for continental-edge delamination of subcontinental lithosphere. J Petrology 46(6),1155-1201.

Edgar, A.D., 1987. The genesis of alkaline magmas with emphasis on their source regions: inferences from experimental studies. In Fitton JG, Upton BGJ, eds. Alkaline Igneous Rocks. Geological Society of London, Special Publications 30, 29-52.

Edgar, A.D., Condliffe, E., Barnett, R.L., Shirran, R.J., 1980. An experimental study of an olivine ugandite magma and mechanisms for the formations of its K-enriched derivatives. Journal of Petrology 21, 475-497.

Edgar, A.D., Mitchell, R.H., 1997. Ultra high pressure-temperature melting experiments on an SiO2rich lamproite from Smoky Butte, Montana-Derivation of siliceous lamproite magmas from enriched sources deep in the continental mantle: Journal of Petrology 38, 457-477.

Eyüboğlu, Y., 2010. Late Cretaceous high-K volcanism in the eastern Pontides orogenic belt, and its implications for the geodynamic evolution of NE Turkey. International Geology Review 52 (23), 142-186. 
Eyüboğlu, Y., Bektaş, O., Seren, A., Maden, N., Jacoby, W.R., Özer, R., 2006. Three axial extensional deformation and formation of the Liassic rift basins in the Eastern Pontides (NE Turkey). Geologica Carpathica 57 (5), 337-346.

Eyüboğlu, Y., Chung, S.L., Santosh, M., Dudas, F.O., Akaryal1, E., 2011. Transition from shoshonitic to adakitic magmatism in the eastern Pontides, NE Turkey: implications for slab window melting. Gondwana Research 19, 413-429.

Eyüboğlu, Y., Dudas, F.O., Santosh, M., Yi, K., Kwon, S., Akaryali, E., 2013. Petrogenesis and U-Pb zircon chronology of adakitic porphyries within the Kop ultramafic massif (Eastern Pontides Orogenic Belt, NE Turkey). Gondwana Research 24, 742-766.

Faure, G., Mensing, T.M., 2005. Isotopes: Principles and Applications, 3 rd ed. John Wiley and Sons, USA. 897p.

Foley, S.F., Venturelli, G., Green, D.H., Toscani, L., 1987. The ultrapotassic rocks: characteristics, classification and constraints for petrogenetic models. Earth Science Reviews 24, 81-134.

Foley, S., 1992. Vein-plus-wall-rock melting mechanisms in the lithosphere and the origin of potassic alkaline magmas. Lithos 28, 435-453.

Frey, F.A., Green, D.H., Roy, S.D., 1978. Integrated models of basalt petrogenesis: A study of quartz tholeiites to olivine melilitites from South Eastern Australia utilizing geochemical and experimental petrological data. Journal of Petrology 19, 463-513.

Furman, T., Graham, D., 1999. Erosion of lithospheric mantle beneath the east African rift system; geochemical evidence from the Kivu volcanic province. Lithos 48, 237-262.

Gasperini, D., Blichert-Toft, J., Bosch, D., Del Moro, A., Macera, P., Albarede, F., 2002 Upwelling of deep mantle material through a plate window: Evidence from the geochemistry of Italian basaltic volcanics. Journal of Geophysical Research 107, B12, 2367.

Gill, J.B., 1981. Orogenic Andesites and Plate Tectonics, Springer, Berlin, 390p.

Gozzi, F., Gaeta, M., Freda, C., Mollo, S., Di Rocco, T., Marra, F., Dallai, L., Pack, A., (2014) Primary magmatic calcite reveals origin from crustal carbonate. Lithos 190-191, 191-203.

Gill, R., 2010. Igneous Rocks and Processes, a pratical guide. Wiley-Blackwel, UK 428.

Green, T.H., Pearson, N.J., 1985. Rare Earth element partitioning between clinopyroxene and silicate liquid at moderate to high pressure, Contributions to Mineralogy and Petrology 91, 24-36.

Güven, İ.H., 1993. Doğu Pontidler'in 1:25000 ölçekli jeolojisi ve kompilasyonu [1:25000 Scale Geology and Compilation of the Eastern Pontide]. General Directorate of Mineral Research and Exploration of Turkey (MTA), Ankara (unpublished)

Halliday, A.N., Davies, G.R., Lee, D.C., Tommasini, S., Paslick, C.R., Fitton, J.G., James, D.E., 1992. Lead isotope evidence for young trace element enrichment in the oceanic upper mantle. Nature $359,623-627$. 
Halliday, A.N., Lee, D.C., Tommasini, S., Davies, G.R., Paslick, C.R., Fitton, J.G., James, D.E., 1995. Incompatible trace elements in OIB and MORB and source enrichment in the sub-oceanic mantle. Earth and Planetary Science Letters 133, 379-395.

Hanes, J.A., York, D., Hall, C.M., 1985. An ${ }^{40} \mathrm{Ar} /{ }^{39} \mathrm{Ar}$ geochronological and electron microprobe investigation of an Archean pyroxenite and its bearing on ancient atmospheric compositions. Canadian Journal of Earth Science 22, 947-958.

Hart, S.R., 1984. A large-scale isotope anomaly in the southern hemisphere mantle. Nature 309, 753757.

Hart, S.R., 1988. Heterogeneous mantle domains: signatures, genesis and mixing chronologies. Earth and Planetary Science Letters 90, 273-296.

Hastie, A.R., Kerr, A.C., Pearce, J.A., Mitchell, S.F., 2007. Classification of altered volcanic island arc rocks using immobile trace elements: development of the Th-Co discrimination diagram. Journal of Petrology 48 (12), 2341-2357.

Hawkesworth, C.J., Vollmer, R., 1979. Crustal contamination versus enriched mantle: ${ }^{143} \mathrm{Nd} /{ }^{144} \mathrm{Nd}$ and ${ }^{87} \mathrm{Sr} /{ }^{86} \mathrm{Sr}$ evidence from Italian volcanics. Contributions to Mineralogy and Petrology 69, 151165.

Hawkesworth, C.J., Kempton, P.D., Rogers, N.W., Ellam, R.M., van Calsteren, P.W., 1990. Continental mantle lithosphere, and shallow level enrichment processes in the Earth's mantle. Earth and Planetary Science Letters 96, 256-268.

Hawkesworth, C.J., Gallagher, K., Hergt, J.M., Mcdermott, F., 1993. Mantle and slab contributions in arc magmas. Annual Review of Earth and Planetary Sciences 21, 175-204.

Hawkesworth, C.J., Turner, S.P., Peate, D.W., McDermott, F., van Calsteren, P., 1997. U-Th isotopes in arc magmas: implications for element transfer from the subducted crust. Science 276, 551 555.

Hofmann, A.W., White, W.M., 1982. Mantle plumes from ancient oceanic crust. Earth and Planetary Science Letters 57, 421-436.

Hofmann, A. W., 2003. Sampling mantle heterogeneity through oceanic basalts: isotopes and trace elements. In: Carlson, R. W. (ed.) Treatise on Geochemistry 2, 61-101.

Ivanov, A.V., Litasov, K.D., 2014. The deep water cycle and flood basalt volcanism. International Geology Revie,. 56, 1-14.

Karsl1, O., Dokuz, A., Uysal, İ., Aydın, F., Kandemir, R., Wijbrans, R.J., 2010. Generation of the early Cenozoic adakitic volcanism by partial melting of mafic lower crust, Eastern Turkey: implications for crustal thickening to delamination. Lithos 114, 109-120.

Karsl1, O., Dokuz, A., Uysal, İ., Ketenci, M., Chen, B., Kandemir, R., 2012. Deciphering the shoshonitic monzonites with I-type characteristic, the Sisdağ1 pluton, NE Turkey: magmatic response to continental lithospheric thinning. Journal of Asian Earth Sciences 51, 45-62. 
Kaygusuz, A., Siebel, W., İlbeyli, N., Arslan, M., Satır, M., Şen, C., 2010. Insight into magma genesis at convergent plate margins - a case study from the eastern Pontides (NE Turkey). Neues Jahrbuch für Mineralogie, Abhandlungen 187(3), 265-287.

Kaygusuz, A., Aslan, Z., Siebel, W., Şen, C., 2011. Geochemical and Sr-Nd isotopic characteristics of post-collisional calc-alkaline volcanics in the Eastern Pontides (NE Turkey). Turkish Journal of Earth Sciences 20, 137-159.

Kaygusuz, A., Arslan, M., Siebel, W., Sipahi, F., İlbeyli, N., 2012. Geochronological evidence and tectonic significance of Carboniferous magmatism in the southwest Trabzon area, eastern Pontides, Turkey. International Geology Review 54(15), 1776-1800.

Kaygusuz, A., Öztürk, M., 2015. Geochronology, geochemistry, and petrogenesis of the Eocene Bayburt intrusions, Eastern Pontide, NE Turkey: implications for lithospheric mantle and lower crustal sources in the high-K calc-alkaline magmatism. Journal of Asian Earth Sciences 108, $97-116$.

Kaygusuz, A., Arslan, M., Sipahi, F., Temizel, İ., 2016. U-Pb zircon chronology and petrogenesis of Carboniferous plutons in the northern part of the Eastern Pontides, NE Turkey: constraints for Paleozoic magmatism and geodynamic evolution. Gondwana Research, doi:10.1016/j.gr.2016.01.011.

Keskin, M., 2002. FC-Modeler: a Microsoft ${ }^{\circledR}$ Excel@ spreadsheet program for modeling Rayleigh fractionation vectors in closed magmatic systems, Computer Geoscience, 28 (8), 919-928.

Keskin, M., 2003. Magma generation by slab steepening and break off beneath a subductionaccretion complex: an alternative model for collision-related volcanism in Eastern Anatolia, Turkey. Geophysical Research Letters 30 (24), 8046.

Keskin, M., Genç, S.C., Tüysüz, O., 2008. Petrology and geochemistry of post-collisional Middle Eocene volcanic units in North-Central Turkey: evidence for magma generation by slab breakoff following the closure of the Northern Neotethys Ocean. Lithos 104, 267-305.

Keskin, S., Pedoja, K., Bektaş, O., 2011. Coastal Uplift along the Eastern Black Sea Coast: New Marine Terrace Data from Eastern Pontides, Trabzon (Turkey) and a Review. Journal of Coastal Research 27 (6), 63 - 73.

Kirchenbaur, M., Münker, C., Schuth, S., Garbe-Schoönberg, D., Marchev, P., 2012. Tectonomagmatic Constraints on the Sources of Eastern Mediterranean K-rich Lavas. Journal of Petrology 53, 27-65.

Kolb, M., Paulick, H., Kirchenbaur, M., Münker, C., 2012. Petrogenesis of mafic to felsic lavas from the Oligocene Siebengebirge volcanic field (Germany): implications for the origin of intracontinental volcanism in Central Europe. Journal of Petrology 53, 2349-2379.

Korkmaz, S., Tüysüz, N., Er, M., Musaoğlu, A., Keskin, İ., 1995. Stratigraphy of Eastern Pontides, NE Turkey. In: Erler A et al (eds) Geology of black Sea Region. Proce. of the Inter. Symp. On the Geology of Black Sea Region, MTA, Ankara, pp 59-6. 
Köprübaş1, N., Aldanmaz, E., 2004. Geochemical constraints on the petrogenesis of Cenozoic I-type granitoids in Northwest Anatolia, Turkey: evidence for magma generation by lithospheric delamination in a post-collisional setting. International Geology Review 46, 705-729.

Kurt, İ., Özkan, M., Karslı, Ş., Çolak, T. ve Topçu, T., 2006. Doğu Karadeniz Bölgesinin jeodinamik ve Metalojenik Evrimi (Keşap (Giresun)-Çarşıbaşı (Trabzon)-Torul (Gümüşhane) Arasının Jeolojisi), General Directorate of Mineral Research and Exploration of Turkey (MTA), Ankara (unpublished).

Kürkcüoğlu, B., Furmana, T., Hananc, B., 2008. Geochemistry of post-collisional mafic lavas from the North Anatolian Fault zone, Northwestern Turkey. Lithos 101 (3-4), 416-434.

Litasov, K.D., Shatskiy, A., Ohtani, E., Yaxley, G.M., 2013. Solidus of alkaline carbonatite in the deep mantle. Geology 41, 79-82.

Le Bas, M.J., Le Maitre, R.W., Streckeisen, A., Zanettin, B., 1986. A chemical classification of volcanic rocks on the total alkali - silica diagram. Journal of Petrology 27(3), 745-750.

Lee, J.Y., K. Marti, J. P. Severinghaus, K. Kawamura, H.S. Yoo, J. Lee, J. B. Bok., and J. S. Kim, 2006. A redetermination of the isotopic abundances of atmospheric Ar, Geochimica et Cosmochimica Acta 70(17), 4507-4512, doi:10.1016/j.gca.2006.06.1563.

Lloyd, F.E., Arima, M., Edgar, A.D., 1985. Partial melting of a phlogopite-clinopyroxenite nodule from south-west Uganda: an experimental study bearing on the origin of a highly potassic continental rift volcanics. Contributions to Mineralogy and Petrology 91, 321-329.

Lustrino, M., Prelević, D., Agostini, S., Gaeta, M., Di Rocco, T., Stagno, V., Capizzi L.S., 2016. Carich carbonates associated with ultrabasic-ultramafic melts: Carbonatite or limestone xenoliths? A case study from the late Miocene Morron de Villamayor volcano (Calatrava Volcanic Field, central Spain), Geochimica et Cosmochimica Acta doi: 10.1016/j.gca.2016.02.026.

Maden, N., Gelişli, K., Eyüboğlu, Y., Bektaş, O., 2009. Two-and-three-dimensional crustal thickness of the eastern Pontides (NE Turkey). Turkish Journal of Earth Sciences 18 (2), 225-238.

McCulloch, M.T., Kyser, T.K., Woodhead, J.D., Kinsley, L., 1994. Pb-Sr-Nd-O isotopic constraints on the origin of rhyolites from the Taupo Volcanic zone of New Zealand: evidence for assimilation followed by fractionation of basalt. Contributions to Mineralogy and Petrology 115, $303-312$

McDonough, W.F., Sun, S.S., 1995. Composition of the Earth. Chemical Geology 120, 223-253.

McKenzie, D., O’Nions, R.K., 1983. Mantle reservoirs and ocean island basalts. Nature 301, 229-331.

McKenzie, D.P., O’Nions, R.K., 1991. Partial melt distributions from inversion of rare earth element concentrations. Journal of Petrol 32, 1021-1091.

McKenzie, D., Bickle, M.J., 1988. The volume and composition of melt generated by extension of lithosphere. Journal of Petrology 29, 625-679.

McKenzie, D., 1989. Some remarks on the movement of small melt fractions in the mantle. Earth and Planetary Science Letters 95, 53-72. 
Mitchell, R.H., 1995. Melting experiments on a sanidine phlogopite lamproites at 4-7 GPa and their bearing on the sources of lamproitic magmas. Journal of Petrology 36, 1455-1474.

Münker, C., Wörner, G., Yogodzisnki, G., Churikova, T., 2004. Behaviour of high field strength elements in subduction zones: constraints from Kamchatka-Aleutian arc lavas. Earth and Planetary Science Letters 224(3-4), 275-293.

Nakamura, Y., Tatsumoto, M., 1988. Pb, Nd, and Sr isotopic evidence for a multicomponent source for rocks of Cook-Austral Islands and heterogeneities of mantle plumes. Geochimica et Cosmochimica Acta 52, 2909-2924.

Niu, Y., O'Hara, M.J, 2003. Origin of ocean island basalts: A new perspective from petrology, geochemistry, and mineral physics considerations. Journal of Geophysical Research 108, 2209.

Okay, A.İ., Şahintürk, O., 1997. Geology of the eastern Pontides. In: Robinson, AG (ed) Regional and petroleum geology of the Black Sea and surrounding region. Memoir of American Association Petroleum Geologists 68, 291-311.

Okay, A.I., Tüysüz, O., 1999. Tethyan sutures of northern Turkey. Geological Society (London) Special Publications 156, 475-515.

Özsayar, T., Pelin, S., Gedikoğlu, A., 1981. Doğu Pontidler'de Kretase. KTÜ Yer Bilimleri Dergisi 1, 65-114.

Palacz, Z.A., Saunders, A.D., 1986. Coupled trace element and isotope enrichment in the CookAustral-Samoa islands, southwest Pacific. Earth and Planetary Science Letters 79, 270-280.

Panter, K.S., Blusztajn, J., Hart, S.R., Kyle, P.R., Esser, R., McIntosh ,W.C., 2006. The origin of HIMU in the SW Pacific: Evidence from intraplate volcanism in southern New Zealand and subantarctic islands. Journal of Petrology 47, 1673-1704.

Pearce, J.A., Peate, D.W., 1995. Tectonic implications of the composition of volcanic arc magmas. Annual Reviews of Earth and Planetary Science 23, 251-285.

Peate, D. W., Pearce, J. A., Hawkesworth, C. J., Colley, H., Edwards, C. M. H., Hirose, K. 1997. Geochemical variations inVanuatu arc lavas: the role of subducted material and a variable mantle wedge composition. Journal of Petrology 38, 1331-1358.

Peccerillo, A., 1985. Roman Comagmatic Province (Central Italy): Evidence for subduction related magma genesis. Geology 13, 103-106.

Peccerillo, A., 2002. Plio-Quaternary magmatism in central-southern Italy: a new classification scheme for volcanic provinces and its geodynamic implications. Bolletino della Società Geologica Italiana 1, 113-115.

Peccerillo, A., 2003. Plio-Quaternary magmatism in Italy, Episodes 26, 222-226.

Peccerillo, A., Federico, M., Barbieri, M., Brilli, M., Wu, T.-W., (2010). Interaction between ultrapotassic magmas and carbonate rocks: evidence from geochemical and isotopic ( $\mathrm{Sr}, \mathrm{Nd}, \mathrm{O}$ ) compositions of granular lithic clasts from the Alban Hills Volcano, Central Italy. Geochimica et Cosmochimica Acta 74, 2999-3022. 
Pe-Piper, G., 1994. Lead isotopic compositions of Neogene volcanic rocks from the Aegean extensional area. Chemical Geology 118, 27-41.

Pilet, S., Hernandez, J., Sylvester, P., Poujol, M., 2005. The metasomatic alternative for ocean island basalt chemical heterogeneity. Earth and Planetary Science Letters 236, 148-166.

Pilet, S., Baker, M.B., Stolper, E.M., 2008. Metasomatized lithosphere and the origin of alkaline lavas. Science 320, 916-919.

Plank, T., 2005. Constraints from Thorium/Lanthanum on sediment recycling at subduction zones and the evolution of the continents. Journal of Petrology 46, 921-944.

Plank, T., Langmuir, C.H., 1998. The geochemical composition of subducting sediment and its consequences for the crust and mantle. Chemical Geology 145, 325-394.

Prelević, D., Foley, S.F., Romer, R.L., Cvetković, V., Downes, H., 2005. Tertiary ultrapotassic volcanism in Serbia: constraints on petrogenesis and mantle source characteristics. Journal of Petrology 46, 1443-1487.

Prelević, D., Foley, S.F., Romer, R.L., Conticelli, S., 2008. Mediterranean Tertiary lamproites derived from multiple source components in postcollisional geodynamics. Geochimica et Cosmochimica Acta $72,2125-2156$.

Prelević, D., Akal, C., Foley, S.F., Romer, R.L., Stracke, A., Van Den Bogaard, P., 2012. Ultrapotassic mafic rocks as geochemical proxies for post-collisional dynamics of orogenic lithospheric mantle: the case of southwestern Anatolia, Turkey. Journal of Petrology 53, 10191055 .

Prelević, D., Akal, C., Romer, R.L., Mertz-Kraus, R., Helvac1, C., 2015. Magmatic response to slab tearing: constraints from the Afyon Alkaline Volcanic Complex, Western Turkey. Journal of Petrology 56, 527-562.

Renne, P.R., Swisher, C.C., Deino, A.L., Karner, D.B., Owens, T.L., DePaolo, D.L., 1998. Intercalibration of standards, absolute ages and uncertainties in ${ }^{40} \mathrm{Ar} /{ }^{39} \mathrm{Ar}$ dating. Chemical Geology 145, 117-152.

Renne, P.R., Mundil, R., Balco, G., Min, K., Ludwig, K.R. 2010. Joint determination of 40K decay constants and ${ }^{40} \mathrm{Ar} * /{ }^{40} \mathrm{~K}$ for the Fish Canyon sanidine standard, and improved accuracy for ${ }^{40} \mathrm{Ar} /{ }^{39} \mathrm{Ar}$ geochronology. Geochimica et Cosmochimica Acta 74, 5349-5367.

Renne, P.R., Balco, G., Ludwig, K.R., Mundil, R., Min, K., 2011. Response to the comment by W.H. Schwarz et al. on "Joint determination of ${ }^{40} \mathrm{~K}$ decay constants and ${ }^{40} \mathrm{Ar} * /{ }^{40} \mathrm{~K}$ for the Fish Canyon sanidine standard, and improved accuracy for ${ }^{40} \mathrm{Ar} /{ }^{39} \mathrm{Ar}$ geochronology" by P.R. Renne et al., 2010. Geochimica et Cosmochimica Acta 75, 5097-5100.

Rice, S.P., Roberson, A.H.F., Ustaömer, T., İnan, T., Tasl1, K., 2009. Late Cretaceous-Early Eocene tectonic development of the Tethyan Suture Zone in the Erzincan area, eastern Pontides, Turkey. Geological Magazine 146 (4), 567-590. 
Robinson, A.G., Banks, C.J., Rutherford, M.M., Hirst, J.P.P., 1995. Stratigraphic and structural development of the eastern Pontides, Turkey. Journal of Geological Society (London) 152, 861872.

Roddick, J.C., Cliff, R.A., ,Rex D.C., 1980. The evolution of excess argon in alpine biotites - A ${ }^{40} \mathrm{Ar}-$ ${ }^{39}$ Ar analysis. Earth Planetary Science Letters 48, 185-208.

Rollinson, H., 1993. Using Geochemical Data: Evaluation, Presentation, Interpretation. Longman Scientific and Technical, Singapore.

Romick, J.D., 1987. Amphibole fractionation and magma mixing in andesites and dacites from the central Aleutians, Alaska, Transactions American Geophysical Union (EOS), 68, 461.

Rosenthal, A., Foley, S.F., Pearson, D.G., Nowell, G.M., Tappe, S., 2009. Petrogenesis of strongly alkaline primitive volcanic rocks at the propagating tip of the western branch of the East African Rift. Earth and Planetary Science Letters 284, 236-248.

Rosenbaum, J. M., Wilson, M., Downes, H. 1997. Multiple enrichment of the Carpathian^Pannonian mantle: $\mathrm{Pb}-\mathrm{Sr}-\mathrm{Nd}$ isotope and trace element constraints. Journal of Geophysical Research 102, 14947-14961.

Ruffet, G., Féraud, G., Amouric, M., 1991. Comparison of 40Ar/39Ar conventional and laser dating of biotites from the North Tre'gor Batholith. Geochimica et Cosmochimica Acta 55, 1675 - 1688

Ruffet. G., Fe'raud, G., Balle`vre, M., Kie'nast, J.R., 1995. Plateau ages and excess argon in phengites: an ${ }^{40} \mathrm{Ar}-{ }^{39} \mathrm{Ar}$ laser probe study of Alpine micas (Sesia Zone, Western Alps, northern Italy). Chemical Geology (Isotopic Geoscience Section) 121, 327-343.

Ruffet, G., Gruau, G., Ballévre, M., Féraud, G., Philippot, P., 1997. Rb-Sr and ${ }^{40} \mathrm{Ar}-{ }^{39} \mathrm{Ar}$ laser probe dating of high-pressure phengites from the Sesia zone (western Alps): underscoring of excess argon and new age constraints on the high-pressure metamorphism. Chemical Geology 141, 118.

Safonova, I., Maruyama, S., Litasov, K., 2015. Generation of hydrous-carbonated plumes in the mantle transition zone linked to tectonic erosion and subduction, Tectonophysics 662, 454-471.

Shaw, D.M., 1970. Trace element Fractionation during Anatexis. Geochimica et Cosmochimica Acta 34, 237-259.

Shaw, C.S.J, 1996. The petrology and petrogenesis of Roman Province-Type Lavas and ultrapotassic leucitites. In: Mitchell RH (ed) Undersaturated alkaline rocks: mineralogy, petrogenesis, and economic potential. Mineral Ass Canada, Winnipeg, Manitoba, pp 175-192.

Shaw, J.E., Baker, J.A., Menzies, M.A., Thirlwall, M.F., Ibrahim, K.M., 2003. Petrogenesis of the largest intraplate volcanic field on the Arabian plate (Jordan): a mixing lithosphereasthenosphere source activated by lithospheric extension. Journal of Petrology 44, 1657-1679.

Stolz, A.J., Varne, R., Davies, G.R.,Wheller, G.E., Foden, J.D., 1990. Magma source components in an arc-continent collision zone: the Flores-Lembata sector, Sunda arc, Indonesia. Contributions to Mineralogy and Petrology 105, 585-560. 
Stoppa, F., Schiazza, M., 2013. An overview of monogenetic carbonatitic magmatism from Uganda, Italy, China and Spain: volcanologic and geochemical features. Journal of South American Earth Sciences 41, 140-159.

Sun, S.S., McDonough, W.F., 1989. Chemical and isotopic systematics of oceanic basalts: implications for mantle composition and processes. In: Saunders AD, Norry M. (eds) Magmatism in the Ocean Basins. Geological Society, London, Special Publications 42, 313-345.

Şen, C., 2007. Jurassic volcanism in the Eastern Pontides: is it rift related or subduction related? Turkish Journal of Earth Sciences 16(4), 523-539.

Şen, C., Arslan, M., Van, A., 1998. Geochemical and petrological characteristics of the Pontide Eocene (?) alkaline province, NE Turkey. Turkish Journal of Earth Sciences 7, 231-239.

Şengör, A.M.C., Yılmaz, Y., 1981. Tethyan evolution of Turkey: a plate tectonic approach. Tectonophysics $75,181-241$.

Sun, S.S., McDonough, W.F., 1989. Chemical and isotopic systematics of oceanic basalts: implications for mantle composition and processes. In: Saunders AD, Norry MJ (eds) Magmatism in the Ocean Basins. Geol Soc Lond Spec Publ 42, 313-345.

Tanaka, T., Togashi, S., Kamioka, H., Amakawa, H., Kagami, H., Hamamoto, T., Yuhara, M., Orihashi, T., Yoneda, S., Shimizu, H., Kunimaru, T., Takahashi, K., Yanagi, T., Nakano, T., Fujimaki, H., Shinjo, R., Asahara, Y., Tanimizu, M., Dragusanu, C., 2000. JNdi-1: a neodymium isotopic reference in consistency with LaJolla neodymium. Chemical Geology 168, 279-281.

Taylor, S.R., Mclennan, S.M., 1985. The continental crust: its composition and evolution. Blackwell Scientific Publication, Oxford.

Temizel, İ., Arslan, M., 2008. Petrology and geochemistry of Tertiary volcanic rocks from the İkizce (Ordu) area, NE Turkey: implications for the evolution of the eastern Pontide paleo-magmatic arc. Journal of Asian Earth Sciences 31, 439-463.

Temizel, İ., Arslan, M., 2009. Mineral chemistry and petrochemistry of post-collisional Tertiary mafic to felsic cogenetic volcanics in the Ulubey (Ordu) area, eastern Pontides, NE Turkey. Turkish Journal of Earth Sciences 18, 29-53.

Temizel, İ., Arslan, M., Ruffet, G., Peucat, J.J., 2012. Petrochemistry, geochronology and Sr-Nd isotopic systematics of the Tertiary collisional and post-collisional volcanic rocks from the Ulubey (Ordu) area, eastern Pontide, NE Turkey: implications for extension-related origin and mantle source characteristics. Lithos 128, 126-147.

Temizel, İ., Arslan, M., Yücel, C., Abdioğlu, E., Ruffet, G., 2016. Geochronology and geochemistry of Eocene-aged volcanic rocks around the Bafra (Samsun, N Turkey) area: constraints for the interaction of lithospheric mantle and crustal melts, Lithos 258-259, 92-114. 
Thirlwall, M.F., Smith, T.E., Graham, A.M., Theodorou, N., Hollings, P., Davidson, J.P., Arculus, R.J., 1994. High field strength element anomalies in arc lavas; source or process? Journal of Petrology 35/3, 819-838.

Thompson, R.N., Morrison, M.A., Hendry, G.L., Parry, S.J., 1984. An assessment of the relative roles of crust and mantle in magma genesis: An elemental approach. Philosophical Transactions of the Royal Society of London A 310, 549-590.

Thomsen, T.B., Schmidt, M.W., 2008. Melting of carbonated pelites at 2.5-5.0 GPa, silicatecarbonatite liquid immiscibility, and potassium-carbon metasomatism of the mantle. Earth and Planetary Science Letters 267, 17-31.

Tokel, S., 1977. Doğu Karadeniz Bölgesinde Eosen yaşlı kalk-alkalen andezitler ve jeotektonizma [Eocene calc-alkaline andesites and geotectonism in Black Sea Region] Geol Soc Turk Bull 20, 49-54 (in Turkish with English abstract, unpublished).

Topuz, G., Altherr, R., Siebel, W., Schwarz, W.H., Zack, T., Hasözbek, A., Barth, M., Satır, M., Şen, C., 2010. Carboniferous high-potassium I-type granitoid magmatism in the Eastern Pontides: the Gümüşhane pluton (NE Turkey). Lithos 116, 92-110.

Topuz, G., Okay, A.İ, Altherr, R., Schwarz, W.H., Siebel, W., Zack, T., Satır, M., Şen, C., 2011. Postcollisional adakite-like magmatism in the Ağvanis Massif and implications for the evolution of the Eocene magmatism in the Eastern Pontides (NE Turkey). Lithos 125, 131-150.

Turner, G., 1971. ${ }^{40} \mathrm{Ar}-{ }^{39} \mathrm{Ar}$ ages from the lunar Maria. Earth Planetary Science Letters 11, 169-191.

Turner, S.P., 2005. Some remarks on magmatic processes beneath island arc volcanoes. Advances in Science, Earth Sciences. Imperial College Press, pp. 131-155.

Ustaömer, T., Robertson, A.H.F., 1996. Paleotethyan tectonic evolution of the North Tethyan margin in the central Pontides, N Turkey. In: Erler, A., Ercan, T., Bingöl, E., Örçen, S. (Eds.), International Symposium on the Geology of the Black Sea Region, Proceedings-I, 24-33.

Ustaömer, T., Robertson, A.H.F., 2010. Late Palaeozoic-Early Cenozoic tectonic development of the Eastern Pontides (Artvin area), Turkey: stages of closure of Tethys along the southern margin of Eurasia. In: Sosson, M., Kaymakci, N., Stephenson, R. A., Bergerat, F. \& Starostenko, V. (eds) Sedimentary Basin Tectonics from the Black Sea and Caucasus to the Arabian Platform. Geological Society of London, Special Publications 340, 281-327.

Varne, 1985. Ancient subcontinental mantle: A source for K-rich orogenic volcanics. Geology 13, 405-408.

Weaver, B.L., 1991. The origin of ocean island basalt end-member compositions: trace-element and isotopic constraints. Earth and Planetary Science Letters 104, 381-397.

Wendlandt, R.F., Eggler, D.H., 1980a. The origin of potassic magmas: 1. Melting relations in the systems $\mathrm{KAlSiO}_{4}-\mathrm{Mg}_{2} \mathrm{SiO}_{4}-\mathrm{SiO}_{2}$ and $\mathrm{KAlSiO}_{4}-\mathrm{MgO}-\mathrm{SiO}_{2}-\mathrm{CO}_{2}$ to $30 \mathrm{~kb}$. American Journal of Science 280, 385-420. 
Wendlandt, R.F., Eggler, D.H., 1980b. The origin of potassic magmas: 2. Stability of phlogopite in natural spinel lherzolite and in the system $\mathrm{KAlSiO}_{4}-\mathrm{MgO}-\mathrm{SiO}_{2}-\mathrm{H}_{2} \mathrm{O}-\mathrm{CO}_{2}$ at high pressure and high temperature. American Journal of Science 280, 421-458.

White, W.M., Hofmann, A.W., 1982. Sr and Nd isotope geochemistry of oceanic basalts and mantle evolution. Nature 296, 821-825.

White, W.M., Dupré, B., 1986. Sediment subduction and magma genesis in the Lesser Antilles: isotopic and trace element constraints. Journal of Geophysical Research 91, 5927-5941.

Wilson, M., 1989. Igneous Petrogenesis. Oxford University Press, Oxford, 369p.

Wilson, M., Tankut, A., Güleç, N., 1997. Tertiary volcanism of the Galatia Province, Central Anatolia, Turkey. Lithos 42, 105-121.

Wimmenauer, W., 1985. Petrography of Magmatic and Metamorphic Rocks. Stuttgart, Germany

Winter, J.D., (2001). An Introduction to Igneous and Metamorphic Petrology. Prentice Hall, New Jersey, 697p.

Woodhead, J.D., Hergt, J.M., Davidson, J.P., Eggins, S.M., 2001. Hafnium isotope evidence for 'conservative' element mobility during subduction zone processes. Earth and Planetary Science Letters 192, 331-346.

Workman, R.K., Hart, S.R., Jackson, M., Regelous, M., Farley, K.A., Blusztajn, J., Kurz, M., Staudigel, H., 2004. Recycled metasomatized lithosphere as the origin of the enriched mantle II (EM2) end-member: Evidence from the Samoan Volcanic Chain. Geochemistry, Geophysics, Geosystems 5(4): Q04008, doi:10.1029/2003GC000623.

Yang, W., Niu, H., Shan, Q., Luo, Y., Sun, W., Li, C., Li, N., Yu, X., 2012. Late Paleozoic calcalkaline to shoshonitic magmatism and its geodynamic implications, Yuximolegai area, western Tianshan, Xinjiang. Gondwana Research 22, 325-340.

Y1lmaz, Y., 1972. Petrology and structure of the Gümuşhane granite and surrounding rocks, Northeastern Anatolia. PhD Thesis, University of London, 260p.

Yılmaz, Y., Tüysüz, O., Yiğitbaş, E., Genç, Ş.C., Şengör, A.M.C., 1997. Geology and tectonics of the Pontides. In: Robinson AG (ed) Regional and petroleum geology of the Black Sea and surrounding region. Memoirs of American Association of Petroleum Geologists 68, 183-226.

Yücel, C., Arslan, M., Temizel, İ., Abdioğlu, E., Ruffet, G., 2012. Whole rock petrochemistry and ${ }^{40} \mathrm{Ar}-{ }^{39} \mathrm{Ar}$ geochronology of the Tertiary alkaline volcanics between Trabzon and Giresun areas, NE Turkey. 65th geological congress of Turkey abstracts book, pp 354-355.

Yücel, C., Arslan, M., Temizel, İ., Abdioğlu, E., 2014a. Volcanic facies and mineral chemistry of Tertiary volcanics in the northern part of the Eastern Pontides, northeast Turkey: implications for pre-eruptive crystallization conditions and magma chamber processes. Mineralogy and Petrology 108-3, 439-467.

Zhao, Z.D., Mo, X.X., Dilek, Y., Niu, Y.L., DePaolo, D.J., Robinson, P., Zhu, D.C., Sun, C.G., Dong, G.C., Zhou, S., Luo, Z.H., Hou, Z.Q., 2009. Geochemical and Sr-Nd-Pb-O isotopic 
compositions of the post-collisional ultrapotassic magmatism in SW Tibet: Petrogenesis and implications for India intra-continental subduction beneath southern Tibet. Lithos 113, 190-212. Zindler, A., Hart, S.R., 1986. Chemical geodynamics. Annual Review of Earth and Planetary Sciences $14,493-571$ 


\section{Figure Captions}

Figure 1. (a) The inset map shows the tectonic unit of Turkey (Okay and Tüysüz, 1999). (b) Generalized geological map of the Eastern Pontides showing distribution of the Tertiary volcanic rocks and intrusions (modified after Güven, 1993; Arslan et al., 2013). The square indicates the study area. (c) Geological map of the study area showing distribution of the Eocene and Miocene volcanic rocks (modified from Güven (1993) and Late Cretaceous units modified from Kurt et al. (2006)).

Figure 2. Distribution of apparent ages acquired by step heating of whole-rock, phlogopite and sanidine fractions of (a) the Eocene basaltic and trachytic, and (b) the Miocene tephrytic rocks (AP is apparent age).

Figure 3. Classification of the Eocene and Miocene volcanic rocks from the Trabzon and Giresun areas based on the (a) $\mathrm{Na}_{2} \mathrm{O}+\mathrm{K}_{2} \mathrm{O}$ (wt.\%) vs $\mathrm{SiO}_{2}$ (wt.\%) diagram (Le Bas et al., 1986), (b) Th (ppm) vs $\mathrm{Co}$ (ppm) diagram (Hastie et al., 2007), (c) $\mathrm{K}_{2} \mathrm{O} / \mathrm{Na}_{2} \mathrm{O}$ vs $\Delta \mathrm{Q}$ diagram (Peccerillo, 2002, 2003), (d) AFM ternary diagram tholeitic- alkaline-calc-alkaline- shoshonitic dividing lines from Wimmanuer (1985), (e, f) $\mathrm{CaO}$ (wt.\%) vs $\mathrm{Al}_{2} \mathrm{O}_{3}$ and $\mathrm{MgO}$ classification diagrams of Foley et al. (1987). ( $\Delta \mathrm{Q}$ is the algebraic sum of normative quartz (q) minus undersaturated minerals leucite (lc), nepheline (ne), kalsilite (kal) and olivine (ol)).

Figure 4. Major oxides (wt. \%) Harker variation diagram plotted against $\mathrm{SiO}_{2}$ (wt. \%) of the Eocene and Miocene volcanic rocks from the Trabzon and Giresun areas (symbols are as in Fig. 3)

Figure 5. Primitive mantle (Sun and McDonough, 1989) multi element spider and chondrite (Taylor and McLennan, 1985) normalized rare earth element diagrams of the Eocene and Miocene volcanic rocks from the Trabzona and Giresun areas.

Figure 6. (a) $\left({ }^{143} \mathrm{Nd} /{ }^{144} \mathrm{Nd}\right)_{i}$ versus $\left({ }^{87} \mathrm{Sr} /{ }^{86} \mathrm{Sr}\right)_{i}$ diagram showing the Eocene and Miocene volcanic rocks from Trabzon and Giresun areas with the samples from other alkaline and calc-alkaline volcanic rocks of Borçka volcanic rocks (Aydınçakır and Şen, 2013), Torul volcanic rocks (Kaygusuz et al., 2011), Eastern Pontides Southern part Eocene volcanic rocks (Arslan et al., 2013), Everek Hanlar1 volcanic rocks (Alther et al., 2008; Eyüboğlu, 2010), Ulubey volcanic rocks (Temizel et al., 2012), Kop Adakites (Eyuboglu et al., 2013), Kale Adakites (Karslı et al., 2010). Data for lithospheric mantle array from Davies and von Blanckenburg (1995). Compositions of MORB (mid-ocean ridge basalt) and mantle array from Wilson (1989), Gill (1981) and McCulloch et al. (1994); EMI (enriched mantle type I) and EMII (enriched mantle type II), HIMU(high $\mu v$ : mantle with high U/Th ratio), DM (Depleted Mantle) fields and CHUR (Chondritic Uniform Reservoir)-Sr and -Nd reference lines after Zindler and Hart (1986). (b,c) variations in $\mathrm{Pb}$ isotope compositions of samples from Eocene and Miocene alkaline volcanic rocks from Trabzon-Giresun areas. Plotted for comparison, the composition of pelagic sediments and MORB are after Peate et al. (1997) and Hofmann (2003), NHRL (Northern Hemisphere Reference Line) after Hart (1984), EAR (Depleted East European Lithosphere) after Rosenbaum et al. (1997), North African sediments after Pe-Piper (1994), DM (depleted mantle), HIMU and enriched (EMI and EMII) mantle after Zindler and Hart (1986). Field of arc systems (compiled in Wilson, 1989; Winter, 2001)

Figure 7. (a) Sc vs. Rb (for the Eocene basaltic rocks), (b) Sr vs. Dy (for the Eocene trachytic rocks), (c) Sc vs. Nb (for the Miocene tephrytic rocks) diagrams displaying theoretical Rayleigh fractionation lines. The FC-Modeller program of Keskin (2002) was used to calculate the plot of line. Kd values of 
$\mathrm{Rb}, \mathrm{Sc}, \mathrm{Sr}, \mathrm{Nb}, \mathrm{Dy}$ and $\mathrm{Sr}$ for amphibole, plagioclase, clinopyroxene, olivine, biotite and sanidine were compiled from Rollinson (1993), GERM Partition Coefficient (Kd) Database of Earth Reference Data and Models website (http://earthref.org/; see the references therein) and Keskin (2002). amp: amphibole; pl: plagioclase; ol: olivine; bio: biotite; cpx: clinopyroxene; Sa: sanidine (symbols are as in Fig. 3).

Figure 8. (a) $\left({ }^{87} \mathrm{Sr} /{ }^{86} \mathrm{Sr}\right)_{\mathrm{i}}$ versus $\mathrm{Nb} / \mathrm{Ta}$, (b) $\left({ }^{87} \mathrm{Sr} /{ }^{86} \mathrm{Sr}\right)_{\mathrm{i}}$ versus $\mathrm{Sr}(\mathrm{ppm})$, (c) $\left({ }^{87} \mathrm{Sr} /{ }^{86} \mathrm{Sr}\right)_{\mathrm{i}}$ versus $\mathrm{SiO}_{2}$ (wt.\%) (d) $\left({ }^{143} \mathrm{Nd} /{ }^{144} \mathrm{Nd}\right)_{\mathrm{i}}$ versus $\mathrm{Sm} / \mathrm{Nd}$, (e) $\left({ }^{143} \mathrm{Nd} /{ }^{144} \mathrm{Nd} \text { ) }\right)_{i}$ versus $\mathrm{Nb}$ (ppm), (f) ${ }^{207} \mathrm{~Pb} /{ }^{204} \mathrm{~Pb}$ versus $\mathrm{MgO}$ (wt.\%) diagrams showing possible fractional crystallization (FC) and/or assimilation-fractional crystallization (AFC) trends for the Eocene and Miocene volcanic rocks from the Trabzon and Giresun areas (symbols are as in Fig. 3).

Figure 9. $(\mathrm{a}, \mathrm{b})\left({ }^{87} \mathrm{Sr} /{ }^{86} \mathrm{Sr}\right)_{\mathrm{i}}$ versus $\left({ }^{143} \mathrm{Nd} /{ }^{144} \mathrm{Nd}\right)_{\mathrm{i}}$ diagrams $(\mathrm{g}, \mathrm{h}$, using Paleozoic aged granite $(\mathrm{T} 135)$ from Kaygusuz et al. (2012) and limestone (ERN57) from Boari et al. (2009) as a upper crustal assimilant, respectively) showing isotopic AFC (assimilation-fractional crystallization) for the Eocene and Miocene volcanic rocks from the Trabzon and Giresun areas. The representative AFC curves are for various combinations of a volcanic arc basalt as hypothetical parental magma (K-93-56, Alic1 et al., 2002) and bulk distribution coefficients $\left(D_{S r}, D_{N d}\right)$. Tick marks indicate the ratio of the final mass of magma to its initial mass (F) and are given in intervals of $5 \%$ and $10 \%$ to a maximum of $95 \%(r=$ 0.2 and 0.3 for figure a curves $r=0.3$ for figure $\mathrm{b}$ curves). Other parameters are indicated in the Table 6 (symbols are as in Fig. 3)

Figure 10. (a) Plot of $\mathrm{Yb}$ vs. $\mathrm{La} / \mathrm{Yb}$ for the Eocene and Miocene volcanic rocks from the Trabzon and Giresun areas. Non-modal batch melting curves were calculated by using partition coefficients from Rollinson (1993), McKenzie and O'Nions (1991) and Keskin (2002). (b) $\mathrm{Rb} / \mathrm{Sr}$ vs Ba/Rb diagram for the Eocene and Miocene volcanic rocks from the Trabzon and Giresun areas (symbols are as in Fig. 3).

Figure 11. The importance of sediment or fluid like metasomatism in the petrogenesis of the Eocene and Miocene volcanic rocks from the Trabzon and Giresun areas; (a) the plot of $\mathrm{Ba} / \mathrm{Th}$ vs. Th (ppm), the shaded areas represent the arc volcanic rocks worldwide. (b) $\mathrm{Th} / \mathrm{Yb}$ vs. $\mathrm{Ba} / \mathrm{La}$ diagram, the shaded areas indicate the oceanic arc volcanic rocks (Kirchenbaur et al. (2012) and references therein). The plot of (c) Sr/La vs. La/Yb, (symbols are as in Fig. 3).

Figure 12. (a) $\left.{ }^{87} \mathrm{Sr} /{ }^{86} \mathrm{Sr}\right)$ i versus ${ }^{206} \mathrm{~Pb} /{ }^{204} \mathrm{~Pb}$, and (b) $\varepsilon \mathrm{Nd}_{\mathrm{i}}$ versus ${ }^{206} \mathrm{~Pb} /{ }^{204} \mathrm{~Pb}$ diagrams showing a threecomponent mixing model between upper/lower crust and upper mantle for the Eocene and Miocene volcanic rocks from the Trabzon and Giresun areas. Tick marks on mixing lines are at $10 \%$ intervals and the parameters for the mixing calculation are presented in Table 7 (symbols are as in Fig. 3).

Figure 13. Schematic cartoons showing the favoured geodynamic model for the Eocene and Miocene volcanism in the Eastern Pontides, accompanied by post-collisional extension regime due to delamination of lithosphere: (a) post-collisional extensional stage due to delamination, forming the Eocene volcanism (ca.50-45 Ma, Arslan et al., 2013), (b) schematic illustration of partial melting and pre-eruptive crystallization paths and magmatic processes in crustal chambers for Eocene volcanism, (c) ongoing post-collisional extensional stage, forming Miocene-Pliocene volcanism (ca. 15-5 Ma, Arslan et al., 2013), (d) schematic illustration of partial melting and pre-eruptive crystallization paths and magmatic processes in crustal chambers for Miocene volcanism. 
Figure 14. (a) Full horizontal-gradient amplitude map calculated from Bouguer gravity data of the Eastern Pontide Orogenic Belt. Colour bar at top indicates interval values. Colour levels indicate horizontal gradient intensity from white (lowest) to black (highest). Heavy black lines indicate major gravity lineaments. Narrow black lines represent lithological and structural boundaries, (b) Tectonic map of the Trabzon and surrounding area (modified after Kaygusuz et al. (2012), Arslan et al. (2013) and Yücel et al. (2014a)) and geometry of an idealised tension gash in left lateral strike-slip fault. Theoretical distribution of tensional fractures $(T)$ and shear fractures $\left(R, R^{\prime}\right.$ and $P$ ) in the same kinematical framework. (1) Palaeozoic granitoids, (2) Liassic- Dogger volcanic rocks, (3) MalmLower Cretaceous sedimentary rocks, (4) Late Cretaceous volcanic rocks, (5) Late Cretaceous granitoids, (6) Eocene volcanic rocks (7) Eocene granitoids, (8) Miocene volcanic rocks, (9) Pliocene sedimentary rocks. 


\section{Table Captions}

Table 1. ${ }^{40} \mathrm{Ar}-{ }^{39} \mathrm{Ar}$ age spectrum of the Eocene and Miocene volcanic rocks from the Trabzon and Giresun areas.

Table 2. Sr and Nd isotopic analysis of the Eocene and Miocene volcanic rocks from the Trabzon and Giresun areas.

Table 3. $\mathrm{Pb}$ isotopic analysis of the Eocene and Miocene volcanic rocks from the Trabzon and Giresun areas.

Table 4. Compiled Kd values used in fractional crystallization (FC) modelling calculation.

Table 5. $\left({ }^{143} \mathrm{Nd} /{ }^{144} \mathrm{Nd}\right)_{\mathrm{i}},\left({ }^{87} \mathrm{Sr} /{ }^{86} \mathrm{Sr}\right)_{\mathrm{i}}, \mathrm{Sr}(\mathrm{ppm})$ and $\mathrm{Nd}(\mathrm{ppm})$ compositions assumed for the end member components in the AFC calculation.

Table 6. Partition coefficient $(D)$, normative weight fractions of minerals and source modal composition data used in partial melting modelling calculation.

Table 7. The compositions assumed for the end member (upper mantle, upper crust, lower crust) components of $\mathrm{Sr}-\mathrm{Nd}-\mathrm{Pb}$ isotopic mixing model. 


\section{Supplementary Figure Captions}

Supplementary Figure 1. ${ }^{40} \mathrm{Ar}-{ }^{39} \mathrm{Ar}$ Age spectra and plateau and inverse isochrones ages acquired by step heating of whole-rock, phlogopite and sanidine fractions of the Eocene and Miocene volcanic rocks from the Trabzon and Giresun areas. The age error bars for each temperature steps are at the $1 \mathrm{r}$ level and do not include errors in the J-values. The errors in the J-values $(0.2 \%)$ are included in the plateau age calculations.

Supplementary Figure 2. Trace (ppm) and rare earth element (ppm) Harker variation diagram plotted against $\mathrm{SiO}_{2}$ (wt. \%) of the Eocene and Miocene volcanic rocks from the Trabzon and Giresun areas (symbols are as in Fig. 3) 


\section{Supplementary Table Captions}

Supplementary Table 1. Analytical data and parameters used for calculations (isotopic ratios measured on $\mathrm{K}, \mathrm{Ca}$ and $\mathrm{Cl}$ pure salts; mass discrimination; atmospheric argon ratios; $\mathrm{J}$ parameter; decay constants) and reference sources for the studied Eocene and Miocene volcanic rocks.

Supplementary Table 2. The major and trace element composition of the studied Eocene and Miocene volcanic rocks. 

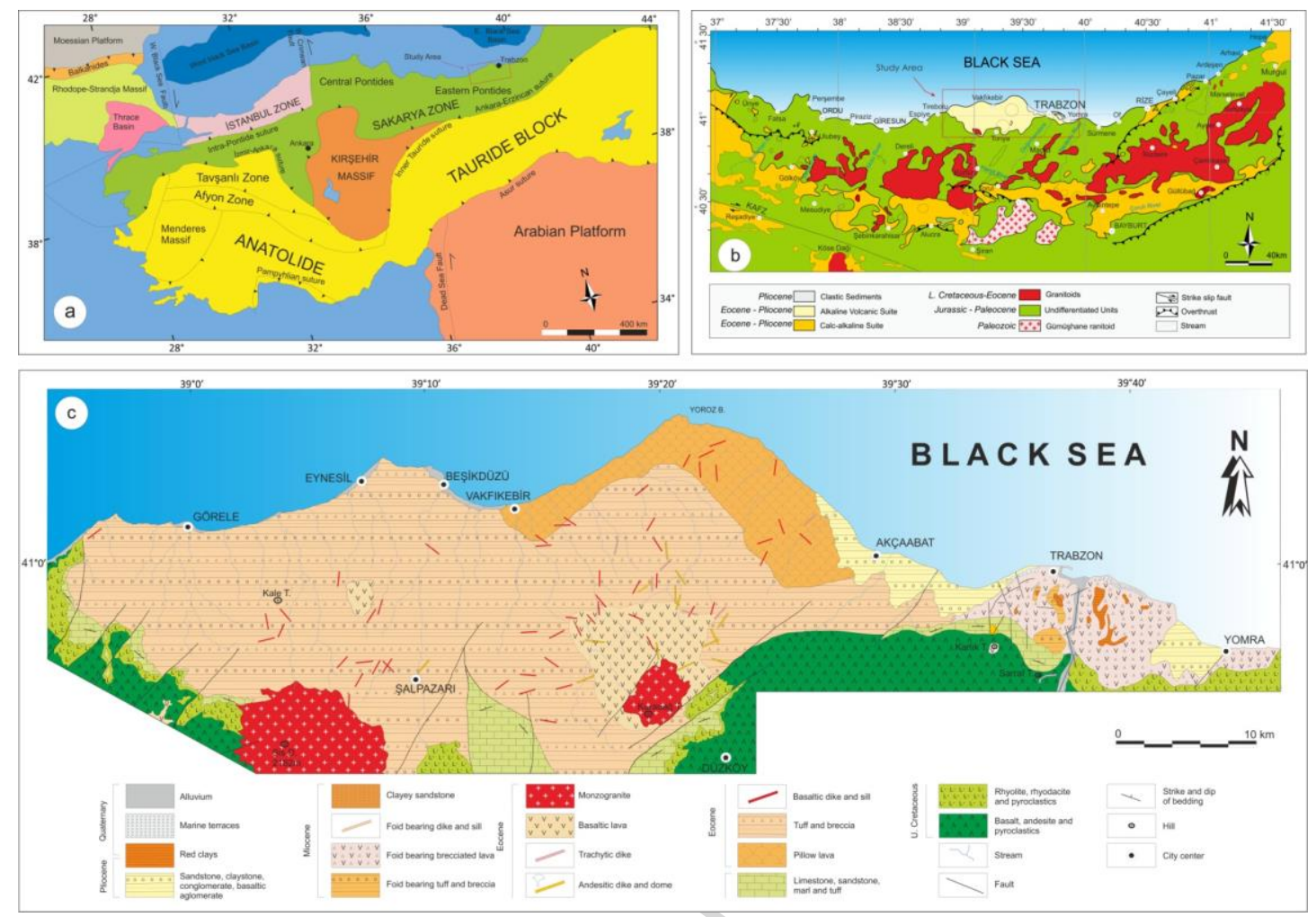

Figure 1 

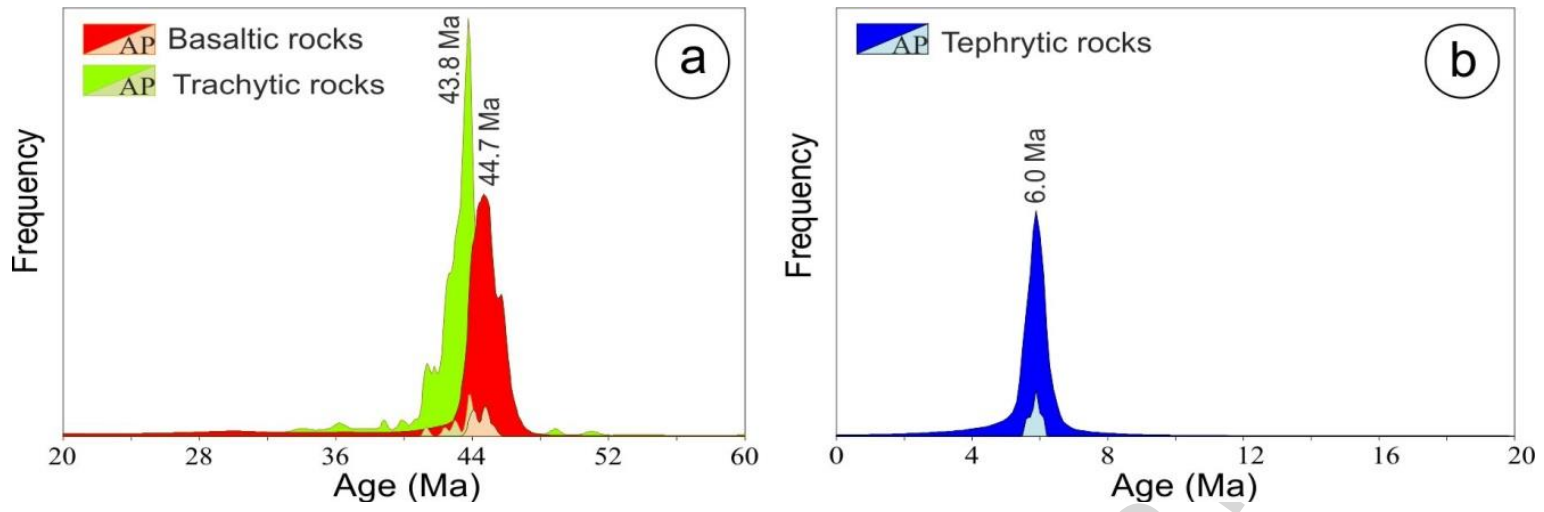

Figure 2 

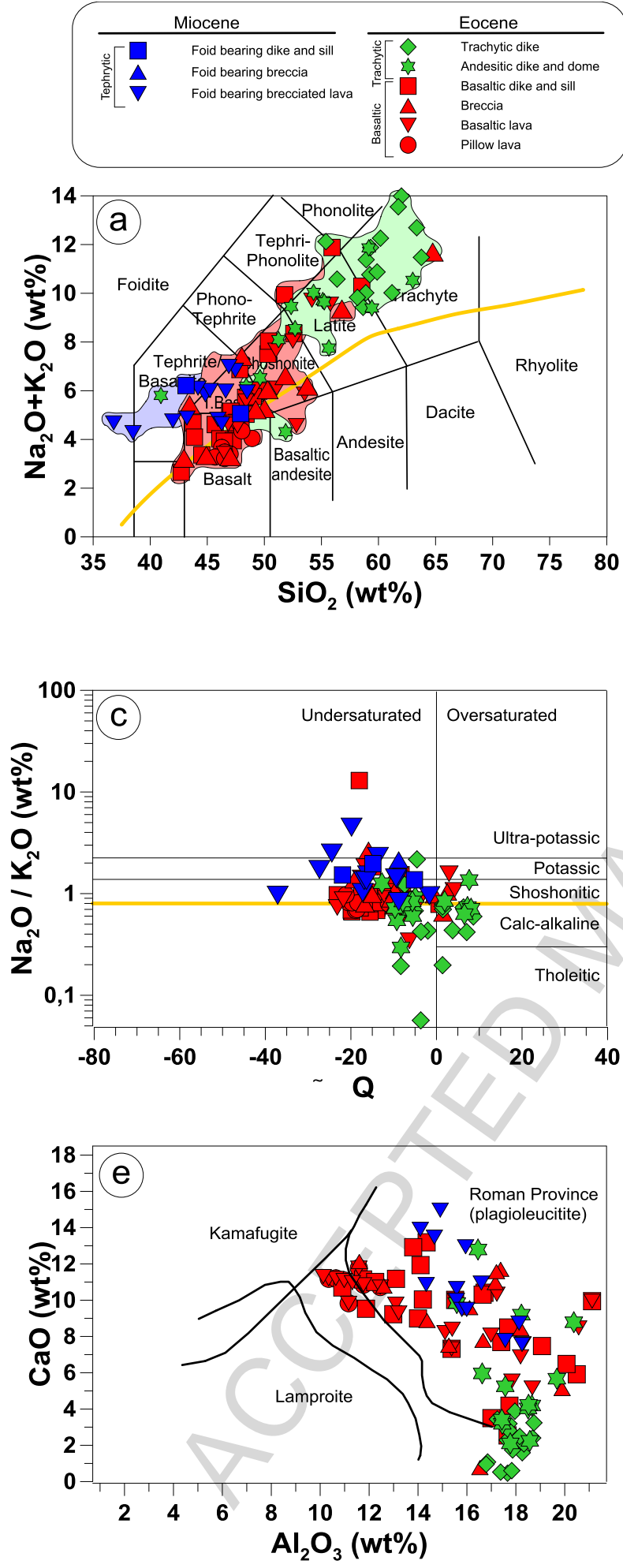
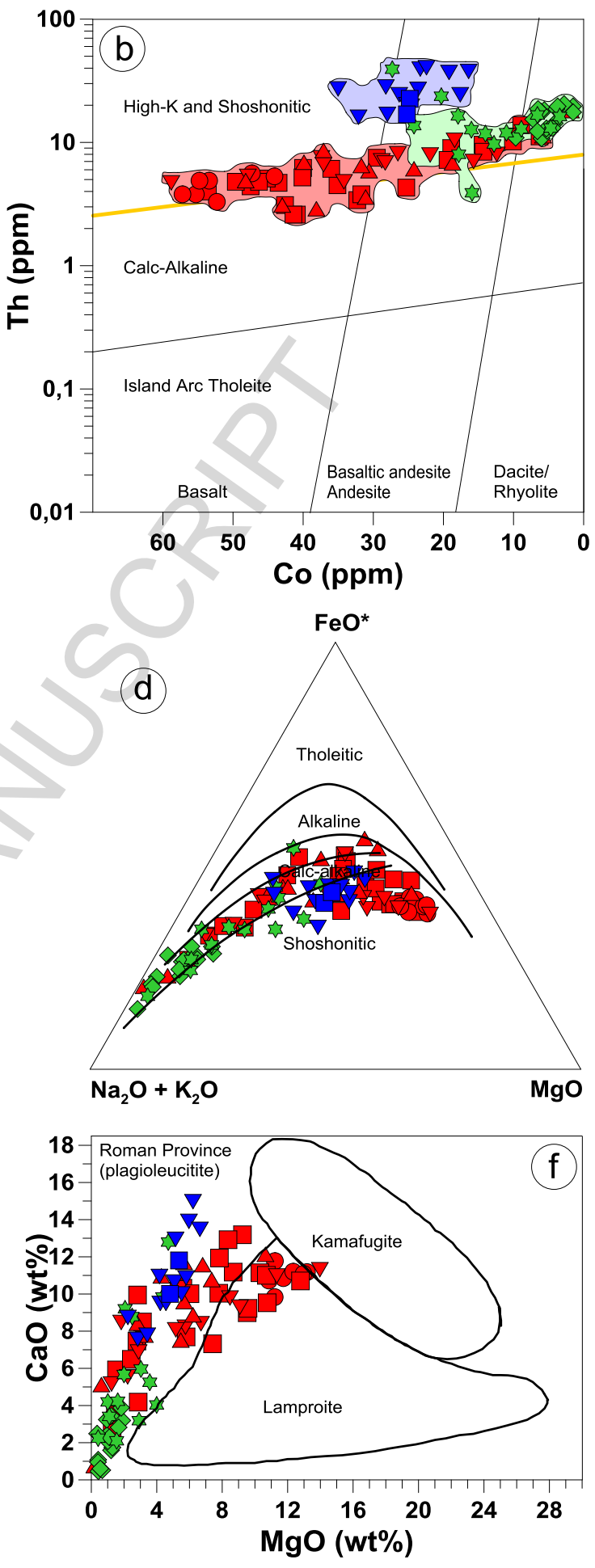

Figure 3 

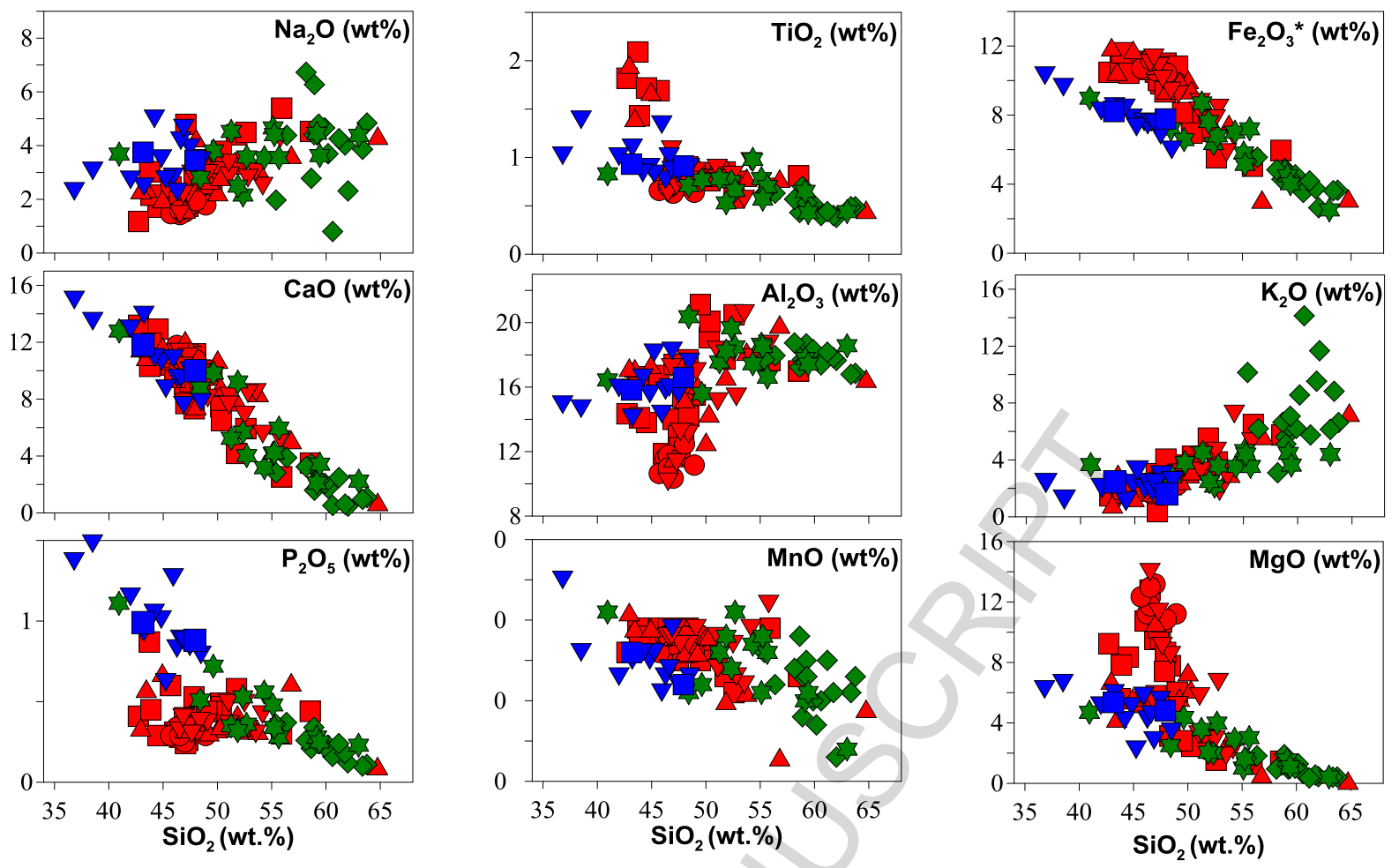

Figure 4 

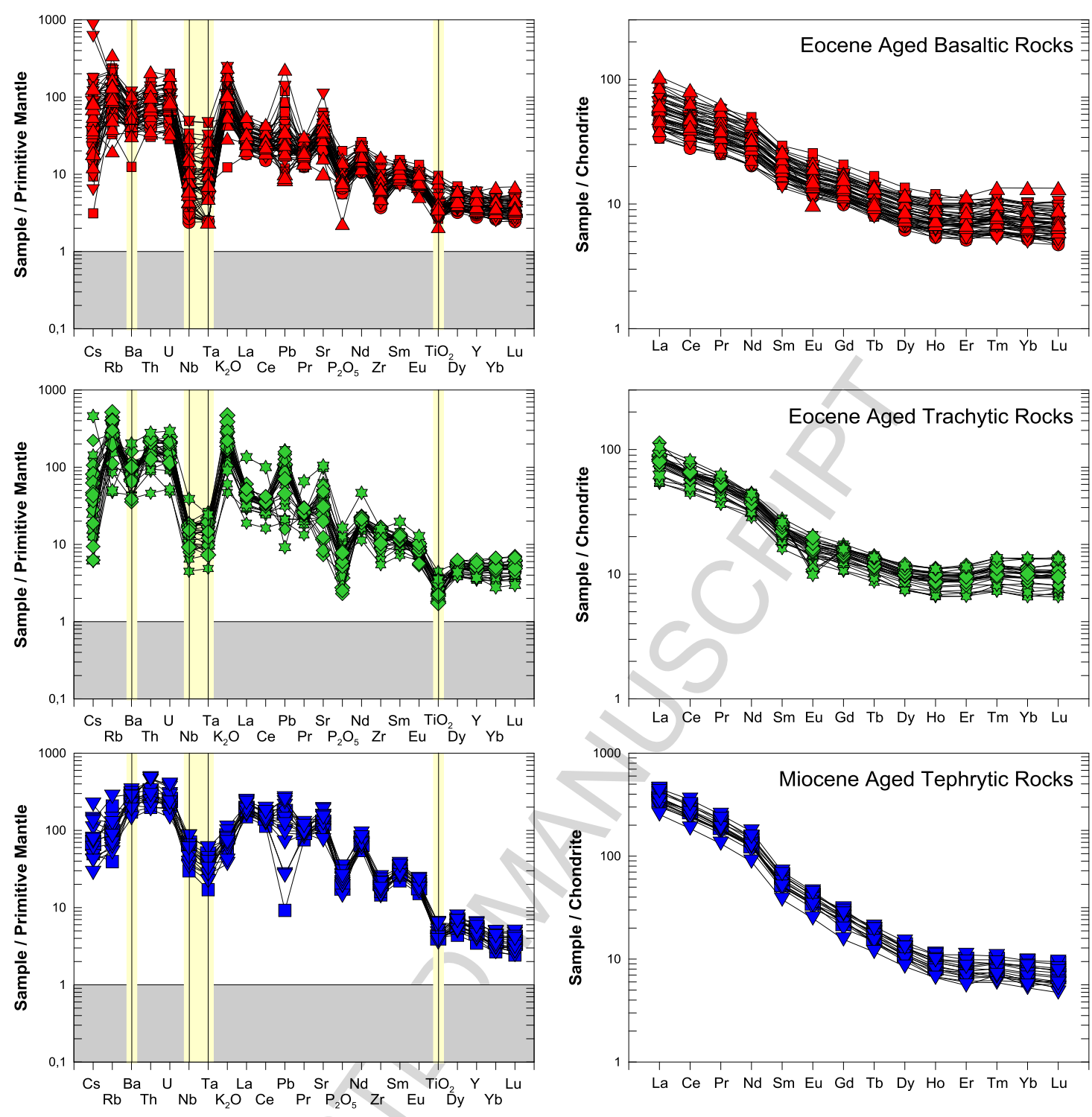

Figure 5 

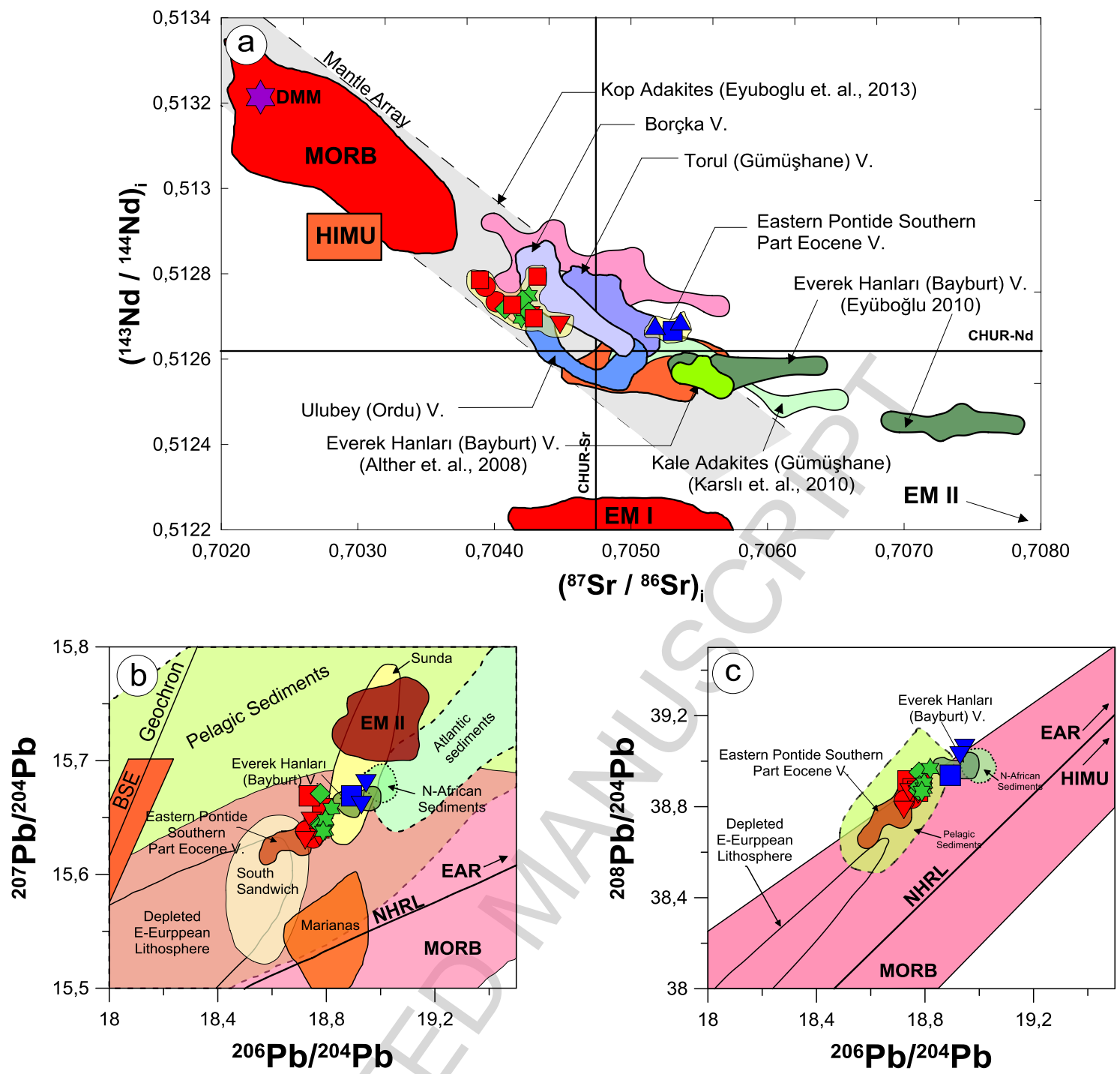

Figure 6 

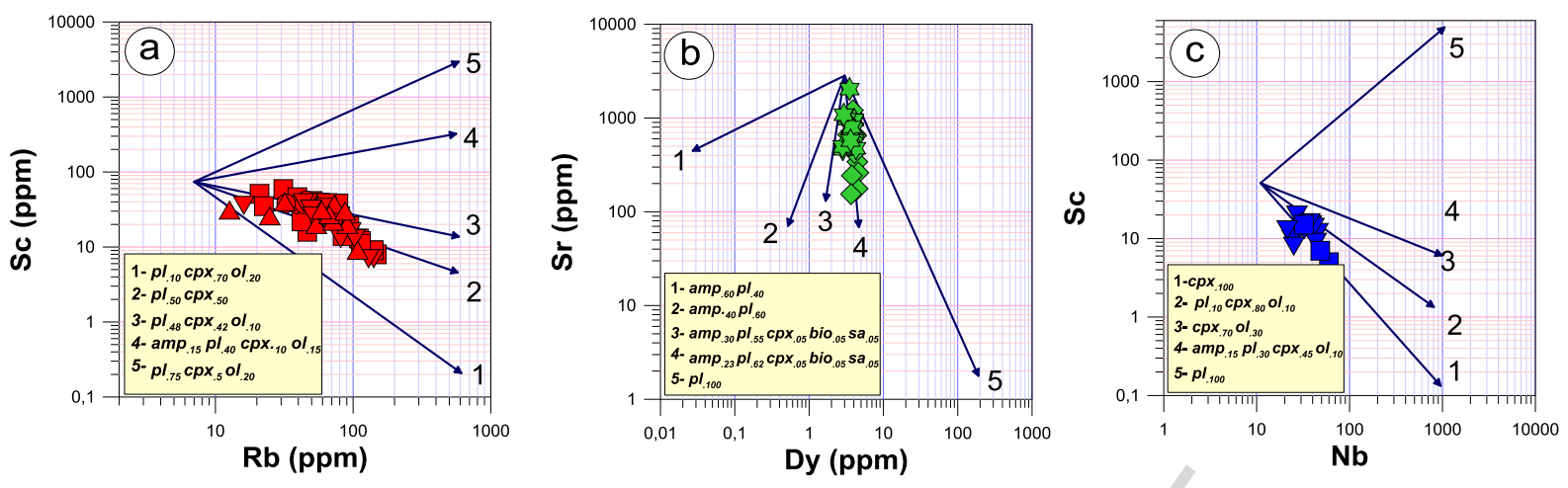

Figure 7 

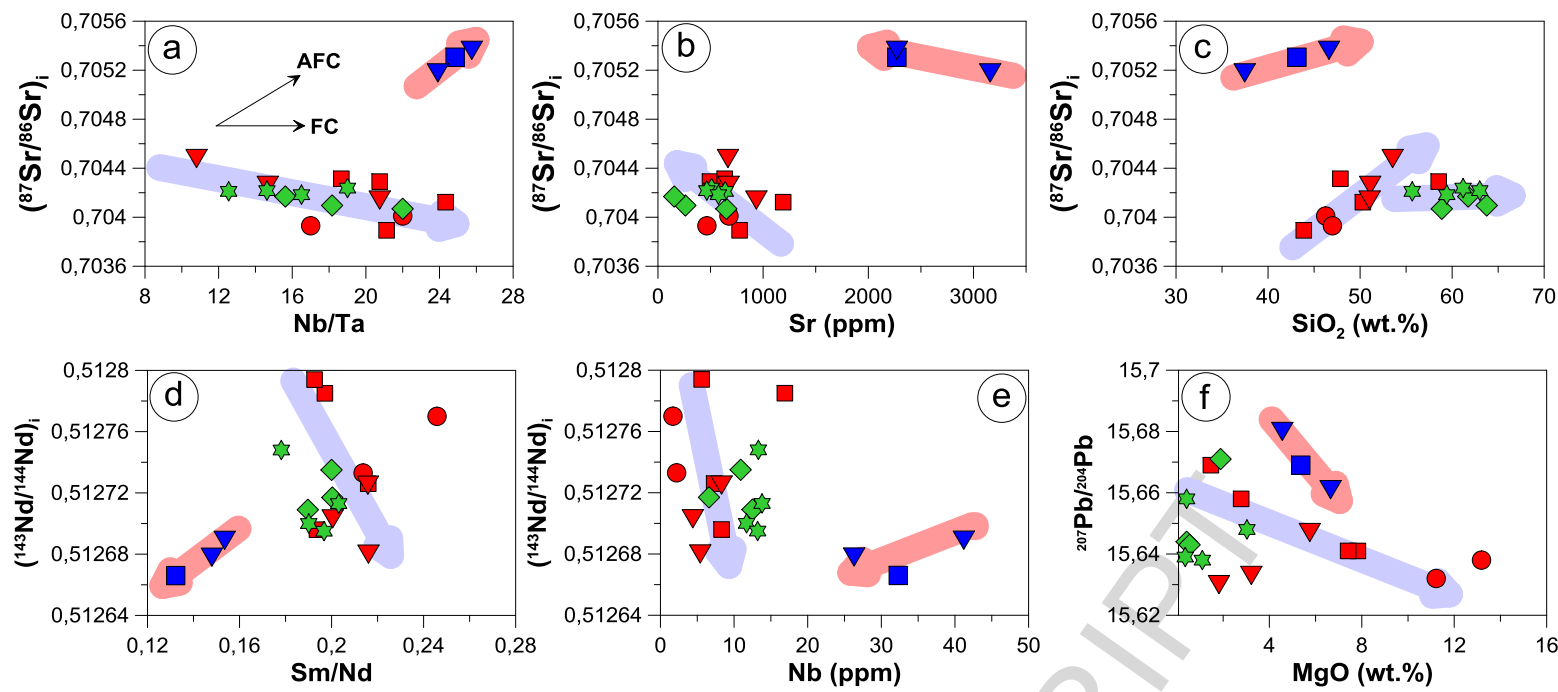

Figure 8 

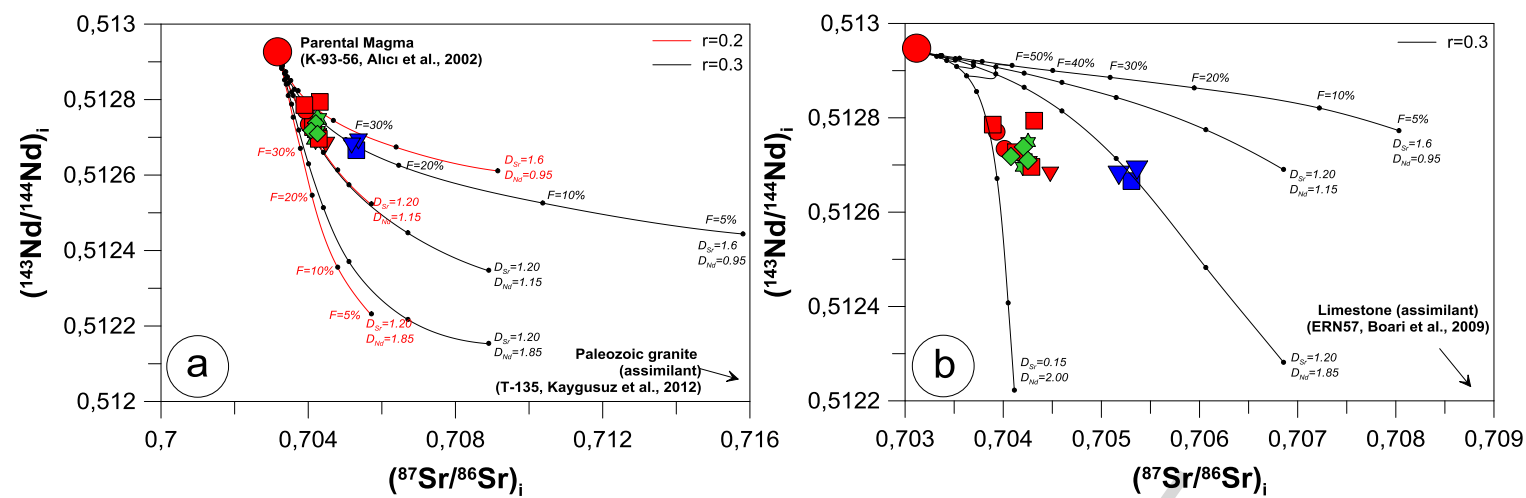

Figure 9 

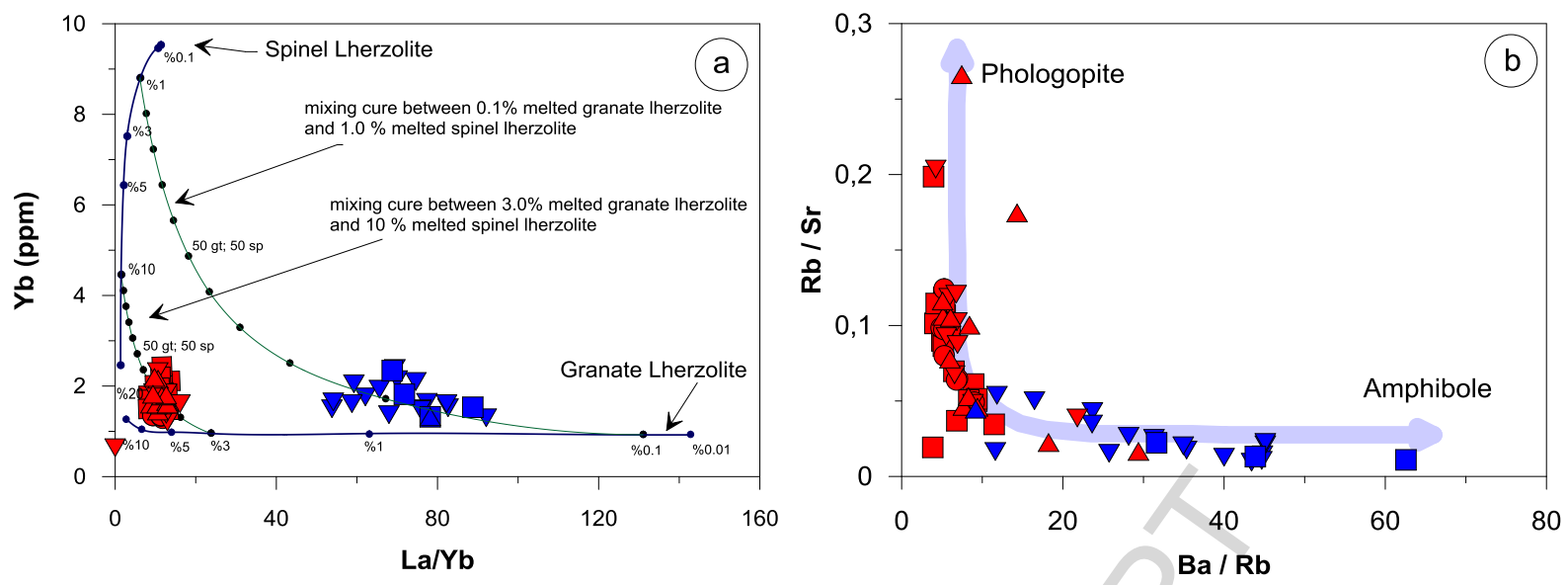

Figure 10 

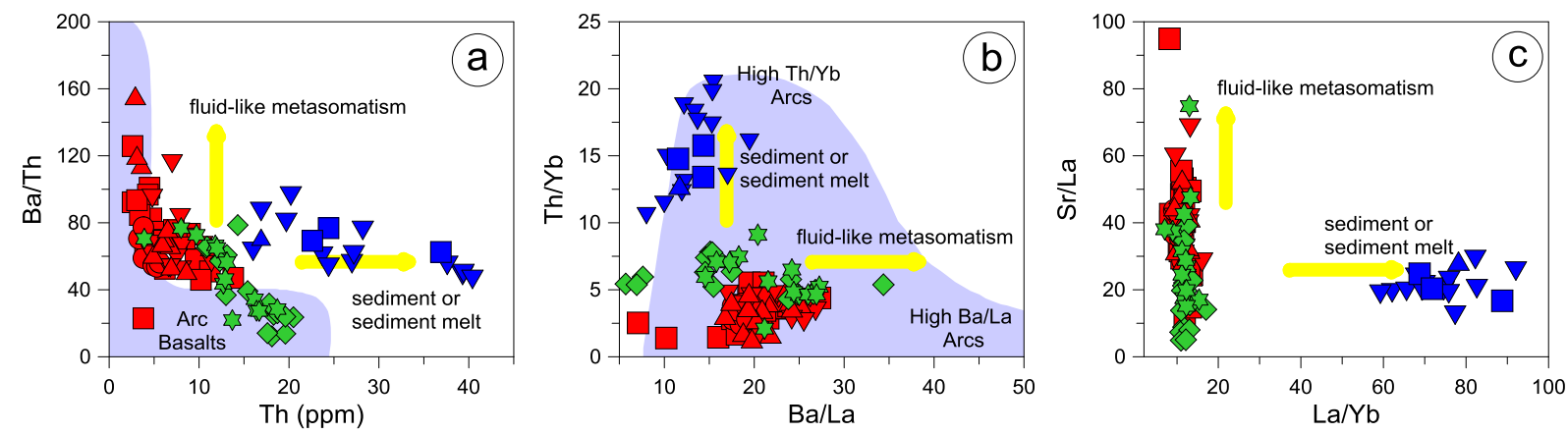

Figure 11 

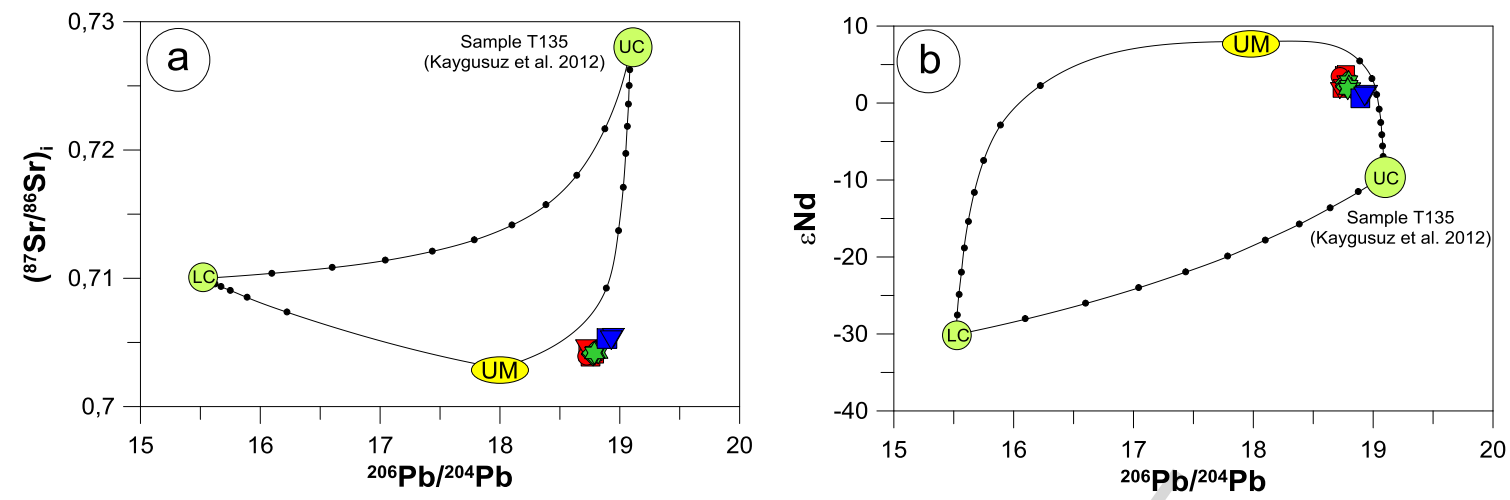

Figure 12 


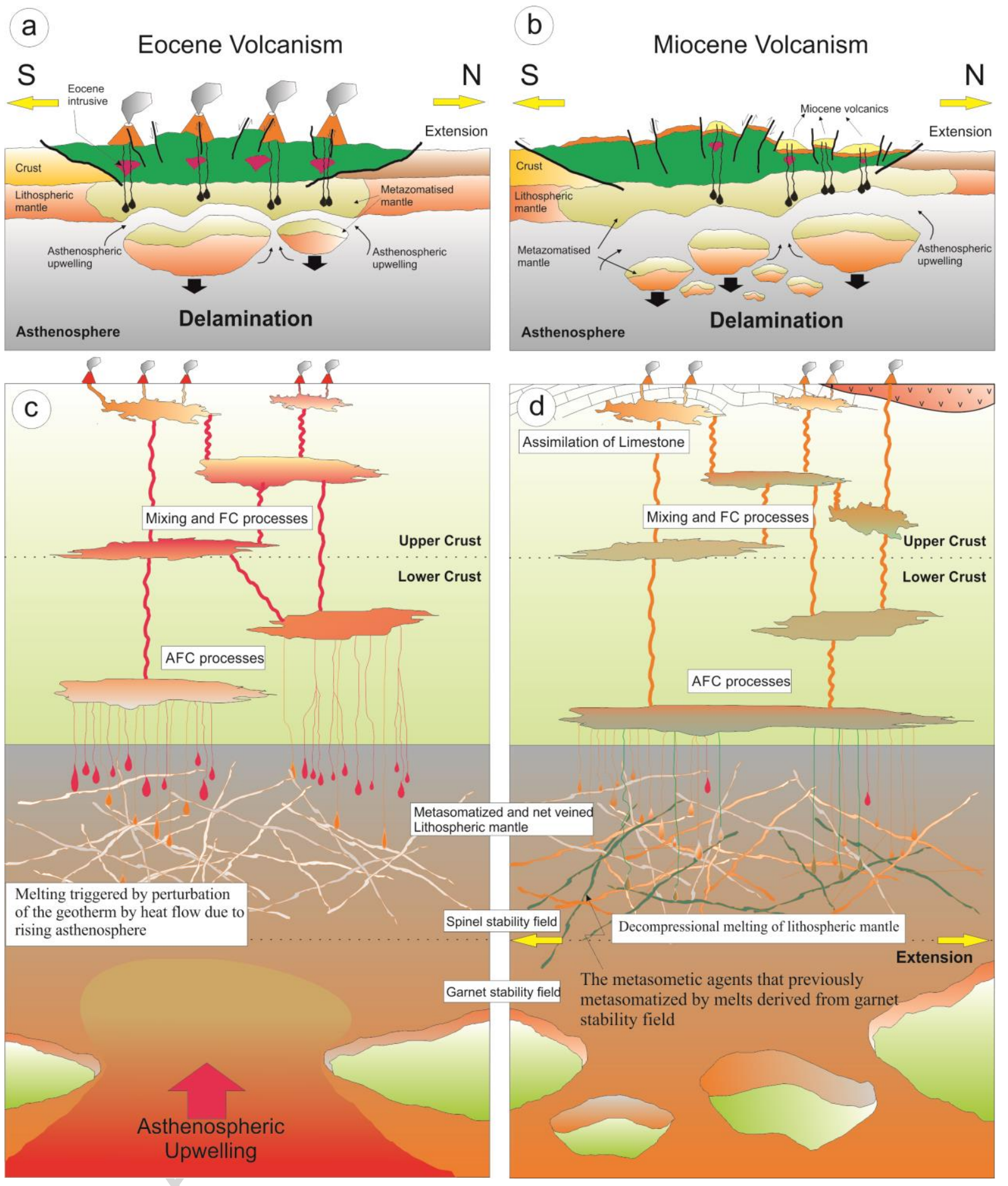

Figure 13 

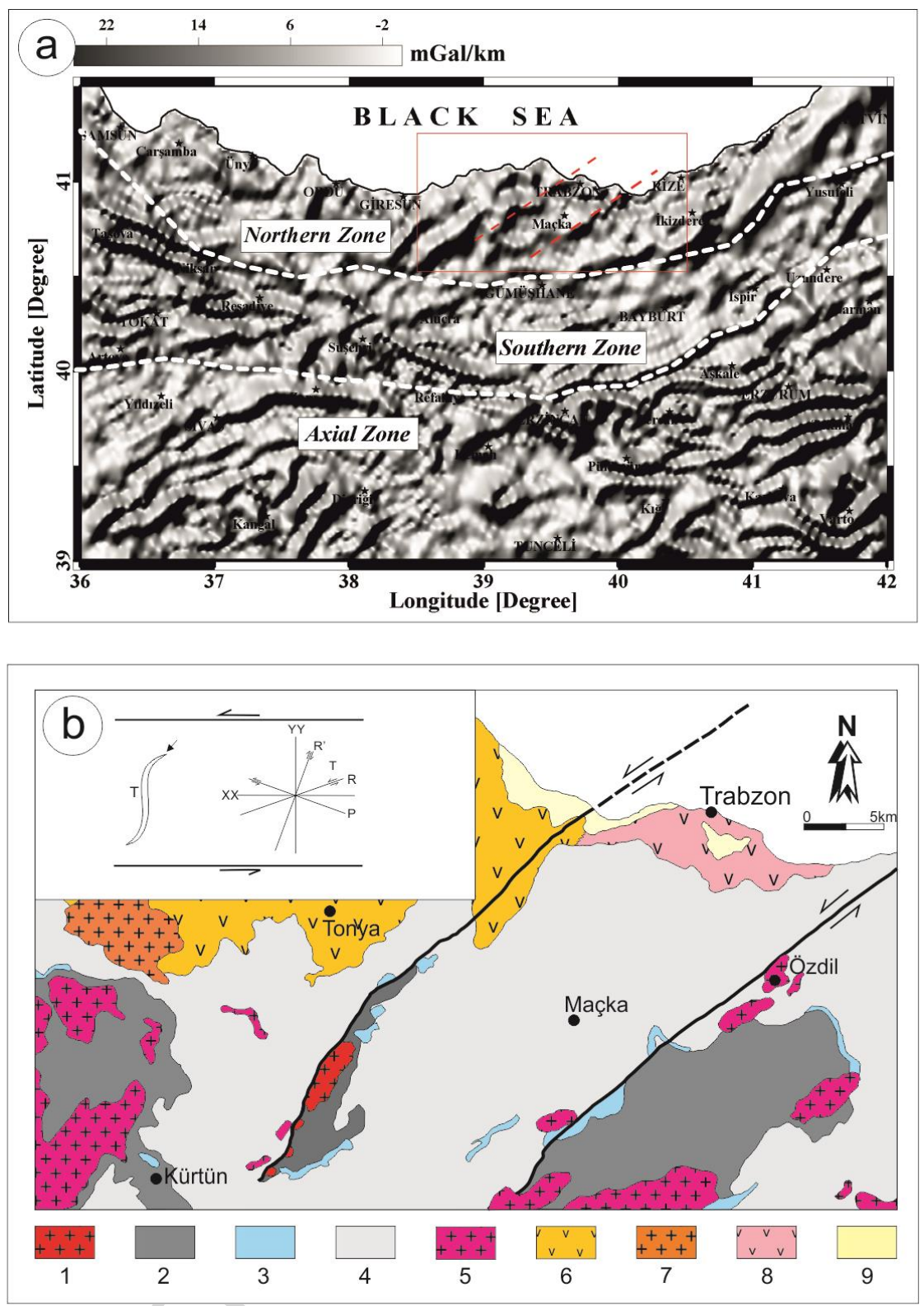

Figure 14 


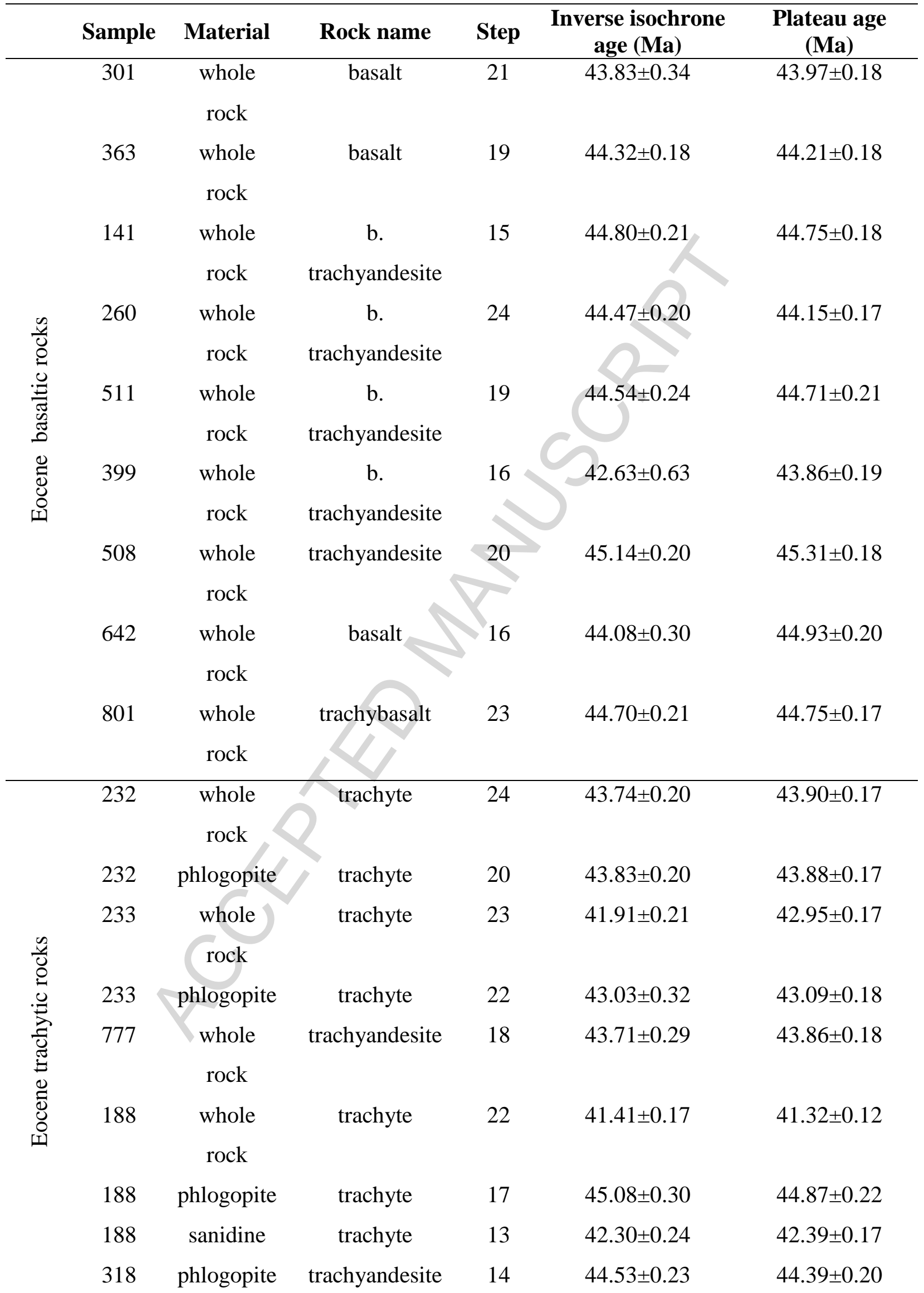




\begin{tabular}{|c|c|c|c|c|c|c|}
\hline & 318 & whole & trachyandesite & 22 & $43.96 \pm 0.18$ & $43.75 \pm 0.16$ \\
\hline & & rock & & & & \\
\hline & 625 & whole & trachyte & 26 & $43.77 \pm 0.20$ & $43.90 \pm 0.17$ \\
\hline & & rock & & & & \\
\hline & 625 & phlogopite & trachyte & 22 & $44.70 \pm 0.19$ & $44.62 \pm 0.18$ \\
\hline \multirow{5}{*}{ 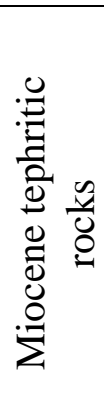 } & 603 & whole & tephrite & 14 & $5.98 \pm 0.13$ & $5.87 \pm 0.06$ \\
\hline & & rock & & & & \\
\hline & 603 & phlogopite & tephrite & 15 & 06 & $5.87 \pm 0.06$ \\
\hline & 721 & whole & tephrite & 15 & $6.07 \pm 0.06$ & $6.05 \pm 0.06$ \\
\hline & 802 & phlogopite & tephrite & 19 & $5.46 \pm 0.21$ & $5.65 \pm 0.06$ \\
\hline
\end{tabular}


Table 2

\begin{tabular}{|c|c|c|c|c|c|c|c|c|c|c|c|c|c|c|c|c|}
\hline & $\begin{array}{c}\text { Sa } \\
\text { mpl } \\
\text { e }\end{array}$ & $\begin{array}{c}\mathbf{R b} \\
(\mathbf{p} \\
\mathbf{p m} \\
)\end{array}$ & $\begin{array}{l}\text { Sr } \\
\text { (pp } \\
\text { m) }\end{array}$ & $\begin{array}{l}{ }^{87} \mathrm{Rb} \\
{ }^{86} \mathrm{Sr}\end{array}$ & $\begin{array}{l}{ }^{87} \mathrm{Sr} / \\
{ }^{86} \mathrm{Sr}\end{array}$ & $\begin{array}{l}( \pm 2 \\
\left.\sigma_{m}\right)\end{array}$ & $\begin{array}{l}\left({ }^{87} \mathrm{Sr} /\right. \\
\left.{ }^{86} \mathrm{Sr}\right)_{\mathrm{i}}\end{array}$ & $\begin{array}{c}\text { Sm } \\
(\mathbf{p} \\
\text { pm } \\
\text { ) }\end{array}$ & $\begin{array}{c}\text { Nd } \\
(\mathbf{p} \\
\text { pm } \\
)\end{array}$ & ${ }^{147} \mathrm{Sm} /$ & $\begin{array}{c}{ }^{143} \mathrm{Nd} / \\
{ }^{144} \mathrm{Nd}\end{array}$ & $\begin{array}{l}( \pm 2 \\
\left.\sigma_{m}\right)\end{array}$ & $\begin{array}{l}\left({ }^{143} \mathrm{Nd} /\right. \\
\left.{ }^{144} \mathrm{Nd}\right)_{\mathrm{i}}\end{array}$ & $\begin{array}{l}\varepsilon \mathbf{N} \\
\mathbf{d}(\mathbf{0})\end{array}$ & $\begin{array}{l}\varepsilon \mathbf{N} \\
d(t)\end{array}$ & $\begin{array}{l}\text { D } \\
\text { M } \\
( \\
\mathbf{G} \\
\text { a) }\end{array}$ \\
\hline \multirow{9}{*}{ 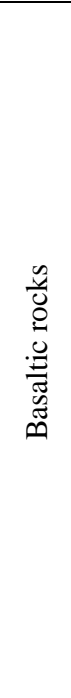 } & 301 & $\begin{array}{c}43 . \\
7\end{array}$ & $\begin{array}{c}67 \\
5.0\end{array}$ & $\begin{array}{c}0.18 \\
7248\end{array}$ & $\begin{array}{l}0.70 \\
4130\end{array}$ & 11 & $\begin{array}{c}0.704 \\
013\end{array}$ & $\begin{array}{c}4.2 \\
1\end{array}$ & $\begin{array}{c}19 . \\
7\end{array}$ & $\begin{array}{c}0.129 \\
204\end{array}$ & $\begin{array}{c}0.512 \\
772\end{array}$ & 5 & $\begin{array}{c}0.5127 \\
34\end{array}$ & $\begin{array}{c}2.6 \\
0\end{array}$ & $\begin{array}{c}2.6 \\
4\end{array}$ & $\begin{array}{l}0 . \\
68\end{array}$ \\
\hline & 363 & $\begin{array}{c}45 . \\
8\end{array}$ & $\begin{array}{l}46 \\
5.4\end{array}$ & $\begin{array}{l}0.28 \\
4628\end{array}$ & $\begin{array}{c}0.70 \\
4112\end{array}$ & 10 & $\begin{array}{c}0.703 \\
933\end{array}$ & $\begin{array}{c}3.5 \\
4\end{array}$ & $\begin{array}{c}14 . \\
4\end{array}$ & $\begin{array}{c}0.148 \\
630\end{array}$ & $\begin{array}{c}0.512 \\
813\end{array}$ & 5 & $\begin{array}{c}0.5127 \\
70\end{array}$ & $\begin{array}{c}3.4 \\
2\end{array}$ & $\begin{array}{c}3.4 \\
5\end{array}$ & $\begin{array}{l}0 . \\
79\end{array}$ \\
\hline & 141 & $\begin{array}{c}79 . \\
6\end{array}$ & $\begin{array}{c}67 \\
0.8\end{array}$ & $\begin{array}{r}0.34 \\
3221\end{array}$ & $\begin{array}{c}0.70 \\
4479\end{array}$ & 10 & $\begin{array}{c}0.704 \\
261\end{array}$ & $\begin{array}{c}4.2 \\
7\end{array}$ & $\begin{array}{c}21 . \\
3\end{array}$ & $\begin{array}{c}0.121 \\
201\end{array}$ & $\begin{array}{c}0.512 \\
738\end{array}$ & 5 & $\begin{array}{c}0.5127 \\
03\end{array}$ & $\begin{array}{c}1.9 \\
6\end{array}$ & $\begin{array}{c}2.0 \\
0\end{array}$ & $\begin{array}{l}0 . \\
68\end{array}$ \\
\hline & 260 & $\begin{array}{c}96 . \\
0\end{array}$ & $\begin{array}{l}93 \\
5.6\end{array}$ & $\begin{array}{l}0.29 \\
6776\end{array}$ & $\begin{array}{c}0.70 \\
4330\end{array}$ & 10 & $\begin{array}{c}0.704 \\
144\end{array}$ & $\begin{array}{c}5.6 \\
1\end{array}$ & $\begin{array}{c}26 . \\
0\end{array}$ & $\begin{array}{c}0.130 \\
452\end{array}$ & $\begin{array}{c}0.512 \\
764\end{array}$ & & $\begin{array}{c}0.5127 \\
26\end{array}$ & $\begin{array}{c}2.4 \\
5\end{array}$ & $\begin{array}{c}2.4 \\
9\end{array}$ & $\begin{array}{c}0 . \\
71\end{array}$ \\
\hline & 511 & $\begin{array}{c}81 . \\
4\end{array}$ & $\begin{array}{c}66 \\
5.5\end{array}$ & $\begin{array}{c}0.35 \\
3785\end{array}$ & $\begin{array}{l}0.70 \\
4705\end{array}$ & 10 & $\begin{array}{c}0.704 \\
480\end{array}$ & $\begin{array}{c}3.9 \\
1\end{array}$ & $\begin{array}{c}18 . \\
1\end{array}$ & $\begin{array}{c}0.130 \\
603\end{array}$ & $\begin{array}{c}0.512 \\
719\end{array}$ & & $\begin{array}{c}0.5126 \\
80\end{array}$ & $\begin{array}{c}1.5 \\
7\end{array}$ & $\begin{array}{c}1.6 \\
1\end{array}$ & $\begin{array}{l}0 . \\
79\end{array}$ \\
\hline & 399 & $\begin{array}{c}11 \\
0.1\end{array}$ & $\begin{array}{c}11 \\
90 . \\
6\end{array}$ & $\begin{array}{l}0.26 \\
7465\end{array}$ & $\begin{array}{l}0.70 \\
4294\end{array}$ & 9 & $\begin{array}{c}0.704 \\
130\end{array}$ & $\begin{array}{c}5.4 \\
2\end{array}$ & $\begin{array}{c}25 . \\
1\end{array}$ & $\begin{array}{c}0.130 \\
553\end{array}$ & $\begin{array}{c}0.512 \\
764\end{array}$ & 5 & $\begin{array}{c}0.5127 \\
27\end{array}$ & $\begin{array}{c}2.4 \\
6\end{array}$ & $\begin{array}{c}2.4 \\
9\end{array}$ & $\begin{array}{c}0 . \\
71\end{array}$ \\
\hline & 642 & $\begin{array}{c}39 . \\
3\end{array}$ & $\begin{array}{l}77 \\
6.4\end{array}$ & $\begin{array}{l}0.14 \\
6400\end{array}$ & $\begin{array}{l}0.70 \\
3987\end{array}$ & 10 & $\begin{array}{c}0.703 \\
893\end{array}$ & $\begin{array}{c}4.7 \\
5\end{array}$ & $\begin{array}{c}24 . \\
1\end{array}$ & $\begin{array}{c}0.119 \\
163\end{array}$ & $\begin{array}{c}0.512 \\
821\end{array}$ & 5 & $\begin{array}{c}0.5127 \\
86\end{array}$ & $\begin{array}{c}3.5 \\
6\end{array}$ & $\begin{array}{c}3.6 \\
1\end{array}$ & $\begin{array}{l}0 . \\
53\end{array}$ \\
\hline & 508 & $\begin{array}{l}14 \\
1.1\end{array}$ & $\begin{array}{l}49 \\
4.9\end{array}$ & $\begin{array}{c}0.82 \\
4666\end{array}$ & $\begin{array}{c}0.70 \\
4818\end{array}$ & 10 & $\begin{array}{c}0.704 \\
287\end{array}$ & $\begin{array}{c}5.7 \\
9\end{array}$ & $\begin{array}{c}29 . \\
9\end{array}$ & $\begin{array}{c}0.117 \\
075\end{array}$ & $\begin{array}{c}0.512 \\
731\end{array}$ & 5 & $\begin{array}{c}0.5126 \\
96\end{array}$ & $\begin{array}{c}1.8 \\
1\end{array}$ & $\begin{array}{c}1.8 \\
5\end{array}$ & $\begin{array}{l}0 . \\
66\end{array}$ \\
\hline & 801 & $\begin{array}{c}93 . \\
8 \\
\end{array}$ & $\begin{array}{r}63 \\
4.9 \\
\end{array}$ & $\begin{array}{c}0.42 \\
7323 \\
\end{array}$ & $\begin{array}{r}0.70 \\
4587 \\
\end{array}$ & 10 & $\begin{array}{c}0.704 \\
315 \\
\end{array}$ & $\begin{array}{c}4.6 \\
8 \\
\end{array}$ & $\begin{array}{c}24 . \\
3 \\
\end{array}$ & $\begin{array}{c}0.116 \\
441 \\
\end{array}$ & $\begin{array}{c}0.512 \\
828 \\
\end{array}$ & 5 & $\begin{array}{c}0.5127 \\
94 \\
\end{array}$ & $\begin{array}{c}3.7 \\
0 \\
\end{array}$ & $\begin{array}{c}3.7 \\
5 \\
\end{array}$ & $\begin{array}{r}0 . \\
51 \\
\end{array}$ \\
\hline \multirow{8}{*}{ 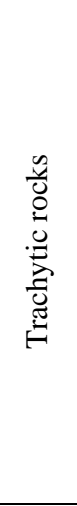 } & 232 & $\begin{array}{c}17 \\
0.8\end{array}$ & $\begin{array}{l}51 \\
0.0\end{array}$ & $\begin{array}{c}0.96 \\
8697\end{array}$ & $\begin{array}{c}0.70 \\
4857\end{array}$ & 9 & $\begin{array}{c}0.704 \\
253\end{array}$ & $\begin{array}{c}4.6 \\
5\end{array}$ & $\begin{array}{c}26 . \\
1\end{array}$ & $\begin{array}{c}0.107 \\
715\end{array}$ & $\begin{array}{c}0.512 \\
780\end{array}$ & 5 & $\begin{array}{c}0.5127 \\
49\end{array}$ & $\begin{array}{c}2.7 \\
6\end{array}$ & $\begin{array}{c}2.8 \\
1\end{array}$ & $\begin{array}{l}0 . \\
53\end{array}$ \\
\hline & 233 & $\begin{array}{l}17 \\
2.0\end{array}$ & $\begin{array}{l}46 \\
4.8\end{array}$ & $\begin{array}{l}1.07 \\
0371\end{array}$ & $\begin{array}{c}0.70 \\
4901\end{array}$ & 10 & $\begin{array}{c}0.704 \\
248\end{array}$ & $\begin{array}{c}4.2 \\
2\end{array}$ & $\begin{array}{c}22 . \\
2\end{array}$ & $\begin{array}{c}0.114 \\
926\end{array}$ & $\begin{array}{c}0.512 \\
734\end{array}$ & 4 & $\begin{array}{c}0.5127 \\
02\end{array}$ & $\begin{array}{c}1.8 \\
7\end{array}$ & $\begin{array}{c}1.9 \\
2\end{array}$ & $\begin{array}{l}0 . \\
64\end{array}$ \\
\hline & 777 & $\begin{array}{l}18 \\
1.7\end{array}$ & $\begin{array}{l}57 \\
4.8\end{array}$ & $\begin{array}{c}0.91 \\
4333\end{array}$ & $\begin{array}{c}0.70 \\
4768\end{array}$ & 10 & $\begin{array}{c}0.704 \\
198\end{array}$ & $\begin{array}{c}4.8 \\
0\end{array}$ & $\begin{array}{c}24 . \\
4\end{array}$ & $\begin{array}{c}0.118 \\
935\end{array}$ & $\begin{array}{c}0.512 \\
730\end{array}$ & 5 & $\begin{array}{c}0.5126 \\
96\end{array}$ & $\begin{array}{c}1.8 \\
0\end{array}$ & $\begin{array}{c}1.8 \\
4\end{array}$ & $\begin{array}{l}0 . \\
68\end{array}$ \\
\hline & 675 & $\begin{array}{l}12 \\
6.9\end{array}$ & $\begin{array}{r}63 \\
9.5\end{array}$ & $\begin{array}{c}0.57 \\
3957\end{array}$ & $\begin{array}{l}0.70 \\
4578\end{array}$ & 10 & $\begin{array}{c}0.704 \\
220\end{array}$ & $\begin{array}{c}4.5 \\
9\end{array}$ & $\begin{array}{c}22 . \\
6\end{array}$ & $\begin{array}{c}0.122 \\
790\end{array}$ & $\begin{array}{c}0.512 \\
749\end{array}$ & 5 & $\begin{array}{c}0.5127 \\
14\end{array}$ & $\begin{array}{c}2.1 \\
7\end{array}$ & $\begin{array}{c}2.2 \\
1\end{array}$ & $\begin{array}{l}0 . \\
67\end{array}$ \\
\hline & 188 & $\begin{array}{c}18 \\
9.8\end{array}$ & $\begin{array}{l}26 \\
1.1\end{array}$ & $\begin{array}{c}2.10 \\
2734\end{array}$ & $\begin{array}{l}0.70 \\
5440\end{array}$ & 10 & $\begin{array}{c}0.704 \\
206\end{array}$ & $\begin{array}{c}5.7 \\
4\end{array}$ & $\begin{array}{c}28 . \\
7\end{array}$ & $\begin{array}{c}0.120 \\
918\end{array}$ & $\begin{array}{c}0.512 \\
771\end{array}$ & 5 & $\begin{array}{c}0.5127 \\
38\end{array}$ & $\begin{array}{c}2.5 \\
9\end{array}$ & $\begin{array}{c}2.6 \\
3\end{array}$ & $\begin{array}{l}0 . \\
62\end{array}$ \\
\hline & 318 & 12 & 65 & 0.56 & 0.70 & & 0.704 & 5.9 & 29. & 0.121 & 0.512 & 5 & 0.5127 & 2.2 & 2.2 & 0. \\
\hline & 318 & 6.4 & 0.5 & 2020 & 4428 & & 079 & 3 & 6 & 122 & 753 & 5 & 18 & 4 & 8 & 65 \\
\hline & 625 & $\begin{array}{l}28 \\
4.0\end{array}$ & $\begin{array}{l}15 \\
4.7\end{array}$ & $\begin{array}{c}5.31 \\
1462\end{array}$ & $\begin{array}{c}0.70 \\
7564\end{array}$ & 10 & $\begin{array}{c}0.704 \\
252\end{array}$ & $\begin{array}{c}5.1 \\
6\end{array}$ & $\begin{array}{c}27 . \\
2\end{array}$ & $\begin{array}{c}0.114 \\
694\end{array}$ & $\begin{array}{c}0.512 \\
743\end{array}$ & 5 & $\begin{array}{c}0.5127 \\
10\end{array}$ & $\begin{array}{c}2.0 \\
4\end{array}$ & $\begin{array}{c}2.0 \\
9\end{array}$ & $\begin{array}{l}0 . \\
63\end{array}$ \\
\hline \multirow{3}{*}{ 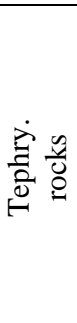 } & 603 & $\begin{array}{c}25 . \\
0\end{array}$ & $\begin{array}{c}22 \\
72 . \\
1\end{array}$ & $\begin{array}{c}0.03 \\
1827\end{array}$ & $\begin{array}{l}0.70 \\
5309\end{array}$ & 10 & $\begin{array}{c}0.705 \\
306\end{array}$ & $\begin{array}{l}12 . \\
30\end{array}$ & $\begin{array}{c}93 . \\
0\end{array}$ & $\begin{array}{c}0.079 \\
960\end{array}$ & $\begin{array}{c}0.512 \\
669\end{array}$ & 5 & $\begin{array}{c}0.5126 \\
66\end{array}$ & $\begin{array}{c}0.6 \\
0\end{array}$ & $\begin{array}{c}0.6 \\
1\end{array}$ & $\begin{array}{l}0 . \\
55\end{array}$ \\
\hline & 721 & $\begin{array}{c}78 . \\
9\end{array}$ & $\begin{array}{c}22 \\
71 . \\
8\end{array}$ & $\begin{array}{c}0.10 \\
0461\end{array}$ & $\begin{array}{l}0.70 \\
5371\end{array}$ & 10 & $\begin{array}{c}0.705 \\
362\end{array}$ & $\begin{array}{l}13 . \\
42\end{array}$ & $\begin{array}{c}87 . \\
4\end{array}$ & $\begin{array}{c}0.092 \\
831\end{array}$ & $\begin{array}{c}0.512 \\
693\end{array}$ & 5 & $\begin{array}{c}0.5126 \\
89\end{array}$ & $\begin{array}{c}1.0 \\
7\end{array}$ & $\begin{array}{c}1.0 \\
8\end{array}$ & $\begin{array}{c}0 . \\
58\end{array}$ \\
\hline & 726 & $\begin{array}{c}52 . \\
2\end{array}$ & $\begin{array}{c}31 \\
58 . \\
5\end{array}$ & $\begin{array}{l}0.04 \\
7805\end{array}$ & $\begin{array}{l}0.70 \\
5182\end{array}$ & 10 & $\begin{array}{c}0.705 \\
178\end{array}$ & $\begin{array}{l}11 . \\
32\end{array}$ & $\begin{array}{c}76 . \\
5\end{array}$ & $\begin{array}{c}0.089 \\
462\end{array}$ & $\begin{array}{c}0.512 \\
682\end{array}$ & 5 & $\begin{array}{c}0.5126 \\
78\end{array}$ & $\begin{array}{c}0.8 \\
5\end{array}$ & $\begin{array}{c}0.8 \\
6\end{array}$ & $\begin{array}{l}0 . \\
58\end{array}$ \\
\hline
\end{tabular}

Uncertainties for the ${ }^{87} \mathrm{Sr} /{ }^{86} \mathrm{Sr}$ and ${ }^{143} \mathrm{Nd} /{ }^{144} \mathrm{Nd}$ ratios are $2 \sigma_{\mathrm{m}}$ errors in the last two digits (in parentheses). $\varepsilon \mathrm{Nd}(0)$ and $\varepsilon N d(t)$ values are calculated relative to CHUR with present-day values of ${ }^{143} \mathrm{Nd} /{ }^{144} \mathrm{Nd}=0.512638$ and ${ }^{147} \mathrm{Sm} /{ }^{144} \mathrm{Nd}=0.1967$ (Jacobsen and Wasserburg, 1980). Nd single stage model ages $\left(T_{\mathrm{DM}}\right)$ are calculated with a depleted mantle reservoir and present-day values of ${ }^{143} \mathrm{Nd} /{ }^{144} \mathrm{Nd}=0.513151$ and ${ }^{147} \mathrm{Sm} /{ }^{144} \mathrm{Nd}=0.219$ (Liew and Hofmann, 1988). 
Table 3

\begin{tabular}{|c|c|c|c|c|c|c|c|}
\hline & Sample & $\mathrm{Pb}(\mathbf{p p m})$ & ${ }^{206} \mathrm{~Pb} /{ }^{204} \mathrm{~Pb}$ & ${ }^{207} \mathrm{~Pb} /{ }^{204} \mathrm{~Pb}$ & ${ }^{208} \mathrm{~Pb} /{ }^{204} \mathrm{~Pb}$ & $\Delta 8 / 4$ & $\Delta 7 / 4$ \\
\hline \multirow{9}{*}{ 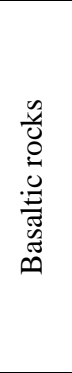 } & 301 & 5.7 & 18.752 & 15.632 & 38.837 & 53.883 & 10.828 \\
\hline & 363 & 3.4 & 18.724 & 15.638 & 38.827 & 56.268 & 11.732 \\
\hline & 141 & 5.9 & 18.745 & 15.647 & 38.863 & 57.329 & 12.404 \\
\hline & 260 & 4.6 & 18.775 & 15.633 & 38.854 & 52.803 & 10.679 \\
\hline & 511 & 3.3 & 18.722 & 15.630 & 38.786 & 52.410 & 10.954 \\
\hline & 399 & 13.7 & 18.786 & 15.658 & 38.923 & 58.373 & 13.060 \\
\hline & 642 & 3.5 & 18.756 & 15.641 & 38.878 & 57.500 & 11.685 \\
\hline & 508 & 9.2 & 18.737 & 15.669 & 38.913 & 63.297 & 14.691 \\
\hline & 801 & 11.8 & 18.773 & 15.641 & 38.868 & 54.444 & 11.501 \\
\hline \multirow{7}{*}{ 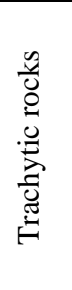 } & 232 & 2.9 & 18.795 & 15.639 & 38.882 & 53.184 & 11.062 \\
\hline & 233 & 3.9 & 18.819 & 15.658 & 38.968 & 58.883 & 12.702 \\
\hline & 777 & 31.3 & 18.788 & 15.638 & 38.867 & 52.531 & 11.038 \\
\hline & 675 & 26.3 & 18.797 & 15.648 & 38.904 & 55.143 & 11.941 \\
\hline & 188 & 29.3 & 18.776 & 15.644 & 38.872 & 54.482 & 11.768 \\
\hline & 318 & 8.4 & 18.778 & 15.671 & 38.951 & 62.140 & 14.446 \\
\hline & 625 & 17.4 & 18.780 & 15.643 & 38.891 & 55.898 & 11.625 \\
\hline \multirow{3}{*}{ 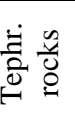 } & 603 & 30.7 & 18.893 & 15.669 & 38.938 & 46.936 & 13.000 \\
\hline & 721 & 17.1 & 18.946 & 15.680 & 39.058 & 52.529 & 13.525 \\
\hline & 726 & 20.1 & 18.929 & 15.661 & 39.025 & 51.284 & 11.810 \\
\hline
\end{tabular}

$\left.\left.\left.\Delta 8 / 4 \mathrm{~Pb}=100 \times\left[{ }^{208} \mathrm{~Pb} /{ }^{204} \mathrm{~Pb}\right)-1.209 \times{ }^{206} \mathrm{~Pb} /{ }^{204} \mathrm{~Pb}\right)-15.627\right] . \Delta 7 / 4 \mathrm{~Pb}=100 \times\left[{ }^{207} \mathrm{~Pb} /{ }^{204} \mathrm{~Pb}\right)-0.1084 \mathrm{x}\left({ }^{206} \mathrm{~Pb} /{ }^{204} \mathrm{~Pb}\right)-13.491\right]$ (Hart, 1984). 
Table 4.

\begin{tabular}{llcccccc}
\hline $\begin{array}{l}\text { Magma } \\
\text { Composition }\end{array}$ & Elements & Amphibole & Plagioclase & Clinopyroxene & Olivine & Biotite & Sanidine \\
\hline \multirow{3}{*}{ Basic } & $\mathrm{Rb}$ & 0.1 & 0.05 & 0.035 & 0.002 & 2.5 & 0.01 \\
\cline { 2 - 8 } & $\mathrm{Sc}$ & 2.2 & 0.0008 & 3.2 & 0.17 & - & - \\
\cline { 2 - 8 } & $\mathrm{Sr}$ & 0.45 & 1.2 & 0.06 & 0.015 & - & - \\
\cline { 2 - 8 } Intermediate & $\mathrm{Nb}$ & 0.3 & 0.01 & 0.04 & 0.01 & - & - \\
\hline
\end{tabular}

$\mathrm{Kd}$ values of $\mathrm{Rb}, \mathrm{Sc}, \mathrm{Sr}, \mathrm{Nb}$, Dy and $\mathrm{Sr}$ for amphibole, plagioclase, clinopyroxene, olivine, biotite and sanidine were compiled from Rollinson (1993), GERM Partition Coefficient (Kd) Database of Earth Reference Data and Models website (http://earthref.org/; see the references therein) and Keskin (2002). 
Table 5.

\begin{tabular}{|c|c|c|c|c|c|c|c|c|}
\hline \multirow{2}{*}{$\begin{array}{l}\text { End } \\
\text { member }\end{array}$} & \multirow{2}{*}{$\begin{array}{c}\mathrm{IC}_{0} \\
\text { (parental magma) }\end{array}$} & \multirow{2}{*}{$\begin{array}{c}\mathrm{IC}_{\mathrm{A}} \\
\text { (local continental } \\
\text { crust) }\end{array}$} & \multirow{2}{*}{$\begin{array}{c}\mathrm{IC}_{\mathrm{A}} \\
\text { (continental crust) }\end{array}$} & \multicolumn{5}{|c|}{ Total Partition coefficient $\left(\sum D\right)$} \\
\hline & & & & & D1 & D2 & D3 & D4 \\
\hline $\mathrm{Sr}(\mathrm{ppm})$ & 887.2 & 59.1 & 386 & $\mathrm{Sr}$ & 1.60 & 1.20 & 1.20 & 0.15 \\
\hline $\mathrm{Nd}(\mathrm{ppm})$ & 34.5 & 23.1 & 3.85 & $\mathrm{Nd}$ & 0.95 & 1.15 & 1.85 & 2.00 \\
\hline Sample no: & K-93-56 & T135 (granite) & ERN-57 (limestone) & \multirow{3}{*}{\multicolumn{5}{|c|}{$\begin{array}{l}\text { For all continental crust } \\
\text { modelling }\end{array}$}} \\
\hline${ }^{87} \mathrm{Sr} /{ }^{86} \mathrm{Sr}$ & 0.703114 & 0.728225 & 0.708768 & & & & & \\
\hline \multirow[t]{2}{*}{${ }^{143} \mathrm{Nd} /{ }^{144} \mathrm{Nd}$} & 0.512941 & 0.512121 & 0.512115 & & & & & \\
\hline & Alıc1 et al. (2002) & Kaygusuz et al. (2012) & Boari et al. (2009) & & & & & \\
\hline
\end{tabular}


Table 6.

\begin{tabular}{|c|c|c|c|}
\hline Mantle Sources & \multicolumn{2}{|c|}{ Modal proportions } & Normative weight fractions of minerals (i) in the partial melts \\
\hline Garnet lherzolite & \multicolumn{2}{|c|}{$\mathrm{Ol}_{0.598} \mathrm{Opir}_{0.211} \mathrm{Kpir}_{0.076} \mathrm{Grt}_{0.115}$} & $\mathrm{Ol}_{0.05} \mathrm{Opx}_{0.2} \mathrm{Cpx}_{0.3} \mathrm{Grt}_{0.45}$ \\
\hline Spinel lherzolite & \multicolumn{2}{|c|}{$\mathrm{Ol}_{0.578} \mathrm{Opir}_{0.27} \mathrm{Kpir}_{0.119} \mathrm{Spl}_{0.033}$} & $\mathrm{Ol}_{0.1} \mathrm{Opx}_{0.27} \mathrm{Cpx}_{0.5} \mathrm{Spl}_{0.13}$ \\
\hline Partition coefficients & $D_{\mathrm{La}}$ & $D_{\mathrm{Yb}}$ & \multirow{2}{*}{$\begin{array}{l}\text { Partition coefficient }(D) \text { values are from Keskin (1994), McKenzie } \\
\text { and O'Nions }(1991,1995) \text { and GERM (Geochemical Earth } \\
\text { Reference Model) website. at http://earthref.org/databases/KDD/ }\end{array}$} \\
\hline Olivine & 0.0004 & 0.0015 & \\
\hline Orthopyroxene & 0.002 & 0.049 & \multirow{2}{*}{$\begin{array}{l}\text { Source compositions: Primitive mantle REE composition } \\
\text { (McDonough and Sun, 1995) was chosen for all partial melting } \\
\text { scenarios }\end{array}$} \\
\hline Clinopyroxene & 0.0435 & 0.313 & \\
\hline Garnet & 0.01 & 4.3 & $\begin{array}{l}\text { Ol: olivine. Opx: orthopyroxene. Cpx: clinopyroxene. Grt: garnet. } \\
\text { Spl: spinel }\end{array}$ \\
\hline Spinel & 0.01 & 0.01 & $\begin{array}{l}\text { Garnet and spinel lherzolite composition are from Thirlwall et al. } \\
\text { (1994) }\end{array}$ \\
\hline
\end{tabular}


Table 7

\begin{tabular}{lcccccccc}
\hline & $\begin{array}{c}\mathbf{S r} \\
(\mathbf{p p m})\end{array}$ & ${ }^{87} \mathbf{S r} /{ }^{\mathbf{8 6}} \mathbf{S r}$ & $\begin{array}{c}\mathbf{N d} \\
(\mathbf{p p m})\end{array}$ & $\boldsymbol{\varepsilon} \mathbf{N d}$ & $\mathbf{P b}(\mathbf{p p m})$ & ${ }^{{ }^{206} \mathbf{P b} /{ }^{204} \mathbf{P b}}$ & ${ }^{{ }^{207} \mathbf{P b} /{ }^{\mathbf{2 0 4}} \mathbf{P b}}$ & ${ }^{{ }^{208} \mathbf{P b} /{ }^{\mathbf{2 0 4}} \mathbf{P b}}$ \\
\hline UM & 20 & 0.703 & 1.2 & 8 & 0.185 & 18 & 15.6 & 38.7 \\
Lower Crust & 300 & 0.710 & 24 & -30 & 4.2 & 15.518 & 15.117 & 4.2 \\
Upper Crust & 59.1 & 0.72823 & 23.1 & -9.36 & 7.3 & 19.09 & 15.67 & 39.12 \\
\hline
\end{tabular}

UM stands for upper mantle peridotite. $\mathrm{Sr}-\mathrm{Nd}$ data of UM are from Jahn et al. (1999); Pb data are from Sun and McDonough (1989). Sr-Nd data of lower crust are from Xu et al. (2004) and Jahn et al. (1999); Pb isotopic composition is from Zhang (1995). Pb concentration is from Rudnick and Fountain (1995). Sr-Nd-Pb isotope data and $\mathrm{Pb}$ concentration of upper crust are from (T135, Carboniferous aged granite; Kaygusuz et al. 2012). 


\section{GRAPHICAL ABSTRACT}

\section{Eocene Volcanism}

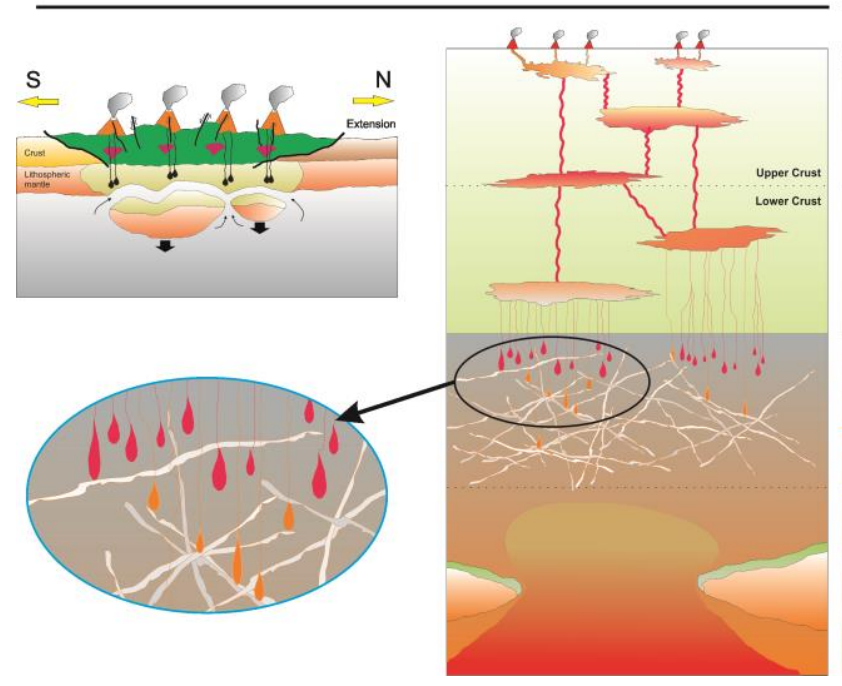

Miocene Volcanism
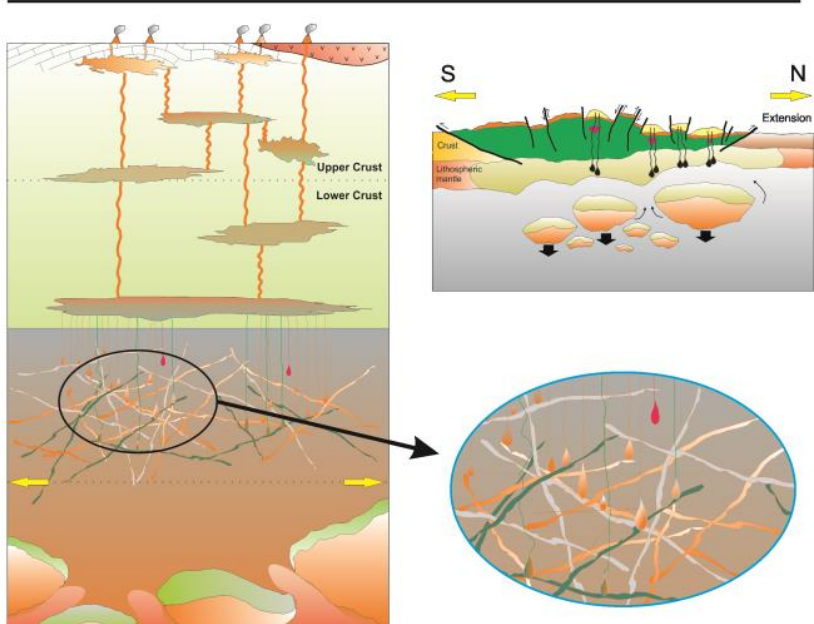


\section{HIGHLIGHTS}

- Eocene volcanism is widespread, while the Miocene volcanism is cover limited area in the Eastern Pontides (NE Turkey)

- We report new whole-rock geochemical, $\mathrm{Sr}-\mathrm{Nd}-\mathrm{Pb}$ isotopic and ${ }^{40} \mathrm{Ar}-{ }^{39} \mathrm{Ar}$ dating data

- Carbonate assimilation contributes Si-undersatured characteristic of Miocene volcanism

- Potassic parental melts have been derived from net veined lithospheric mantle

- Strike-slip faults may lead to pathway for the Miocene volcanism 